\title{
Engineering Biological C-H Functionalization Leads to Allele-Specific Regulation of Histone Demethylases
}

\author{
Megan Breski, ${ }^{\S} \rrbracket$ Debasis Dey, ${ }^{\S}$ Sara Obringer, ${ }^{\S}$ Babu Sudhamalla, ${ }^{\S}$ Kabirul Islam* ${ }^{*} \S$ \\ $\S$ Department of Chemistry, "Department of Human Genetics, University of \\ Pittsburgh, Pittsburgh PA 15260
}

\section{Supporting Material}

1. General materials, methods and equipment $\quad \mathrm{S} 2$

2. Synthesis and of $2 \mathrm{KG}$ and $2 \mathrm{HG}$ analogues $\mathrm{S} 3$

3. Characterization of $2 \mathrm{KG}$ an $2 \mathrm{HG}$ analogues S5

4. Synthesis and purification of peptides $\quad$ S11

5. Synthesis and purification of oligonucleotides $\quad \mathrm{S} 12$

6. Mutagenesis, expression and purification of 2KG-dependent oxygenases $\quad$ S13

7. Expression and purification of Formaldehyde Dehydrogenase (FDH) S15

8. MALDI demethylase activity assay $\quad$ S16

$\begin{array}{ll}\text { 9. Coupled fluorescence assay } & \text { S17 }\end{array}$

$\begin{array}{ll}\text { 10. NADH calibration curve } & \text { S17 }\end{array}$

11. Expression and purification of histone $\mathrm{H} 3$ and its mutants $\quad \mathrm{S} 18$

12. Chemical trimethylation of $\mathrm{H}_{3} \mathrm{~K}_{\mathrm{C}} 9 \quad \mathrm{~S} 19$

13. Demethylase activity assay on $\mathrm{H}_{3} \mathrm{~K}_{\mathrm{C}} 9 \mathrm{Me}_{3} \quad \mathrm{~S} 19$

$\begin{array}{lr}\text { 14. Demethylase activity assay on calf histones } & \text { S20 }\end{array}$

15. Mammalian cell culture and cell lysis $\quad \mathrm{S} 20$

16. Demethylase activity assay in HEK293T cell lysates $\quad$ S20

$\begin{array}{ll}\text { 17. Western blotting } & \text { S21 }\end{array}$

18. LC-MS analysis $\quad$ S21

19. Supplementary figures and tables $\quad$ S23

20. References $\quad$ S62 


\section{General materials, methods and equipments}

Chemicals: All chemicals were purchased from established vendors (e.g. Sigma-Aldrich, Acros Organics) and used without purification unless otherwise noted. Optima grade acetonitrile was obtained from Fisher Scientific and degassed under vacuum prior to HPLC purification. All reactions to prepare analogues of $2 \mathrm{KG}$ and $2 \mathrm{HG}$ were carried out in round bottom flasks and stirred with Teflon ${ }^{\circledR}$-coated magnetic stir bars under inert atmosphere when needed. Analytical thin layer chromatography (TLC) was performed using EMD 250 micron flexible aluminum backed, UV $\mathrm{F}_{254}$ pre-coated silica gel plates and visualized under UV light (254 nm) or by staining with phosphomolybdic acid, ninhydrin or anisaldehyde. Reaction solvents were removed by a Büchi rotary evaporator equipped with a dry ice-acetone condenser. Analytic and preparative HPLC was carried out on an Agilent 1220 Infinity HPLC with diode array detector. Concentration and lyophilization of aqueous samples were performed using Savant Sc210A SpeedVac Concentrator (Thermo), followed by Labconco Freeze-Dryer system.

Proton nuclear magnetic resonance spectra (1H NMR) were recorded on Bruker Ultrashield ${ }^{\mathrm{TM}}$ Plus $600 / 500 / 400 / 300 \mathrm{MHz}$ instruments at $24{ }^{\circ} \mathrm{C}$. Chemical shifts of ${ }^{1} \mathrm{H}$ and ${ }^{13} \mathrm{C}$ NMR spectra are reported as $\delta$ in units of parts per million (ppm) relative to tetramethylsilane $(\delta 0.0)$ or residual solvent signals: chloroform-d $\left(\delta 7.26\right.$, singlet), methanol- $\mathrm{d}_{4}$ ( $\delta 3.30$, quintet), and deuterium oxide- $\mathrm{d}_{2}(\delta 4.80$, singlet). Coupling constants are expressed in Hz. Mass spectra were collected at the UPITT MASSSPEC lab on a Q-Exactive ${ }^{\mathrm{TM}}$ Thermo Scientific LC-MS with electron spray ionization (ESI) probe.

Plasmids, mutagenic primers, cell lines and antibodies: All the plasmids are for bacterial expression and obtained as gifts from individual laboratories or purchased from Addgene. Details of these constructs are given in Table S1. Mutagenic primers are obtained from Integrated DNA Technologies (Table S2). Competent bacterial cells used for protein expression and mutagenesis are given in Table S3. Human embryonic kidney 293T (HEK293T) cells, obtained from the American Type Culture Collection (ATCC) and used in the current study following manufacturer's protocol (details in section 15). All the antibodies used in the current study are purchased from established vendors and used following manufacturer's protocol (details in section 17). 


\section{Synthesis of $2 \mathrm{KG}$ and $2 \mathrm{HG}$ analogues}

We have synthesized $2 \mathrm{KG}$ and $2 \mathrm{HG}$ analogues as shown in Scheme S1 and S2 respectively by modifying a reported method. ${ }^{1}$ Our synthesis, commenced from $2 \mathrm{KG} \mathrm{1}$, involved primarily a protection of the carboxylic and 2-oxo groups present in $\mathbf{1}$, an $\mathrm{S}_{\mathrm{N}} 2$-mediated alkylation, catalytic hydrogenation of the side chains (for 4-8) followed by a global deprotection and HPLC purification (Scheme S1). Rational in using an unsaturated side chain was to facilitate the alkylation step by lowering the transition state barrier through $p-\pi^{*}$ delocalization (Scheme S1).

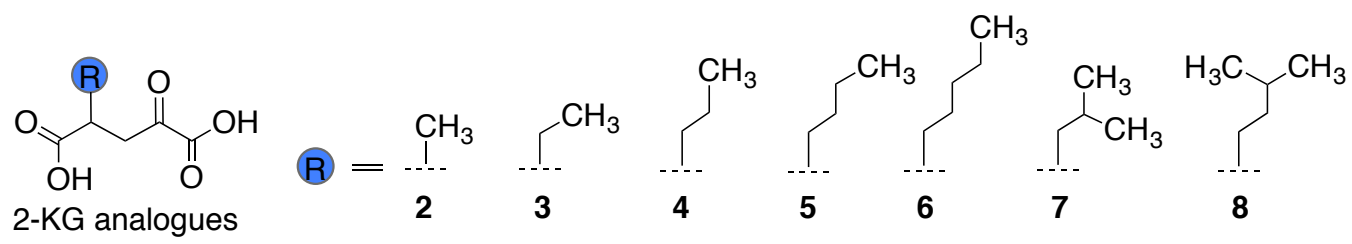<smiles>COC(=O)CCC(OC)(OC)C(=O)OC</smiles><smiles>[R8]C([R3])=C([R3])CBr</smiles>

Scheme S1: Structures and synthesis of "bumped" 2KG analogues. Compounds 2 and 3 were synthesized using methyl- and ethyl iodide as electrophiles (RX). For analogues 4-8, alkylation reactions were performed using corresponding unsaturated bromides. In the proposed linear transition state, the $\mathrm{sp}^{3}$-hybridized methylene carbon is rehybridized to $\mathrm{sp}^{2}$ and the incipient $p$ orbital is stabilized through delocalization with adjacent antibonding $\pi$ orbitals, facilitating the $S_{N} 2$ reaction. $R_{1}, R_{2}, R_{3}$ are hydrogen, methylene or alkyl groups depending on the final compounds.

\section{General method for alkylation step:}

To a stirred and cooled $\left(-78^{\circ} \mathrm{C}\right)$ solution of 2-ketoglutaric acid dimethyl ester $(1.0 \mathrm{~g}, 4.54 \mathrm{mmol}$, 1 equiv.) in THF was added LiHMDS (5.45 mL, $5.45 \mathrm{mmol}, 1.2$ equiv, $1 \mathrm{M}$ solution in THF) drop wise over a period of $10 \mathrm{~min}$. The reaction mixture was stirred at that temperature for $1 \mathrm{~h}$. 
After which alkyl halide (5.45 mmol, 1.2 equiv.) was added drop wise. The reaction mixture was kept stirring overnight while allowed to increase to ambient temperature. The reaction was quenched with $10 \mathrm{~mL}$ of aqueous saturated $\mathrm{NH}_{4} \mathrm{Cl}$ solution. The mixture was extracted with EtOAc $(3 \times 20 \mathrm{~mL})$. The organic layers were combined and dried with $\mathrm{Na}_{2} \mathrm{SO}_{4}$ and concentrated under reduced pressure. The crude product was purified by flash chromatography using EtOAchexanes solvent system generally in the range of $1: 9$ to $2: 8$.

\section{General method for hydrogenation:}

To a stirring solution of fully protected and alkylated compound in $4 \mathrm{~mL}$ ethyl acetate was added $\mathrm{Pd} / \mathrm{C}(10 \mathrm{~mol} \% \mathrm{Pd})$. The reaction mixture was degassed under vacuum, connected to hydrogen balloon and stirred at room temperature overnight. The reaction mixture was filtered through celite and concentrated in vacuo. The crude compound was purified by flash chromatography using EtOAc-hexanes solvent system generally with an isocratic gradient of 1:8. The product was subsequently subjected to deketalization as described below.

\section{General method for deketalization:}

To a stirring solution of fully protected and alkylated compound in $1 \mathrm{~mL}$ dichloromethane was added $0.1 \mathrm{~mL}$ water followed by $1 \mathrm{~mL}$ trifluoroacetic acid. The reaction mixture was stirred for 2 hr. at room temperature. The reaction mixture was concentrated in vacuo and the crude compound was purified by flash chromatography using EtOAc-hexanes solvent system generally with an isocratic gradient of 1:5.

\section{General method for ester hydrolysis:}

To a stirring solution of dimethyl ester of $2 \mathrm{KG}$ analogues $\left(0.2 \mathrm{mmol}, 1.0\right.$ equiv.) in $\mathrm{MeOH}: \mathrm{H}_{2} \mathrm{O}$ (1.2 mL : $0.8 \mathrm{~mL})$ was added $\mathrm{LiOH}(0.012 \mathrm{~g}, 0.5 \mathrm{mmol}, 2.5$ equiv.). The mixture was stirred at room temperature for $2 \mathrm{hr}$. A TLC at this stage indicated complete consumption of the starting dimethyl ester. The reaction was quenched by addition of $1 \mathrm{M} \mathrm{HCl}$ until $\mathrm{pH}$ paper indicated neutral. The mixture was partially evaporated under reduced pressure to remove methanol, diluted with $1 \mathrm{~mL}$ of water and filtered through $0.2 \mu \mathrm{M}$ filter and purified through HPLC using a C-18 column (Solvent A: water Solvent B: Acetonitrile; gradient 0 min 5\% B, 20 min 50\% B, 
$25 \mathrm{~min} 95 \% \mathrm{~B}$, flow rate $4 \mathrm{~mL} / \mathrm{min}$, wavelength $220 \mathrm{~nm}$ ). The fractions were collected and concentrated either in a speedvac concentrator or lyophilized to obtain targeted $2 \mathrm{KG}$ analogues.

\section{General method for 2-keto group reduction and hydrolysis with 4-ethyl-2-hydroxyl- glutaric acid 10 as a representative example:}

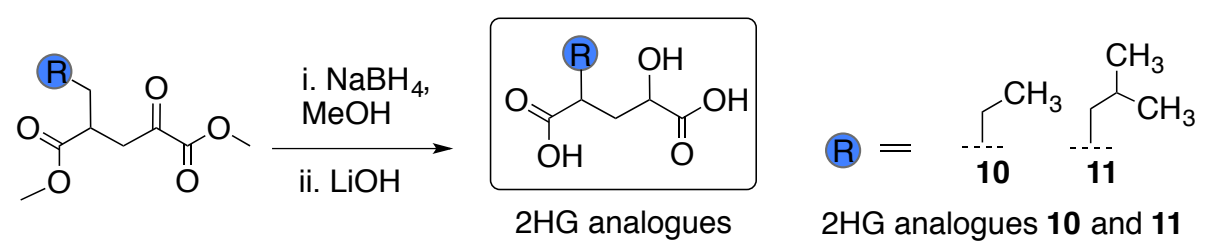

Scheme S2: Structures and synthesis of "bumped" $2 \mathrm{HG}$ analogues 10 and 11. 2 HG 9 was purchased from Sigma-Aldrich.

To a stirring solution of 4-ethyl-2-keto-glutaric acid dimethyl ester $(0.05 \mathrm{~g}, 0.247 \mathrm{mmol}, 1$ equiv.) in methanol (1.8 mL) was added $\mathrm{NaBH}_{4}(0.009 \mathrm{~g}, 0.247 \mathrm{mmol}, 1$ equiv.) (Scheme S2). The reaction mixture was stirred at room temperature for $10 \mathrm{~min}$. TLC revealed complete conversion of starting compound. The reaction was quenched by the addition of acetone $(20 \mu \mathrm{L})$ and stirred for additional $5 \mathrm{~min}$. Water $(0.4 \mathrm{~mL})$ was added followed by $\mathrm{LiOH}(0.015 \mathrm{~g}, 0.618$ mmol, 2.5 equiv.). Then the reaction was left stirring for 2 hours at room temperature. The reaction was quenched by the addition of $1 \mathrm{M} \mathrm{HCl}$ till $\mathrm{pH}$ paper indicated to be neutral.

The reaction mixture was partially evaporated to remove methanol and then $2 \mathrm{~mL}$ of water added and directly purified through HPLC using a C-18 column (Solvent A: water $+0.01 \%$ TFA, Solvent B: Acetonitrile; gradient $0 \min 5 \% \mathrm{~B}, 20 \min 50 \% \mathrm{~B}, 25 \min 95 \% \mathrm{~B}$, flow rate 4 $\mathrm{mL} / \mathrm{min}$, wavelength $220 \mathrm{~nm}$ ). The fractions were collected and concentrated either in a speedvac concentrator or lyophilized to get $\mathbf{1 0}(0.020 \mathrm{~g}, 46 \%$ yield in two steps) as amorphous solid.

\section{Characterization of $2 \mathrm{KG}$ and $2 \mathrm{HG}$ analogues}

\section{NMR data for 2KG 3 and $2 H G 10$ series:}




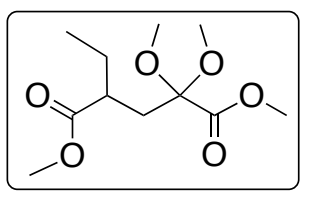

${ }^{1} H$ NMR (CHLOROFORM-d, 600MHz): $\delta=3.78(\mathrm{~s}, 3 \mathrm{H}), 3.65(\mathrm{~s}, 3 \mathrm{H}), 3.23$ (s, 3H), $3.22(\mathrm{~s}, 3 \mathrm{H}), 2.31-2.41(\mathrm{~m}, 2 \mathrm{H}), 1.90(\mathrm{dd}, J=13.7,2.4 \mathrm{~Hz}, 1 \mathrm{H})$, $1.54-1.62(\mathrm{~m}, 1 \mathrm{H}), 1.46-1.54(\mathrm{~m}, 1 \mathrm{H}), 0.86 \mathrm{ppm}(\mathrm{t}, J=7.3 \mathrm{~Hz}, 3 \mathrm{H})$

${ }^{13} \mathrm{C}$ NMR (CHLOROFORM-d, 150MHz): $\delta=175.8,169.2,101.6,52.5,51.5,49.9,41.7,35.4$, 26.6, $11.4 \mathrm{ppm}$

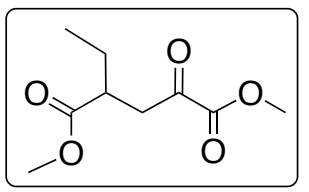

${ }^{1}$ H NMR (CHLOROFORM-d, 500MHz): $\delta=3.89(\mathrm{~s}, 3 \mathrm{H}), 3.70(\mathrm{~s}, 3 \mathrm{H}), 3.32$ $(\mathrm{dd}, J=19.5,10.3 \mathrm{~Hz}, 1 \mathrm{H}), 2.86-2.95(\mathrm{~m}, 2 \mathrm{H}), 1.68$ - 1.77 (m, 1H), 1.58 $1.68(\mathrm{~m}, 1 \mathrm{H}), 0.95(\mathrm{t}, J=7.5 \mathrm{~Hz}, 3 \mathrm{H}) \mathrm{ppm}$.

${ }^{13}$ C NMR (CHLOROFORM-d, 125MHz): $\delta=192.3,174.9,161.0,53.0,51.9,41.2,40.3,24.8$, $11.3 \mathrm{ppm}$.

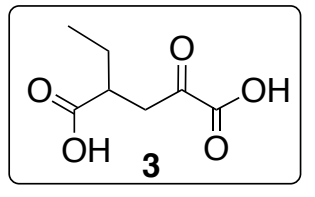

${ }^{1} H$ NMR (DEUTERIUM OXIDE, 600MHz): $\delta=2.96(\mathrm{dd}, J=18.4,8.7 \mathrm{~Hz}, 1$ H), $2.78(\mathrm{dd}, J=18.3,5.5 \mathrm{~Hz}, 1 \mathrm{H}), 2.48-2.54$ (m, 1H), 1.45 (q, J=7.3 Hz, 2 $\mathrm{H}), 0.82$ (t, $J=7.5 \mathrm{~Hz}, 3 \mathrm{H}) \mathrm{ppm}$.

${ }^{13}$ C NMR (DEUTERIUM OXIDE, 150MHz): $\delta=205.3,183.9,170.1,44.7,42.0,25.4,11.1 \mathrm{ppm}$. HRMS: Calculated for $\mathrm{C}_{7} \mathrm{H}_{9} \mathrm{O}_{5}[\mathrm{M}-\mathrm{H}]^{-}, 173.0445$; obtained 173.0444

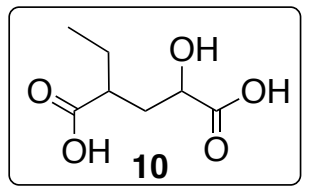

${ }^{1} H$ NMR (DEUTERIUM OXIDE, 600MHz): $\delta=3.97(\mathrm{~d}, J=6.8 \mathrm{~Hz}, 1 \mathrm{H}), 2.25$ - $2.35(\mathrm{~m}, 1 \mathrm{H}), 1.69$ - $1.82(\mathrm{~m}, 2 \mathrm{H}), 1.53$ - 1.64 (m, 2H), 1.38 - 1.50 (m, 2 $\mathrm{H}), 0.84-0.87(\mathrm{~m}, 4 \mathrm{H}) \mathrm{ppm}$.

${ }^{13}$ C NMR (DEUTERIUM OXIDE, 150MHz): $\delta=185.4,185.1,181.9,71.3,71.0,47.3,47.1,37.6$, $35.7,26.2,24.3,11.5,11.3 \mathrm{ppm}$.

HRMS: Calculated for $\mathrm{C}_{7} \mathrm{H}_{11} \mathrm{O}_{5}[\mathrm{M}-\mathrm{H}]^{-}, 175.0601$; obtained 175.0604

NMR data for 2KG 4 series:

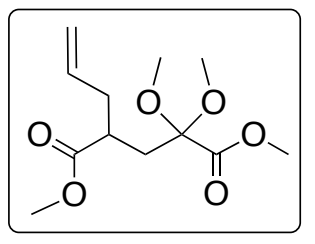

${ }^{1}$ H NMR (CHLOROFORM-d, 300MHz): $\delta=5.58-5.75(\mathrm{~m}, 1 \mathrm{H}), 5.04-5.09$ $(\mathrm{m}, 1 \mathrm{H}), 5.02(\mathrm{~s}, 1 \mathrm{H}), 3.75-3.79(\mathrm{~m}, 3 \mathrm{H}), 3.64(\mathrm{~s}, 3 \mathrm{H}), 3.23(\mathrm{~d}, J=2.1 \mathrm{~Hz}, 6$ H), $2.45-2.58(\mathrm{~m}, 1 \mathrm{H}), 2.28-2.42(\mathrm{~m}, 2 \mathrm{H}), 2.13-2.28(\mathrm{~m}, 1 \mathrm{H}), 1.94(\mathrm{dd}$, $J=14.5,3.0 \mathrm{~Hz}, 1 \mathrm{H}) \mathrm{ppm}$. 
${ }^{13} \mathrm{C}$ NMR (CHLOROFORM- $\left.d, 75 \mathrm{MHz}\right): \delta=175.2,169.1,134.5,117.7,101.5,52.4,51.6,50.0$, $49.9,40.1,37.5,34.9 \mathrm{ppm}$.

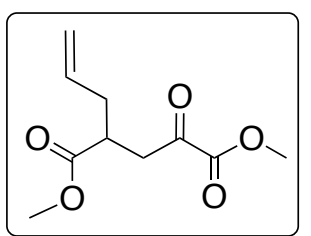

${ }^{1} H$ NMR (CHLOROFORM-d, 50OMHz): $\delta=5.70$ (ddt, $J=17.2,9.8,7.2 \mathrm{~Hz}, 1$ H), 5.09 - $5.11(\mathrm{~m}, 1 \mathrm{H}), 5.07(\mathrm{~s}, 1 \mathrm{H}), 3.87$ (s, 3H), 3.68 (s, 3H), 3.29 (dd, $J=18.8,9.3 \mathrm{~Hz}, 1 \mathrm{H}), 3.00-3.08$ (m, 1H), 2.92 (dd, $J=18.7,4.5 \mathrm{~Hz}, 1 \mathrm{H}), 2.43$ - $2.51(\mathrm{~m}, 1 \mathrm{H}), 2.32(\mathrm{dt}, J=14.3,7.6 \mathrm{~Hz}, 1 \mathrm{H}) \mathrm{ppm}$.

${ }^{13}$ C NMR (CHLOROFORM- $\left.d, 125 \mathrm{MHz}\right): \delta=192.2,174.3,160.9,134.2,118.2,53.1,52.1,39.8$, $39.6,35.7 \mathrm{ppm}$.

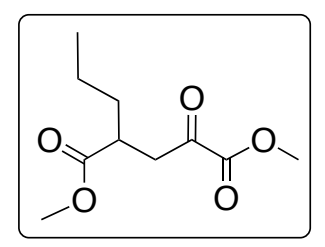

${ }^{1} H$ NMR (CHLOROFORM-d, 600MHz): $\delta=3.86(\mathrm{~s}, 3 \mathrm{H}), 3.66(\mathrm{~s}, 3 \mathrm{H}), 3.23$ - $3.33(\mathrm{~m}, 1 \mathrm{H}), 2.85-2.97(\mathrm{~m}, 2 \mathrm{H}), 1.60-1.68(\mathrm{~m}, 1 \mathrm{H}), 1.51(\mathrm{td}, J=14.4$, $7.3 \mathrm{~Hz}, 1 \mathrm{H}), 1.27-1.36(\mathrm{~m}, 2 \mathrm{H}), 0.90$ (t, $J=7.2 \mathrm{~Hz}, 4 \mathrm{H}) \mathrm{ppm}$.

${ }^{13} \mathrm{C} N M R$ (CHLOROFORM- $\left.d, 150 \mathrm{MHz}\right): \delta=192.3,175.2,160.9,53.0,51.9$, 40.6, 39.6, 33.8, 20.1, $13.7 \mathrm{ppm}$.

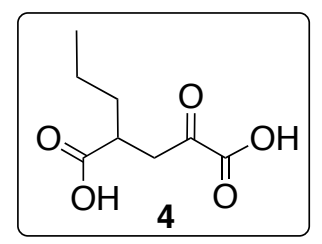

${ }^{1} H$ NMR (DEUTERIUM OXIDE, 400MHz): $\delta=2.89-2.99(\mathrm{~m}, 1 \mathrm{H}), 2.77$ (dd, $J=18.3,5.8 \mathrm{~Hz}, 1 \mathrm{H}), 2.58$ (tt, $J=8.3,6.0 \mathrm{~Hz}, 1 \mathrm{H}), 1.29-1.49$ (m, 2H), $1.16-1.27(\mathrm{~m}, 2 \mathrm{H}), 0.81(\mathrm{t}, J=7.3 \mathrm{~Hz}, 3 \mathrm{H}) \mathrm{ppm}$.

${ }^{13}$ C NMR (DEUTERIUM OXIDE, 100MHz): $\delta=205.2,184.1,170.1,43.0$, 42.3, 34.5, 20.0, $13.3 \mathrm{ppm}$.

HRMS: calculated for $\mathrm{C}_{8} \mathrm{H}_{11} \mathrm{O}_{5}[\mathrm{M}-\mathrm{H}]^{-}, 187.0610$; obtained 187.0600

\section{NMR data for 2KG 5 series:}

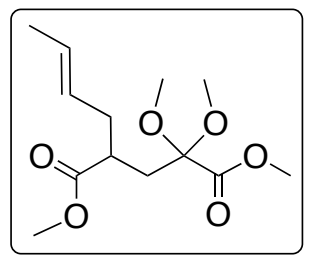

${ }^{1}$ H NMR (CHLOROFORM- $\left.d, 300 M H z\right): \delta=5.42-5.56(\mathrm{~m}, 1 \mathrm{H}), 5.17-$ $5.31(\mathrm{~m}, 1 \mathrm{H}), 3.76(\mathrm{~s}, 3 \mathrm{H}), 3.63(\mathrm{~s}, 3 \mathrm{H}), 3.22$ (d, $J=2.1 \mathrm{~Hz}, 6 \mathrm{H}), 2.39-2.52$ (m, $1 \mathrm{H}), 2.28-2.39(\mathrm{~m}, 1 \mathrm{H}), 2.04-2.28(\mathrm{~m}, 3 \mathrm{H}), 1.86-2.02(\mathrm{~m}, 3 \mathrm{H}), 0.93$ (t, $J=7.5 \mathrm{~Hz}, 3 \mathrm{H}) \mathrm{ppm}$.

${ }^{13} \mathrm{C}$ NMR (CHLOROFORM- $\left.d, 125 \mathrm{MHz}\right): \delta=175.4,169.2,128.5,126.9,101.6,52.5,51.6,50.0$, $40.5,36.4,34.7,17.8 \mathrm{ppm}$. 


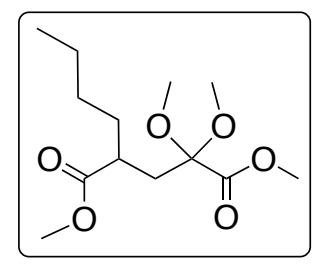

${ }^{1}$ H NMR (CHLOROFORM-d, 300MHz): $\delta=3.78(\mathrm{~s}, 3 \mathrm{H}), 3.65(\mathrm{~s}, 3 \mathrm{H}), 3.23$ (s, 3H), $3.22(\mathrm{~s}, 3 \mathrm{H}), 2.33-2.41(\mathrm{~m}, 2 \mathrm{H}), 1.85$ - $1.94(\mathrm{~m}, 1 \mathrm{H}), 1.51-1.61$ (m, 1H), $1.38-1.47(\mathrm{~m}, 1 \mathrm{H}), 1.16-1.32(\mathrm{~m}, 4 \mathrm{H}), 0.86(\mathrm{t}, J=7.0 \mathrm{~Hz}, 3 \mathrm{H})$ ppm.

${ }^{13}$ C NMR (CHLOROFORM-d, $\left.125 \mathrm{MHz}\right): \delta=176.0,169.2,101.6,52.5,51.6,50.0,40.3,35.8$, $33.3,29.1,22.4,13.8 \mathrm{ppm}$.

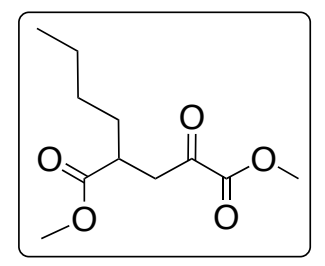

${ }^{1}$ H NMR (CHLOROFORM-d, 500MHz): $\delta=3.88(\mathrm{~s}, 3 \mathrm{H}), 3.69(\mathrm{~s}, 3 \mathrm{H}), 3.24$ - 3.35 (m, 1H), 2.87 - $3.01(\mathrm{~m}, 2 \mathrm{H}), 1.67$ (dd, J=14.5, 6.9 Hz, 1H), 1.49 $1.60(\mathrm{~m}, 1 \mathrm{H}), 1.19$ - $1.42(\mathrm{~m}, 4 \mathrm{H}), 0.89$ (t, $J=7.0 \mathrm{~Hz}, 3 \mathrm{H}) \mathrm{ppm}$.

${ }^{13} \mathrm{C}$ NMR (CHLOROFORM-d, $\left.125 \mathrm{MHz}\right): \delta=192.4,175.4,161.0,53.1$, 52.0, 40.7, 39.9, 31.4, 29.0, 22.4, 13.8 ppm.

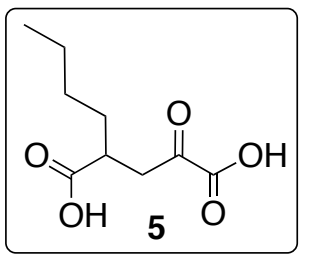

${ }^{1} H$ NMR (DEUTERIUM OXIDE, $\left.600 \mathrm{MHz}\right): \delta=2.71-2.91(\mathrm{~m}, 2 \mathrm{H}), 2.61$ $2.71(\mathrm{~m}, 1 \mathrm{H}), 1.49-1.60(\mathrm{~m}, 1 \mathrm{H}), 1.44$ (dq, $J=13.9,7.0 \mathrm{~Hz}, 1 \mathrm{H}), 1.16-1.31$ (m, 4H), $0.82(\mathrm{t}, J=7.0 \mathrm{~Hz}, 3 \mathrm{H}) \mathrm{ppm}$.

${ }^{13}$ C NMR (DEUTERIUM OXIDE, $\left.150 \mathrm{MHz}\right): \delta=183.3,170.6,162.8,42.3$, 41.5, 31.4, 28.7, 21.9, 13.2 ppm.

HRMS: Calculated for $\mathrm{C}_{9} \mathrm{H}_{13} \mathrm{O}_{5}[\mathrm{M}-\mathrm{H}]^{-}, 201.0758$; obtained 201.0755

\section{NMR data for 2KG 6 series:}

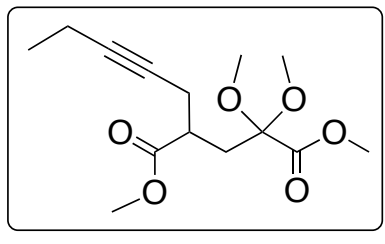

${ }^{1} H$ NMR (CHLOROFORM-d, $\left.500 \mathrm{MHz}\right): \delta=3.78(\mathrm{~s}, 3 \mathrm{H}), 3.67(\mathrm{~s}, 3 \mathrm{H})$, $3.27(\mathrm{~s}, 3 \mathrm{H}), 3.24(\mathrm{~s}, 3 \mathrm{H}), 2.54-2.64(\mathrm{~m}, 1 \mathrm{H}), 2.28-2.47(\mathrm{~m}, 3 \mathrm{H}), 2.07$ - $2.21(\mathrm{~m}, 3 \mathrm{H}), 1.03-1.12(\mathrm{~m}, 3 \mathrm{H}) \mathrm{ppm}$.

${ }^{13}$ C NMR (CHLOROFORM-d, $\left.125 \mathrm{MHz}\right): \delta=174.5,169.1,101.4,84.1$, $75.5,52.5,51.9,50.2,49.8,40.1,34.5,22.8,14.1,12.3$ ppm.

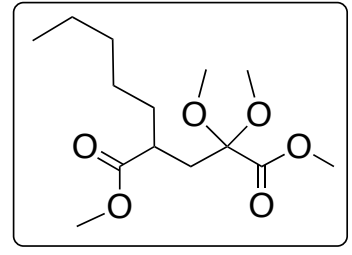

${ }^{1} H$ NMR (CHLOROFORM-d, $\left.500 \mathrm{MHz}\right): \delta=3.79$ (s, 3H), $3.66(\mathrm{~s}, 3 \mathrm{H})$, $3.24(\mathrm{~s}, 3 \mathrm{H}), 3.23(\mathrm{~s}, 3 \mathrm{H}), 2.36-2.44(\mathrm{~m}, 2 \mathrm{H}), 1.90(\mathrm{~d}, J=11.4 \mathrm{~Hz}, 1 \mathrm{H})$, $1.56(\mathrm{dd}, J=7.7,5.4 \mathrm{~Hz}, 1 \mathrm{H}), 1.39$ - 1.47 (m, 1H), 1.19 - 1.31 (m, 6H), 
$0.84-0.89(\mathrm{~m}, 3 \mathrm{H}) \mathrm{ppm}$.

${ }^{13} \mathrm{C} \mathrm{NMR}$ (CHLOROFORM-d, $125 \mathrm{MHz}$ ): $\delta=176.0,169.2,101.6,52.5,51.6,50.0,40.3,35.8$, $33.6,31.5,26.6,22.4,13.9 \mathrm{ppm}$.

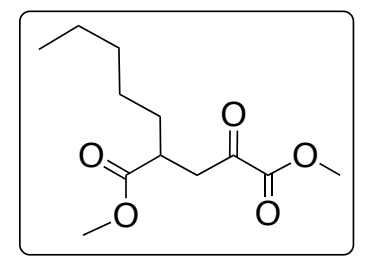

${ }^{1} H$ NMR (CHLOROFORM-d, 50OMHz): $\delta=3.88(\mathrm{~s}, 3 \mathrm{H}), 3.69(\mathrm{~s}, 3 \mathrm{H})$, $3.25-3.35(\mathrm{~m}, 1 \mathrm{H}), 2.87-3.02(\mathrm{~m}, 2 \mathrm{H}), 1.67(\mathrm{dd}, J=13.8,6.9 \mathrm{~Hz}, 1 \mathrm{H})$, 1.55 (dt, $J=13.8,6.7 \mathrm{~Hz}, 1 \mathrm{H}), 1.28$ (br. s., $7 \mathrm{H}), 0.88$ (t, $J=6.2 \mathrm{~Hz}, 3 \mathrm{H})$ ppm.

${ }^{13}$ C NMR (CHLOROFORM-d, 125MHz): $\delta=192.4,175.3,161.0,53.0,52.0,40.7,39.9,31.7$, $31.6,31.5,31.5,26.5,26.5,22.4,13.9 \mathrm{ppm}$.

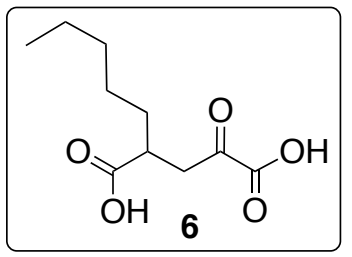

${ }^{1} H$ NMR (DEUTERIUM OXIDE, 600MHz): $\delta=2.87$ (br. s., 1H), $2.75-$ $2.81(\mathrm{~m}, 1 \mathrm{H}), 2.62-2.69(\mathrm{~m}, 1 \mathrm{H}), 1.50(\mathrm{dt}, J=13.7,7.1 \mathrm{~Hz}, 1 \mathrm{H}), 1.42(\mathrm{dq}$, $J=14.0,6.9 \mathrm{~Hz}, 1 \mathrm{H}), 1.18-1.31(\mathrm{~m}, 7 \mathrm{H}), 0.78-0.85(\mathrm{~m}, 3 \mathrm{H}) \mathrm{ppm}$.

${ }^{13} \mathrm{C}$ NMR (DEUTERIUM OXIDE, 150MHz): $\delta=183.5,170.5,162.8$, 42.6, 41.7, 31.8, 30.9, 26.2, 21.8, $13.3 \mathrm{ppm}$.

HRMS: Calculated for $\mathrm{C}_{10} \mathrm{H}_{15} \mathrm{O}_{5}[\mathrm{M}-\mathrm{H}]^{-}, 215.0914$; obtained 215.0913

\section{NMR data for 2KG 7 series:}

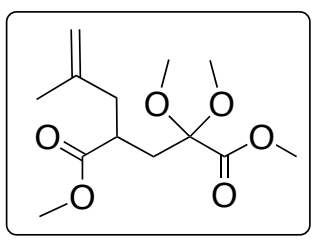

${ }^{1} H$ NMR (CHLOROFORM-d, 50OMHz): $\delta=4.79(\mathrm{~s}, 1 \mathrm{H}), 4.71(\mathrm{~s}, 1 \mathrm{H}), 3.79$ (s, $3 \mathrm{H}), 3.65$ (s, 3H), 3.24 (d, J=4.1 Hz, 6H), 2.60 - 2.67 (m, 1H), 2.27 $2.39(\mathrm{~m}, 2 \mathrm{H}), 2.11(\mathrm{dd}, J=13.7,7.9 \mathrm{~Hz}, 1 \mathrm{H}), 1.95(\mathrm{dd}, J=14.6,2.7 \mathrm{~Hz}, 1 \mathrm{H})$, $1.70(\mathrm{~s}, 3 \mathrm{H}) \mathrm{ppm}$.

${ }^{13}$ C NMR (CHLOROFORM-d, 125MHz): $\delta=175.5,169.1,141.9,113.4,101.5,52.4,51.6,50.0$, $50.0,41.8,38.7,35.0,21.7 \mathrm{ppm}$.

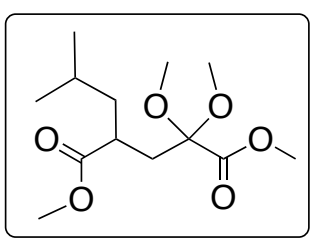

${ }^{1} H$ NMR (CHLOROFORM-d, 500MHz): $\delta=3.79(\mathrm{~s}, 3 \mathrm{H}), 3.65(\mathrm{~s}, 3 \mathrm{H}), 3.24$ $(\mathrm{s}, 3 \mathrm{H}), 3.22(\mathrm{~s}, 3 \mathrm{H}), 2.43-2.52(\mathrm{~m}, 1 \mathrm{H}), 2.34-2.41(\mathrm{~m}, 1 \mathrm{H}), 1.88(\mathrm{dd}$, $J=14.5,2.7 \mathrm{~Hz}, 1 \mathrm{H}), 1.68(\mathrm{~d}, J=14.0 \mathrm{~Hz}, 1 \mathrm{H}), 1.46-1.55$ (m, 2H), 1.18 $1.26(\mathrm{~m}, 1 \mathrm{H}), 0.89$ (d, $J=5.5 \mathrm{~Hz}, 3 \mathrm{H}), 0.83-0.87$ (m, 3H) ppm. 
${ }^{13}$ C NMR (CHLOROFORM- $\left.d, 125 \mathrm{MHz}\right): \delta=176.2,169.2,101.6,52.4,51.5,50.0,50.0,42.9$, $38.5,36.2,25.8,22.7,22.0 \mathrm{ppm}$.

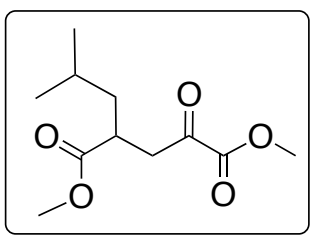

${ }^{1} H$ NMR (CHLOROFORM-d, 600MHz): $\delta=3.86-3.90(\mathrm{~m}, 3 \mathrm{H}), 3.69(\mathrm{~s}, 3$ H), 3.26 (dd, $J=18.8,9.4 \mathrm{~Hz}, 1 \mathrm{H}), 2.96-3.03$ (m, 1H), 2.93 (dd, $J=18.6,4.3$ $\mathrm{Hz}, 1 \mathrm{H}), 1.55$ - 1.65 (m, 2H), $1.31-1.39$ (m, 1H), 0.94 (d, J=6.0 Hz, 3H), $0.90(\mathrm{~d}, J=6.0 \mathrm{~Hz}, 3 \mathrm{H}) \mathrm{ppm}$.

${ }^{13}$ C NMR (CHLOROFORM-d, 150MHz): $\delta=192.3,175.4,161.0,53.0,51.9,41.1,40.9,38.1$, 25.8, 22.3, $22.3 \mathrm{ppm}$.

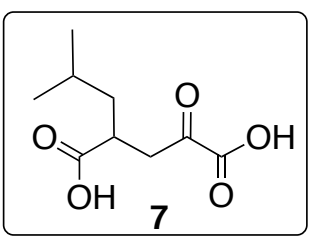

${ }^{1} H$ NMR (DEUTERIUM OXIDE, 500MHz): $\delta=2.93(\mathrm{dd}, J=18.0,8.4 \mathrm{~Hz}, 1$ H), 2.80 (dd, $J=18.0,5.8 \mathrm{~Hz}, 1 \mathrm{H}), 2.68$ (tt, $J=8.5,6.1 \mathrm{~Hz}, 1 \mathrm{H}), 1.45-1.55$ (m, 1H), 1.41 (ddd, $J=13.5,8.6,6.2 \mathrm{~Hz}, 1 \mathrm{H}), 1.20$ (ddd, $J=13.6,7.6,6.4 \mathrm{~Hz}$, $1 \mathrm{H}), 0.86(\mathrm{~d}, J=6.4 \mathrm{~Hz}, 3 \mathrm{H}), 0.82(\mathrm{~d}, J=6.6 \mathrm{~Hz}, 3 \mathrm{H}) \mathrm{ppm}$.

${ }^{13}$ C NMR (DEUTERIUM OXIDE, 125MHz): $\delta=205.5,184.4,170.3,42.8,41.8,41.8,25.7,22.2$, $21.8 \mathrm{ppm}$.

HRMS: Calculated for $\mathrm{C}_{9} \mathrm{H}_{13} \mathrm{O}_{5}[\mathrm{M}-\mathrm{H}]^{-}, 201.0758$; obtained 201.0757

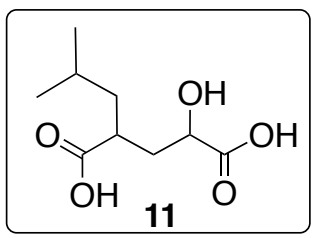

IH NMR (DEUTERIUM OXIDE, 400MHz): $\delta=3.82-4.00(\mathrm{~m}, 1 \mathrm{H}), 2.34-$ $2.58(\mathrm{~m}, 1 \mathrm{H}), 1.59-1.79(\mathrm{~m}, 2 \mathrm{H}), 1.36-1.59(\mathrm{~m}, 3 \mathrm{H}), 1.10-1.32(\mathrm{~m}, 1 \mathrm{H})$, $0.79-0.91(\mathrm{~m}, 6 \mathrm{H}) \mathrm{ppm}$.

${ }^{13}$ C NMR (DEUTERIUM OXIDE, 100MHz): $\delta=185.9,185.5,182.0,181.5$, 71.3, 71.0, 43.9, 40.8, 38.6, 26.0, 25.9, 23.3, 22.9, 22.6, 21.5, 21.2 ppm.

HRMS: Calculated for $\mathrm{C}_{9} \mathrm{H}_{15} \mathrm{O}_{5}[\mathrm{M}-\mathrm{H}]^{-}, 203.0914$; obtained 203.0920

\section{NMR data for 2KG 8 series:}

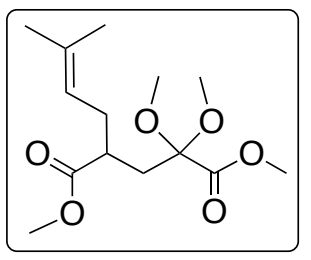

${ }^{1} H$ NMR (CHLOROFORM-d, 500MHz): $\delta=5.02(\mathrm{t}, J=6.8 \mathrm{~Hz}, 1 \mathrm{H}), 3.76-$ $3.80(\mathrm{~m}, 3 \mathrm{H}), 3.62-3.66(\mathrm{~m}, 3 \mathrm{H}), 3.19-3.27(\mathrm{~m}, 6 \mathrm{H}), 2.33$ - $2.49(\mathrm{~m}, 2 \mathrm{H})$, $2.25(\mathrm{~d}, J=7.0 \mathrm{~Hz}, 1 \mathrm{H}), 2.17(\mathrm{~d}, J=7.0 \mathrm{~Hz}, 1 \mathrm{H}), 1.93$ (dd, $J=14.4,2.2 \mathrm{~Hz}, 1$ 
H), 1.69 (s, 3H), 1.59 (s, 3H) ppm.

${ }^{13}$ C NMR (CHLOROFORM-d, 125MHz): $\delta=175.6,169.2,134.7,120.3,101.6,52.5,51.6,50.1$, $49.8,40.7,34.8,31.8,25.8,17.8 \mathrm{ppm}$.

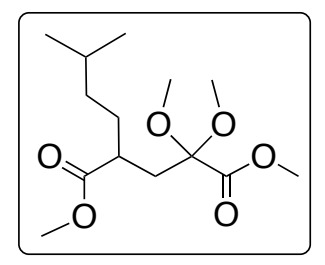

${ }^{l} H$ NMR (CHLOROFORM-d, 500MHz): $\delta=3.79(\mathrm{~s}, 3 \mathrm{H}), 3.66(\mathrm{~s}, 3 \mathrm{H}), 3.25$ (s, 3H), $3.23(\mathrm{~s}, 3 \mathrm{H}), 2.35-2.43(\mathrm{~m}, 2 \mathrm{H}), 1.85-1.95(\mathrm{~m}, 1 \mathrm{H}), 1.40-1.60$ (m, 3H), $1.03-1.20(\mathrm{~m}, 2 \mathrm{H}), 0.86(\mathrm{~d}, J=1.7 \mathrm{~Hz}, 3 \mathrm{H}), 0.84$ (d, $J=1.7 \mathrm{~Hz}, 3 \mathrm{H})$ ppm.

${ }^{13}$ C NMR (CHLOROFORM-d, 125MHz): $\delta=176.0,169.2,101.6,52.4,51.5,50.0,50.0,40.5$, $36.0,35.8,31.4,27.8,22.5,22.3 \mathrm{ppm}$.

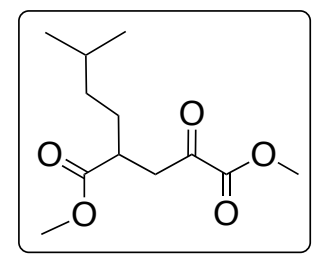

${ }^{1} H$ NMR (CHLOROFORM-d, 600MHz): $\delta=3.87(\mathrm{~s}, 3 \mathrm{H}), 3.68(\mathrm{~s}, 3 \mathrm{H}), 3.30$ (dd, $J=19.4,10.4 \mathrm{~Hz}, 1 \mathrm{H}), 2.91$ (dt, $J=15.1,4.3 \mathrm{~Hz}, 2 \mathrm{H}), 1.63-1.71$ (m, 1 H), 1.49 - 1.59 (m, 2H), 1.14 - $1.21(\mathrm{~m}, 2 \mathrm{H}), 0.87$ (d, $J=6.8 \mathrm{~Hz}, 6 \mathrm{H}) \mathrm{ppm}$. ${ }^{13}$ C NMR (CHLOROFORM-d, 150MHz): $\delta=192.3,175.1,161.0,53.0,51.9$, $40.6,40.0,35.9,29.6,27.9,22.4,22.3 \mathrm{ppm}$.

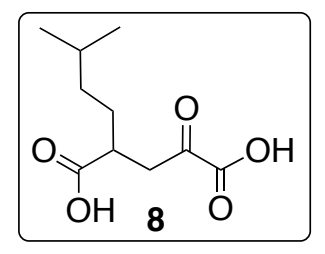

${ }^{1} H$ NMR (DEUTERIUM OXIDE, $\left.300 \mathrm{MHz}\right): \delta=2.93(\mathrm{dd}, J=18.0,8.2 \mathrm{~Hz}, 1$ H), $2.77(\mathrm{dd}, J=18.1,6.0 \mathrm{~Hz}, 1 \mathrm{H}), 2.46-2.59(\mathrm{~m}, 1 \mathrm{H}), 1.33-1.52(\mathrm{~m}, 3 \mathrm{H})$, 0.99 - 1.17 (m, 2H), 0.79 (d, $J=1.7 \mathrm{~Hz}, 3 \mathrm{H}), 0.77(\mathrm{~d}, J=1.7 \mathrm{~Hz}, 3 \mathrm{H}) \mathrm{ppm}$.

${ }^{13}$ C NMR (DEUTERIUM OXIDE, 100MHz): $\delta=205.3,184.0,170.2,43.4$, 43.3, 42.4, 35.9, 30.0, 27.3, 21.9, $21.7 \mathrm{ppm}$.

HRMS: Calculated for $\mathrm{C}_{10} \mathrm{H}_{15} \mathrm{O}_{5}[\mathrm{M}-\mathrm{H}]^{-}, 215.0914$; obtained 215.0919

\section{Synthesis and purification of peptides}

All the peptides were synthesized by the University of Pittsburgh Peptide Synthesis Facility (Table S4). Analytical-scale separation was performed using ZORBAX reversed-phase C18 $(5 \mu \mathrm{m}, 4.6 \times 250 \mathrm{~mm})$ column with UV detection at $280 \mathrm{~nm}$. The column was equilibrated with $0.1 \%$ aqueous trifluoroacetic acid solution prior to each injection. Analytical separation was performed with a linear gradient of acetonitrile to $10 \%$ in $15 \mathrm{~min}$ and then to $70 \%$ in $5 \mathrm{~min}$ in 
$0.1 \%$ aqueous trifluoroacetic acid with a flow rate of $1 \mathrm{~mL} / \mathrm{min}$. The crude peptides were purified using preparative reversed-phase HPLC (XBridge C18, $5 \mu \mathrm{m}, 10$ x $250 \mathrm{~mm}$ column) eluting with a flow rate of $5 \mathrm{~mL} / \mathrm{min}$ and a gradient of acetonitrile starting from $0 \%$ to $90 \%$ in 15 min and then to $100 \%$ in $18 \mathrm{~min}$ in aqueous trifluoroacetic acid $(0.01 \%)$. The purified peptides were first concentrated by SpeedVac concentrator followed by lyophilization. The dried peptides were resuspended in water containing $0.01 \%$ TFA and stored at $-80{ }^{\circ} \mathrm{C}$ before use. Concentrations of the peptides were determined based on the observation that $1 \mathrm{mg} / \mathrm{ml}$ peptide generates an absorbance value $\left(\mathrm{A}_{205}\right)$ of 30 at $205 \mathrm{~nm}$. The integrity of the purified peptide was confirmed by MALDI mass spectrometry.

\section{Synthesis and purification of oligonucleotides}

DNA and RNA oligonucleotides (Table S4) carrying $5 \mathrm{mC}$ and $\mathrm{m} 6 \mathrm{~A}$, respectively, were synthesized using standard DNA and RNA phosphoramidite monomers (Glen Research) under ultra-mild conditions using $1 \mathrm{H}$-tetrazole as activator reagent in an Expedite Nucleic Acid Synthesis System (PerSeptive Biosystems) with DMT-ON protocol. While 5mC phosphoramidite was purchased from Glen Research, m6A phosphoramidite (N6-methyl-50-O(4,40-dimethoxytrityl)-20-O-t-butyldimethylsilyl adenosine 30-O-(2-cyanoethyl-N,Ndiisopropyl) phosphoramidite) was synthesized according to a previously reported procedure. ${ }^{2}$ To ensure good coupling elongated (4 min $30 \mathrm{sec}$ ) coupling times were applied for the coupling of modified bases and for standard bases $(2 \mathrm{~min})$ normal coupling was applied. The crude oligonucleotide was cleaved from the beads and deprotected by incubating with ammonium hydroxide $(33 \% \mathrm{v} / \mathrm{v})$ at $25{ }^{\circ} \mathrm{C}$ for $24 \mathrm{hr}$. A preliminary purification and DMT deprotection were carried out using Poly Pak $^{\mathrm{II}}$ purification cartridge (Glen Research) according to the standard protocol provided by the manufacturer. Crude oligonucleotides were purified by HPLC using a C-18 column (Solvent A: 0.1 M TEAA, Solvent B: Acetonitrile; gradient for DNA: 0 min 5\% B, $10 \min 40 \% \mathrm{~B}, 15 \mathrm{~min} 100 \% \mathrm{~B}$ with a flow rate $4 \mathrm{~mL} / \mathrm{min}$, gradient for RNA: 0 min 3\% B, 20 $\min 15 \% \mathrm{~B}, 25 \mathrm{~min} 100 \% \mathrm{~B}$ with a flow rate $4 \mathrm{~mL} / \mathrm{min})$. The fractions were collected and concentrated by SpeedVac concentrator followed by lyophilization, and re-dissolved in RNAase free water. The quality and purity of synthesized DNA and RNA was monitored by high resolution MALDI-TOF-MS. 


\section{Mutagenesis, expression and purification of $2 \mathrm{KG}$ dependent oxygenases}

The N-terminal 6xHis-tagged human KDM4A-jmjC domain (catalytic domain of KDM4A) bacterial expression construct pNIC28-Bsa4 (Addgene ID: 38846) was obtained from Addgene. The wild type KDM4A plasmid was transformed into E. Coli BL21 (DE3) competent cells (Invitrogen) using pNIC28-Bsa4 kanamycin-resistant vector. A single colony was picked up and grown overnight at $37{ }^{\circ} \mathrm{C}$ in $10 \mathrm{~mL}$ of Luria-Bertani (LB) broth in the presence of $50 \mu \mathrm{g} / \mathrm{mL}$ kanamycin and $35 \mu \mathrm{g} / \mathrm{mL}$ chloramphenicol. The culture was diluted 100-fold and allowed to grow at $37{ }^{\circ} \mathrm{C}$ to an optical density $\left(\mathrm{OD}_{600}\right)$ of 0.8 , and protein expression was induced overnight at $17{ }^{\circ} \mathrm{C}$ with $0.6 \mathrm{mM}$ IPTG in an Innova $44 \AA$ Incubator shaker (New Brunswick Scientific). Proteins were purified as follows: harvested cells were resuspended in $15 \mathrm{~mL}$ lysis buffer (50 $\mathrm{mM}$ Tris- $\mathrm{HCl} \mathrm{pH}$ 8.0, $200 \mathrm{mM} \mathrm{NaCl}, 5 \mathrm{mM} \beta$-mercaptoethanol, 10\% glycerol, $25 \mathrm{mM}$ imidazole, Lysozyme, DNase, and Roche protease inhibitor cocktail). The cells were lysed by pulsed sonication (Qsonica-Q700), and centrifuged at $13000 \mathrm{rpm}$ for $40 \mathrm{~min}$ at $4{ }^{\circ} \mathrm{C}$. The soluble extracts were subject to Ni-NTA agarose resin (Thermo) according to manufacturer's instructions. After passing 20 volumes of washing buffer $(50 \mathrm{mM}$ Tris- $\mathrm{HCl} \mathrm{pH} 8.0,200 \mathrm{mM}$ $\mathrm{NaCl}, 5 \mathrm{mM} \beta$-mercaptoethanol, 10\% glycerol, and $25 \mathrm{mM}$ imidazole), proteins were eluted with a buffer containing $50 \mathrm{mM}$ Tris- $\mathrm{HCl}$ pH 8.0, $200 \mathrm{mM} \mathrm{NaCl,} 5 \mathrm{mM} \beta$-mercaptoethanol, 10\% glycerol, and $400 \mathrm{mM}$ imidazole. Proteins were further purified by size exclusion chromatography (Superdex-200) using AKTA pure FPLC system (GE healthcare) with buffer containing $50 \mathrm{mM}$ Tris- $\mathrm{HCl} \mathrm{pH} 8.0,200 \mathrm{mM} \mathrm{NaCl}$, and 10\% glycerol. Purified proteins were concentrated using Amicon Ultra-10k centrifugal filter device (Merck Millipore Ltd.). The protein concentration was determined using Bradford assay kit (BioRad Laboratories) with BSA as a standard. The concentrated proteins were stored at $-80^{\circ} \mathrm{C}$ before use. KDM4A variants were generated using the QuikChange Lightning site-directed mutagenesis kit (Agilent Technologies). The resulting mutant plasmids were confirmed by DNA sequencing. KDM4A variants were expressed and purified as stated for KDM4A-WT.

The N-terminal strep-tagged human KDM4B and KDM4D jmjC catalytic domain for bacterial

expression were kindly provided by Prof. Raymond Trievel, University of Michigan., ${ }^{3,4}$ The native constructs were transformed into E. coli Rosetta [DE3] competent cells. A single colony 
was picked up and grown overnight at $37{ }^{\circ} \mathrm{C}$ in $10 \mathrm{~mL}$ of Luria-Bertani (LB) broth in the presence of $100 \mu \mathrm{g} / \mathrm{mL}$ ampicillin and $35 \mu \mathrm{g} / \mathrm{mL}$ chloramphenicol. The culture was diluted 100fold and allowed to grow at $37{ }^{\circ} \mathrm{C}$ to an optical density $\left(\mathrm{OD}_{600}\right)$ of 0.8 , and protein expression was induced overnight at $18{ }^{\circ} \mathrm{C}$ with $1 \mathrm{mM}$ IPTG in an Innova 44® Incubator shaker (New Brunswick Scientific). Proteins were purified as follows: harvested cells were resuspended in 15 $\mathrm{mL}$ lysis buffer $(50 \mathrm{mM}$ Tris- $\mathrm{HCl} \mathrm{pH} 8.0,200 \mathrm{mM} \mathrm{NaCl}, 5 \mathrm{mM} \beta$-mercaptoethanol, 10\% glycerol, Lysozyme, DNase, and Roche protease inhibitor cocktail). The cells were lysed by pulsed sonication (Qsonica-Q700), and centrifuged at $13000 \mathrm{rpm}$ for $40 \mathrm{~min}$ at $4{ }^{\circ} \mathrm{C}$. The soluble extracts were subject to Strep-tactin resin (Qiagen, cat\# 30004) according to manufacturer's instructions. After passing 20 volumes of washing buffer $(50 \mathrm{mM}$ Tris- $\mathrm{HCl} \mathrm{pH} \mathrm{8.0,} 200 \mathrm{mM}$ $\mathrm{NaCl}, 5 \mathrm{mM} \beta$-mercaptoethanol, 10\% glycerol), proteins were eluted with a buffer containing 50 $\mathrm{mM}$ Tris- $\mathrm{HCl} \mathrm{pH} 8.0,200 \mathrm{mM} \mathrm{NaCl}, 5 \mathrm{mM} \beta$-mercaptoethanol, 10\% glycerol, and $5 \mathrm{mM} \mathrm{D}$ desthiobiotin. Proteins were further purified by size exclusion chromatography (Superdex-200) using AKTA pure FPLC system (GE healthcare) with buffer containing $50 \mathrm{mM}$ Tris-HCl pH 8.0, $200 \mathrm{mM} \mathrm{NaCl}$, and 10\% glycerol. Purified proteins were concentrated using Amicon Ultra-10k centrifugal filter device (Merck Millipore Ltd.). The protein concentration was determined using Bradford assay kit (BioRad Laboratories) with BSA as a standard. The concentrated proteins were stored at $-80^{\circ} \mathrm{C}$ before use. KDM4B-F186G and KDM4D-F189G were generated using the QuikChange Lightning site-directed mutagenesis kit (Agilent Technologies). The resulting mutant plasmids were confirmed by DNA sequencing. KDM4B/D variants were expressed and purified as stated for the native proteins.

The N-terminal 6xHis-tagged human KDM4C catalytic domain construct for bacterial expression was a kind gift from Prof. Danica Fujimori, UCSF. ${ }^{5}$ F187G mutant plasmid was generated using the QuikChange Lightning site-directed mutagenesis kit (Agilent Technologies). Plasmids were transformed into BL21 [DE3] star cells and grown at $37{ }^{\circ} \mathrm{C}$ to an optical density of 0.6. Protein expression was induced with $0.3 \mathrm{mM}$ IPTG overnight at $17{ }^{\circ} \mathrm{C}$. Following bacterial cell lysis, expressed protein was purified first by nickel affinity chromatography and secondly by size exclusion chromatography using a superdex 200 FPLC column. The proteins were concentrated via centrifugation. Protein concentration was determined using Bradford assay. 
The plasmid constructs for the catalytic domain of KDM6B was kindly provided by Prof. Christopher Schofield of the University of Oxford. ${ }^{6}$ Purified plasmid was transformed into Rosetta [DE3] competent cells. Propagation of plasmid-containing cells was performed in LuriaBertani (LB) broth at $37{ }^{\circ} \mathrm{C}$. Once the optical density reached $\sim 0.8$, protein expression was induced with $0.3 \mathrm{mM}$ IPTG shaking at $17{ }^{\circ} \mathrm{C}$ overnight. The cells were collected by centrifugation at $4000 \mathrm{rpm}$ for 30 minutes. Following bacterial cell lysis, expressed protein was purified first by nickel affinity chromatography and secondly by size exclusion chromatography using a superdex 200 FPLC column.

The plasmid constructs for the catalytic domain of the $\mathrm{m}^{6} \mathrm{~A}-\mathrm{RNA}$ demethylase Fat and Obesity associated protein (FTO), and 5-methyl-cytosine (5mC) DNA oxygenase Ten-elevenTranslocation-2 (TET2) were kind gifts from Profs. Chuan He of the University of Chicago and Yanhui Xu of the Fudan University. ${ }^{7,8}$ Wild type FTO and TET2 were expressed and purified as stated earlier for $\mathrm{N}-6 \mathrm{xH}$ is tag proteins.

\section{Expression and purification of Formaldehyde Dehydrogenase (FDH)}

The N-terminal 6xHis-tagged P. putida FDH bacterial expression construct in pET28 vector was obtained from the Bhagwat laboratory at the Wayne State University. ${ }^{9}$ The plasmid was transformed into E. coli Rosetta [DE3] competent cells. A single colony was picked up and grown overnight at $37{ }^{\circ} \mathrm{C}$ in $10 \mathrm{~mL}$ of Luria-Bertani (LB) broth in the presence of $50 \mu \mathrm{g} / \mathrm{mL}$ kanamycin and $35 \mu \mathrm{g} / \mathrm{mL}$ chloramphenicol. The culture was diluted 100 -fold and allowed to grow at $37{ }^{\circ} \mathrm{C}$ to an optical density $\left(\mathrm{OD}_{600}\right)$ of 0.8 , and protein expression was induced overnight at $18{ }^{\circ} \mathrm{C}$ with $1 \mathrm{mM}$ IPTG in an Innova $44 \mathbb{B}$ Incubator shaker (New Brunswick Scientific). Proteins were purified as follows: harvested cells were resuspended in $15 \mathrm{~mL}$ lysis buffer (50 $\mathrm{mM}$ Tris- $\mathrm{HCl} \mathrm{pH}$ 8.0, $200 \mathrm{mM} \mathrm{NaCl}, 5 \mathrm{mM} \beta$-mercaptoethanol, $10 \%$ glycerol, $25 \mathrm{mM}$ imidazole, Lysozyme, DNase, and Roche protease inhibitor cocktail). The cells were lysed by pulsed sonication (Qsonica-Q700), and centrifuged at $13000 \mathrm{rpm}$ for $40 \mathrm{~min}$ at $4{ }^{\circ} \mathrm{C}$. The soluble extracts were subject to Ni-NTA agarose resin (Thermo) according to manufacturer's instructions. After passing 20 volumes of washing buffer (50 mM Tris- $\mathrm{HCl} \mathrm{pH} 8.0,200 \mathrm{mM}$ $\mathrm{NaCl}, 5 \mathrm{mM} \beta$-mercaptoethanol, $10 \%$ glycerol, and $25 \mathrm{mM}$ imidazole), proteins were eluted with 
a buffer containing $50 \mathrm{mM}$ Tris- $\mathrm{HCl} \mathrm{pH} 8.0,200 \mathrm{mM} \mathrm{NaCl}, 5 \mathrm{mM} \beta$-mercaptoethanol, $10 \%$ glycerol, and $400 \mathrm{mM}$ imidazole. Proteins were further purified by size exclusion chromatography (Superdex-200) using AKTA pure FPLC system (GE healthcare) with buffer containing $50 \mathrm{mM}$ Tris- $\mathrm{HCl} \mathrm{pH} 8.0,200 \mathrm{mM} \mathrm{NaCl}$, and 10\% glycerol. Purified proteins were concentrated using Amicon Ultra-10k centrifugal filter device (Merck Millipore Ltd.). The protein concentration was determined using Bradford assay kit (BioRad Laboratories) with BSA as a standard. The concentrated proteins were stored at $-80^{\circ} \mathrm{C}$ before use.

\section{MALDI demethylase activity assay}

To monitor enzymatic activity, a demethylase activity assay was optimized and then observed through MALDI-TOF. ${ }^{4}$ Each histone demethylase assay sample included $10 \mu \mathrm{M}$ enzyme, $10 \mu \mathrm{M}$ peptide, $1 \mathrm{mM} 2 \mathrm{KG}$ /analogues, $50 \mathrm{mM}$ Tris $\mathrm{pH} 8,50 \mu \mathrm{M}\left(\mathrm{NH}_{4}\right)_{2} \mathrm{Fe}\left(\mathrm{SO}_{4}\right)_{2}$, and $2 \mathrm{mM}$ L-ascorbic acid with a total assay volume of $20 \mu \mathrm{l}$. Fe(II) supplement and L-ascorbic acid were prepared freshly. The $2 \mathrm{KG}$ was added last to the assay sample and briefly centrifuged. The samples were incubated at $37^{\circ} \mathrm{C}$ for three hours. To observe demethylase activity, $1 \mu \mathrm{L}$ of assay sample was applied to the MALDI plate followed by $1 \mu \mathrm{L}$ of CHCA matrix. The sample was analyzed using Voyager on the Reflector Positive mode. The negative control included all components of the assay except for the demethylating enzyme. For KDM4 inhibition studies, the demethylation protocol remains the same as for the activity, but the inhibitor $\mathbf{9 / 1 0} / \mathbf{1 1}$ was added (1-4 $\mathrm{mM})$ to the samples prior to the addition of $2 \mathrm{KG} \mathbf{1}$ or analogue $\mathbf{3} / 7(80 \mu \mathrm{M}) .{ }^{10}$

For DNA demethylation assessment, each assay sample included $10 \mu \mathrm{M}$ double-stranded DNA (5'-CAC-5 ${ }^{\mathrm{m}} \mathrm{C}-\mathrm{GGTG}-3$ '), $50 \mathrm{mM}$ HEPES pH 8, $100 \mathrm{mM} \mathrm{NaCl}, 100 \mu \mathrm{M}\left(\mathrm{NH}_{4}\right)_{2} \mathrm{Fe}\left(\mathrm{SO}_{4}\right)_{2}, 2 \mathrm{mM}$ L-Ascorbic Acid, 1 mM DTT (prepared freshly), 1 mM ATP, $10 \mu \mathrm{M}$ TET2 and $1 \mathrm{mM}$ 2KG 1 or analogues 3 and $7{ }^{8}$ The samples were incubated for $3 \mathrm{~h}$ at $37^{\circ} \mathrm{C}$. The samples were desalted using BT AG50W-X8 Resin (BioRad, Cat \# 143-5441). The DNA was analyzed through MALDI using 3-hydroxypicolinic acid (3-HPA) matrix. 
For mRNA demethylation by FTO, each assay sample included $5 \mu \mathrm{M}$ RNA with a methylated adenosine residue ( ${ }^{6} \mathrm{~A}$ ) (5'-CUG-G-m $\left.{ }^{6} \mathrm{~A}-\mathrm{CUG}-\mathrm{G}-3^{\prime}\right) 50 \mathrm{mM}$ HEPES $\mathrm{pH}$ 8.0, $150 \mathrm{mM} \mathrm{KCl}, 75$ $\mu \mathrm{M}\left(\mathrm{NH}_{4}\right)_{2} \mathrm{Fe}\left(\mathrm{SO}_{4}\right)_{2}, 2 \mathrm{mM}$ L-ascorbic acid, $10 \mu \mathrm{M}$ FTO and $300 \mu \mathrm{M} 2 \mathrm{KG} \mathbf{1}$ or analogues 3 and 7..$^{7}$ The samples incubated for $30 \mathrm{~min}$ at $37^{\circ} \mathrm{C}$ and were quenched by the addition of $0.3 \mu 1$ of $0.25 \mathrm{M}$ EDTA. The samples were desalted using AG50W-X8 resin. MALDI analysis was performed using THAP:Ammonium citrate (9:1) matrix. All assays were performed with a negative control, which did not contain enzyme and a positive control that contain wild-type enzyme and native $2 \mathrm{KG} \mathbf{1}$.

\section{Coupled fluorescence assay}

To determine the catalytic efficiency of the wild type and engineered KDM4A-2KG pairs, the demethylase activity was measure by fluorescence intensity of accumulated NADH by employing a coupled fluorescence intensity assay. ${ }^{9,4}$ The experiments were performed in 384well white Corning plates. The assay was composed of an enzyme cocktail (50 mM HEPES pH 8.0, $50 \mu \mathrm{M}\left(\mathrm{NH}_{4}\right)_{2} \mathrm{Fe}\left(\mathrm{SO}_{4}\right)_{2}, 1 \mathrm{mM}$ L-ascorbic acid, $1 \mathrm{mM} \mathrm{NAD+}, 200 \mathrm{nM} \mathrm{FDH}$, and $1 \mu \mathrm{M}$ KDM4A or KDM4A-F185G and a substrate cocktail $(0-175 \mu \mathrm{M} 2 \mathrm{KG} /$ analogue and $300 \mu \mathrm{M}$ $\mathrm{H} 3 \mathrm{~K}_{9} \mathrm{Me}_{3}$ peptide. The substrate cocktail was first applied to the microplate followed by the enzyme cocktail. The accumulation of NADH was measured by fluorescence intensity (excitation $=340 \mathrm{~nm}$, emission $=490 \mathrm{~nm}$ ) every 30 seconds over a period of 15 minutes on a TECAN Infinite M1000Pro. The data was analyzed using Graphpad Prism software and converted to $\mu \mathrm{M}$ of $\mathrm{H} 3 \mathrm{~K} 9 \mathrm{Me}_{3}$ demethylated using the NADH calibration curve. Only points within the linear range were used to calculate the slope for each $2 \mathrm{KG}$ concentration and the values were fitted to the Michaelis-Menten equation to get the $K_{\mathrm{M}}$ and $k_{\text {cat }}$ values. Experiments were performed in duplicates.

\section{NADH calibration curve}

To convert the relative fluorescence unit (RFU) values collected in the coupled fluorescence intensity assay, an NADH calibration curve was generated by measuring fluorescence intensity. ${ }^{2}$ NADH (ACROS, cat \#124530050) was added to assay buffer (50 mM HEPES pH 8, $50 \mu \mathrm{M}$ 
$\left(\mathrm{NH}_{4}\right)_{2} \mathrm{Fe}\left(\mathrm{SO}_{4}\right)_{2}, 1 \mathrm{mM}$ L-ascorbic acid, $1 \mathrm{mM} \mathrm{NAD+}, 200 \mathrm{nM} \mathrm{FDH}$, and $1 \mu \mathrm{M}$ KDM4A) in varying concentrations $(0-10 \mu \mathrm{M})$. The experiments were performed in 384-well white Corning plates. The fluorescence intensity was measured with excitation $=340 \mathrm{~nm}$ and emission $=490$ $\mathrm{nm}$ on a TECAN Infinite M1000Pro. Triplicate values were taken for each concentration.

\section{Expression and purification of histone $\mathrm{H3}$ and its mutants}

Gene sequence encoding wild type Xenopus laevis histone H3 was a kind gift from Prof. Minkui Luo at the Memorial Sloan-Kettering Cancer Center. The plasmid containing histone H3-C110A was transformed into BL21 codon plus (DE3) RIPL competent cells. A single colony was picked up and grown overnight at $37^{\circ} \mathrm{C}$ in $10 \mathrm{~mL}$ of LB broth with $100 \mu \mathrm{g} / \mathrm{mL}$ ampicillin and $35 \mu \mathrm{g} / \mathrm{mL}$ chloramphenicol. The inoculation culture was diluted 1:100 fold in fresh LB medium and cells were grown at $37^{\circ} \mathrm{C}$ until $\mathrm{OD}_{600}$ reached to $\sim 0.7$. Protein expression was induced by the addition of $0.3 \mathrm{mM}$ IPTG followed by growing for an additional $3 \mathrm{~h}$ at $37{ }^{\circ} \mathrm{C}$. Cells were harvested by centrifugation at $5000 \mathrm{rpm}$ for $30 \mathrm{~min}$, and then resuspension of the pellet in $5 \mathrm{~mL}$ of lysis buffer (10 mM Tris- $\mathrm{HCl} \mathrm{pH}$ 7.5, $2 \mathrm{M}$ guanidinium hydrochloride (GdnHCl), $5 \mathrm{mM} \beta$-mercaptoethanol, $10 \%$ glycerol, DNase, Lysozyme and Roche protease inhibitor cocktail). The cells were lysed by pulsed sonication and centrifuged at $20,000 \mathrm{~g}$ for $40 \mathrm{~min}$ at $4{ }^{\circ} \mathrm{C}$. Insoluble histone was recovered from inclusion bodies by dissolving in $6 \mathrm{M} \mathrm{GdnHCl}$ and $10 \mathrm{mM}$ Tris- $\mathrm{HCl} \mathrm{pH} 7.5$, and incubated for $10 \mathrm{~min}$ at room temperature followed by centrifugation at $20,000 \mathrm{~g}$ for $40 \mathrm{~min}$ at $4{ }^{\circ} \mathrm{C}$. The soluble histone supernatant was purified by size exclusion chromatography on a Superdex-200 using AKTA pure FPLC system. ${ }^{5}$ Fractions were concentrated using Amicon Ultra-4 centrifugal $3 \mathrm{~K}$ filter and further purified with preparative reverse-phase HPLC (XBridge C18, $5 \mu \mathrm{m}, 10 \mathrm{x}$ $250 \mathrm{~mm}$ column) eluting with a flow rate of $4 \mathrm{~mL} / \mathrm{min}$ starting from $10 \%$ acetonitrile to $70 \%$ in $15 \mathrm{~min}$ and then to $100 \%$ over $5 \mathrm{~min}$ in aqueous trifluoroacetic acid $(0.01 \%)$. The purified protein was concentrated by SpeedVac followed by lyophilization. The protein was stored at $80^{\circ} \mathrm{C}$ before use.

Histone $\mathrm{H} 3$ mutant $\mathrm{K} 9 \mathrm{C}\left(\mathrm{H}_{3} \mathrm{~K}_{\mathrm{C}} 9\right)$ was generated by the QuikChange Lightning site-directed mutagenesis kit (Agilent Technologies) following manufacturer's protocol. The resulting mutant 
plasmid was confirmed by DNA sequencing. $\mathrm{H}_{3} \mathrm{~K}_{\mathrm{C}} 9$ was expressed and purified as described above for the wild type Histone H3.

\section{Chemical trimethylation of $H 3 K_{C} 9$}

For the generation of trimethylated $\mathrm{H}_{3} \mathrm{~K}_{\mathrm{C}} 9 \mathrm{Me}_{3}, 1 \mathrm{mg}$ of lyophilized histone was dissolved in 98 $\mu 1$ of alkylation buffer (4 M Guanidine-Hydrochloride, $1 \mathrm{M}$ HEPES pH 7.8, $10 \mathrm{mM} \mathrm{D/L-}$ methionine). ${ }^{11,12}$ Once histone was fully dissolved, $2 \mu 1$ of 1 M DTT (prepared fresh) was added to the histone solution followed by $1 \mathrm{~h}$ incubation at $37^{\circ} \mathrm{C}$. The solution was then added to 10 mg of (2-bromoethyl) trimethyl ammonium bromide (Sigma, cat\# 117196) and protected from light. After incubating for $2.5 \mathrm{~h}$ at $50{ }^{\circ} \mathrm{C}$ (gently agitating every $30 \mathrm{~min}$ ), $1 \mu \mathrm{l}$ of $1 \mathrm{M}$ DTT was added to quench the reaction. The solution incubated at $50{ }^{\circ} \mathrm{C}$ for an additional $2.5 \mathrm{~h}$. The reaction was quenched by adding $5 \mu 1 \beta$-mercaptoethanol ( $\beta$-ME). A PD10 (GE, cat\# 17-0851$01)$ column was used to desalt the solution and the histones were eluted with $2 \mathrm{mM} \beta$-ME. SDSPAGE was performed to determine presence of the histone protein. The samples were lyophilized and then resuspended in $50 \mathrm{mM}$ Tris $\mathrm{pH}$ 8.0. Protein concentration was determined by Bradford assay and the molecular weight was verified by LC-MS. Protein was stored in -80 ${ }^{\circ} \mathrm{C}$ until used in demethylase activity assay.

\section{Demethylase activity assay on $\mathrm{H}_{3} \mathrm{~K}_{\mathrm{C}} 9 \mathrm{Me}_{3}$}

A demethylase activity assay was conducted to determine if KDM4A-F185G was active towards full-length human histone $\mathrm{H}_{3} \mathrm{~K}_{\mathrm{C}} 9 \mathrm{Me}_{3}$. The samples included $30 \mu \mathrm{M} \mathrm{H} 3 \mathrm{~K}_{\mathrm{C}} 9 \mathrm{Me}_{3}, 50 \mu \mathrm{M}$ enzyme, $2 \mathrm{mM} 2 \mathrm{KG} 1$ (or analogue 3/7), $100 \mu \mathrm{M}\left(\mathrm{NH}_{4}\right)_{2} \mathrm{Fe}\left(\mathrm{SO}_{4}\right)_{2}, 2 \mathrm{mM} \mathrm{L}$-ascorbic acid, $50 \mathrm{mM}$ Tris pH 8.0 (degassed), $1 \mathrm{mM}$ TCEP (freshly prepared) and $10 \%$ glycerol $(\mathrm{v} / \mathrm{v})$. The samples were incubated for $3 \mathrm{~h}$ at $37^{\circ} \mathrm{C}$ and were then purified through a C-18 Sep-pak column (Waters, cat\# WAT054955). The histones were concentrated by speed vacuum and analyzed for demethylation by LC-MS. The negative control did not include enzyme. 


\section{Demethylase activity assay on calf histones}

Lyophilyzed calf thymus histones were first dissolved in $50 \mathrm{mM}$ Tris $\mathrm{pH}$ 8.0. To determine if wild type KDM4A and its F185G mutant were active towards full length histones, $25 \mu \mathrm{g}$ of calf histone was incubated with $50 \mu \mathrm{M}$ KDM4A-WT or KDM4A-F185G and $2 \mathrm{mM} 2 \mathrm{KG} 1$ or analogue 3/7 in buffer containing $100 \mu \mathrm{M}\left(\mathrm{NH}_{4}\right)_{2} \mathrm{Fe}\left(\mathrm{SO}_{4}\right)_{2}, 2 \mathrm{mM}$ L-ascorbic acid and $50 \mathrm{mM}$ Tris $\mathrm{pH} 8.0$ for $2.5 \mathrm{~h}$ at $37^{\circ} \mathrm{C}$. After incubation, the samples were analyzed via western blotting.

\section{Mammalian cell culture and cell lysis}

Human embryonic kidney (HEK) 293 T cells were grown in Dulbecco modified Eagle medium (DMEM) (Gibco) supplemented with 10\% fetal calf serum in a humidified atmosphere containing $5 \% \mathrm{CO}_{2}$ in a $\mathrm{T} 75$ flask. At $\sim 80 \%$ confluence, cells were treated with $150 \mu \mathrm{M}$ of KDM4 inhibitor IOX1 (TOCRIS, cat\# 4464) ${ }^{13,14}$ dissolved in DMSO to generate hypermethylated histones. 24 hours post treatment, cells were harvested and lysed with $300 \mu \mathrm{L}$ of cold RIPA buffer (Sigma) supplemented with 1X Roche protease inhibitor cocktail and $5 \mathrm{mM}$ TCEP by sonicating for $15 \mathrm{~min}$ at amplitude of 100 with a repeating 1 min pulse cycle at $4{ }^{\circ} \mathrm{C}$. Cell lysates were centrifuged at $12,000 \mathrm{rpm}$ for $30 \mathrm{~min}$ at $4{ }^{\circ} \mathrm{C}$ to remove cell debris. The supernatant was then passed through the detergent removal spin column (Pierce \# 87778) and eluted with Tris buffer (50 mM Tris- $\mathrm{HCl}$ pH 8.0, 10\% glycerol, $2 \mathrm{mM}$ TCEP, $1 \mathrm{X}$ Roche protease inhibitor cocktail) following manufacturer's protocol. Protein concentration was determined by Bradford assay (Bio-Rad Laboratories). This stock solution was used for subsequent demethylase activity and inhibition assays as described below.

\section{Demethylase activity assay in HEK293T cell lysates}

For demethylase investigation, $100 \mu \mathrm{g}$ of HEK293T cell lysate was incubated with $50 \mu \mathrm{M}$ of KDM4A-WT or KDM4A-F185G in buffer containing $25 \mathrm{mM}$ Tris $\mathrm{pH} 8.0,100 \mu \mathrm{M}$ $\left(\mathrm{NH}_{4}\right)_{2} \mathrm{Fe}\left(\mathrm{SO}_{4}\right)_{2}, 2 \mathrm{mM}$ L-ascorbic acid, 10\% glycerol and 100-500 $\mu \mathrm{M} 2 \mathrm{KG}$ /analogues. After $2.5 \mathrm{~h}$ of incubation at $37^{\circ} \mathrm{C}$ the samples were analyzed for demethylation by western blotting. 
For inhibitory investigation, 25-50 $\mu \mathrm{M}$ of KDM4A-WT or KDM4A-F185G was incubated with 4-6 $\mathrm{mM}$ of 2HG $\mathbf{9}$ or analogues $\mathbf{1 0}$ or $\mathbf{1 1}$ for 20 mins at room temperature. The enzyme and inhibitor cocktail was then added to $100 \mu \mathrm{g}$ of HEK293T cell lysates and buffer containing 25 $\mathrm{mM}$ Tris $\mathrm{pH}$ 8.0, $100 \mu \mathrm{M}\left(\mathrm{NH}_{4}\right)_{2} \mathrm{Fe}\left(\mathrm{SO}_{4}\right)_{2}, 2 \mathrm{mM}$ L-ascorbic acid, $10 \%$ glycerol and 100-500 $\mu \mathrm{M} 2 \mathrm{KG} /$ analogues. The samples were incubated at $37^{\circ} \mathrm{C}$ for $2.5 \mathrm{~h}$ and subsequently analyzed for inhibition by western blotting.

\section{Western blotting}

Equal volumes of the assay sample (both for calf histone and cell lysate) were separated on SDSPAGE and transferred onto a $0.2 \mu \mathrm{m}$ supported nitrocellulose membrane (Bio-Rad Laboratories) at a constant voltage of 40 for $2.5 \mathrm{~h}$ at $4{ }^{\circ} \mathrm{C}$. Membranes were blocked with $20 \mathrm{~mL}$ of TBST buffer (50 mM Tris $\mathrm{HCl} \mathrm{pH} \mathrm{7.4,} 200 \mathrm{mM} \mathrm{NaCl}, 0.01 \%$ Tween-20) with 5\% nonfat dry milk for 1 hr. at room temperature with gentle shaking. The blocking buffer was then removed and membranes were washed with $20 \mathrm{~mL}$ of TBST buffer. Immunoblotting was performed with 1:500 diluted primary antibody (Histone-H3 mAb, cat\# 61475, Active Motif; Histone H3K9 $\mathrm{Me}_{3}$ mAb, cat\# 61013, Active Motif; Histone H3K9Me ${ }_{1}$, cat\# 39681, Active Motif) for $12 \mathrm{~h}$ at $4^{\circ} \mathrm{C}$. The antibody solutions were removed and membranes were washed three times with TBST buffer. The blots were then incubated with HRP-conjugated secondary antibody Goat anti-Mouse IgG (cat\# 15014, Active motif) with 5\% nonfat dry milk (1:10000 dilution) in TBST for $1.5 \mathrm{~h}$ at room temperature. After similar washing, protein bands were visualized by chemiluminescence using VISIGLO HRP Chemiluminescent substrates A and B (cat\# N252-120ML and N253120ML, aMReSCO) following manufacturer's protocol.

\section{LC-MS analysis}

Protein samples were loaded onto a PLRP-S column (Higgins Analytical, $5 \mu \mathrm{m}, 1000 \mathrm{~A}, 300 \mu \mathrm{m}$ i.d. $\times 100 \mathrm{~mm}$ ) of the LC system (Ultimate 3000, Dionex, Sunnyvale, CA) online coupled to an electrospray ionization (ESI) time-of-flight mass spectrometer (micrOTOF, BrukerDaltonics, Billerica, MA). Chromatographic separation was performed at a constant flow rate of $3.5 \mu \mathrm{L} /$ min using a binary solvent system (solvent A: water with $2.5 \%$ acetonitrile and $0.1 \%$ formic acid; 
solvent B: acetonitrile with $0.1 \%$ formic acid) and a linear gradient program (0-5 min, 5\% B; 510 min, 5-30\% B; 10-35 min, 30-70\% B; 35-44 min, 70\% B; 44-45 min, 70-5\% B; 45-60 min, 5\% B). Mass spectra were acquired in positive ion mode over the mass range $\mathrm{m} / \mathrm{z} 50$ to 3000 . ESI spectra were deconvoluted to obtain molecular ion masses with Data Analysis 3.3 (Bruker Daltonics, Billerica, MA) using the MaxEnt algorithm resulting in a mass accuracy of $0.01 \%$. 


\section{Supplementary figures and tables}

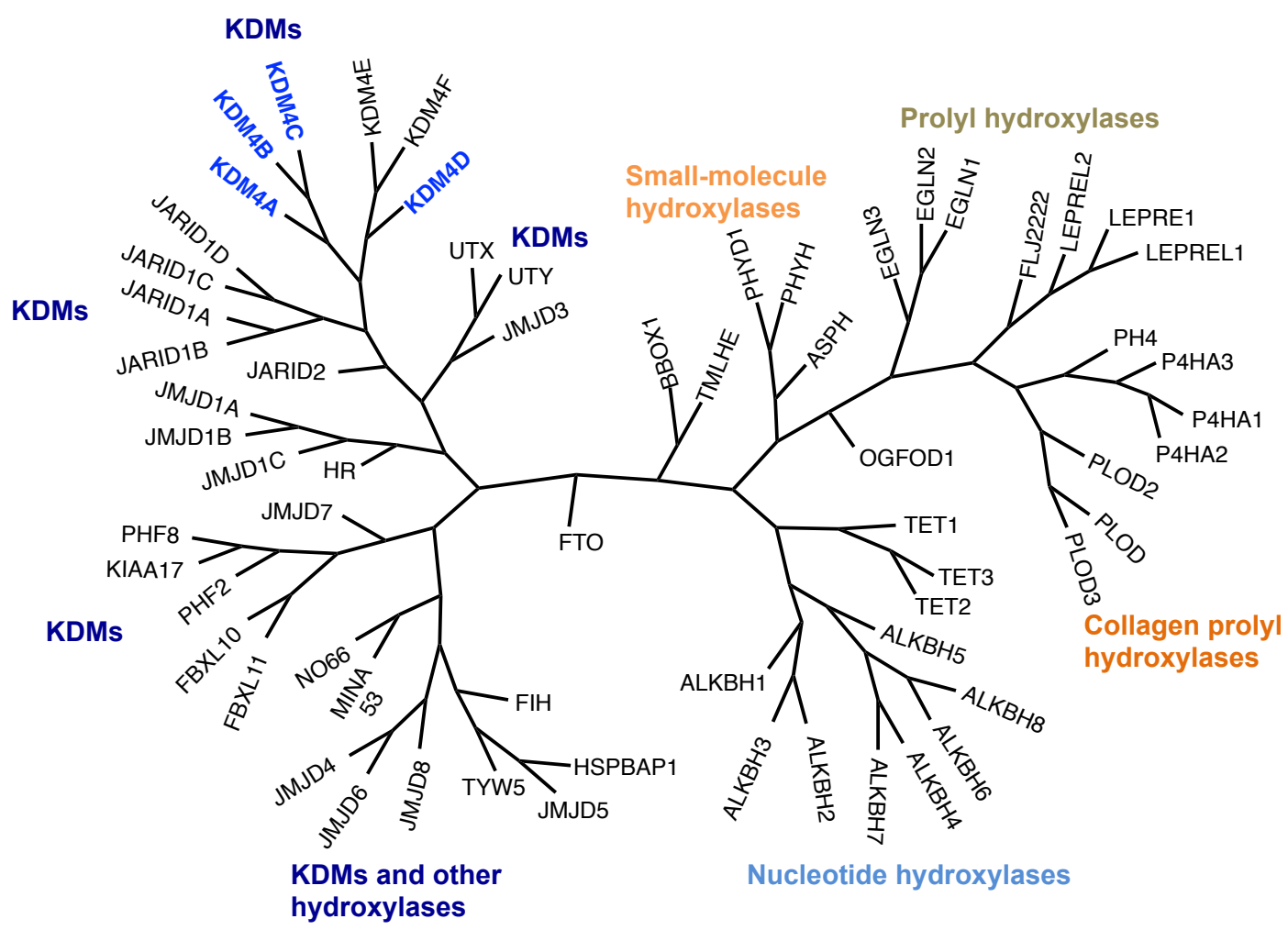

Supplementary Figure S1. Phylogenetic analysis of human KGOs. More than 30 of these KGOs are lysine demethylases (KDMs), many of which are not fully characterized. KDM4 members (shown in blue) are engineered in the current study. The figure is adapted from reference $15 .^{15}$
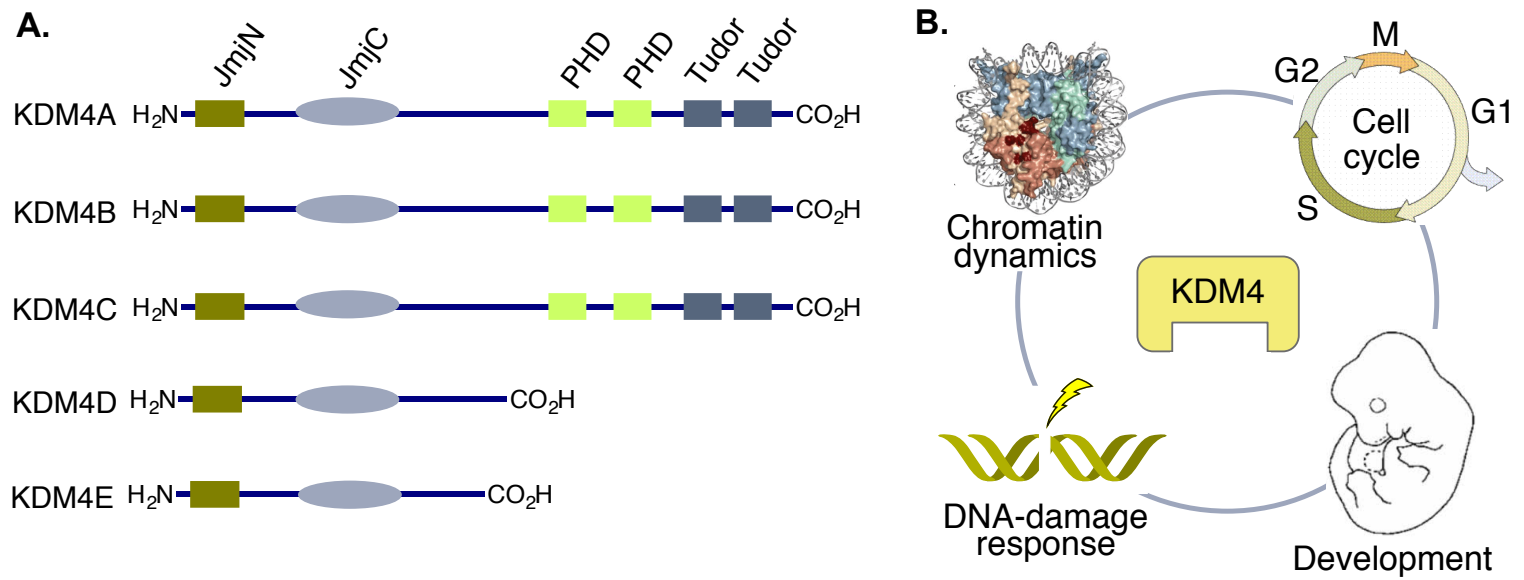

Supplementary Figure S2. Supplementary Figure S2: Human KDM4. A) Schematic showing KDM4 domain arrangements. JmjN and JmjC together form the catalytic domain. B) KDM4 members participate in diverse cellular and physiological processes. ${ }^{16}$ Biological implications are primarily due to KDM4-mediated transcriptional reprogramming. 

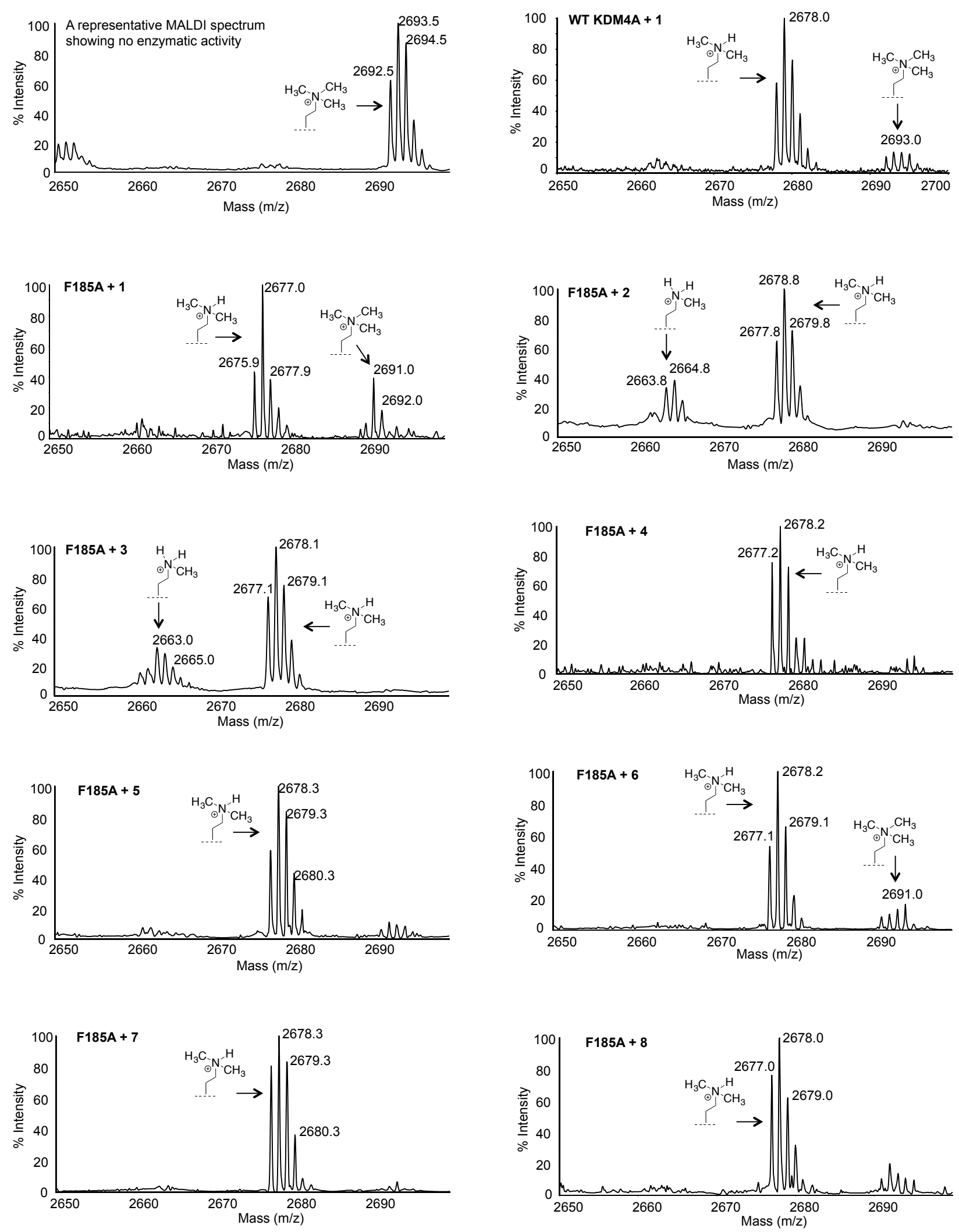

Supplementary Figure S3. MALDI spectra showing enzymatic activity of wild type KDM4A and its mutants towards $\mathrm{H} 3 \mathrm{~K}_{9} \mathrm{Me}_{3}$ peptide using $2 \mathrm{KG} \mathbf{1}$ and the analogues 2-8. 

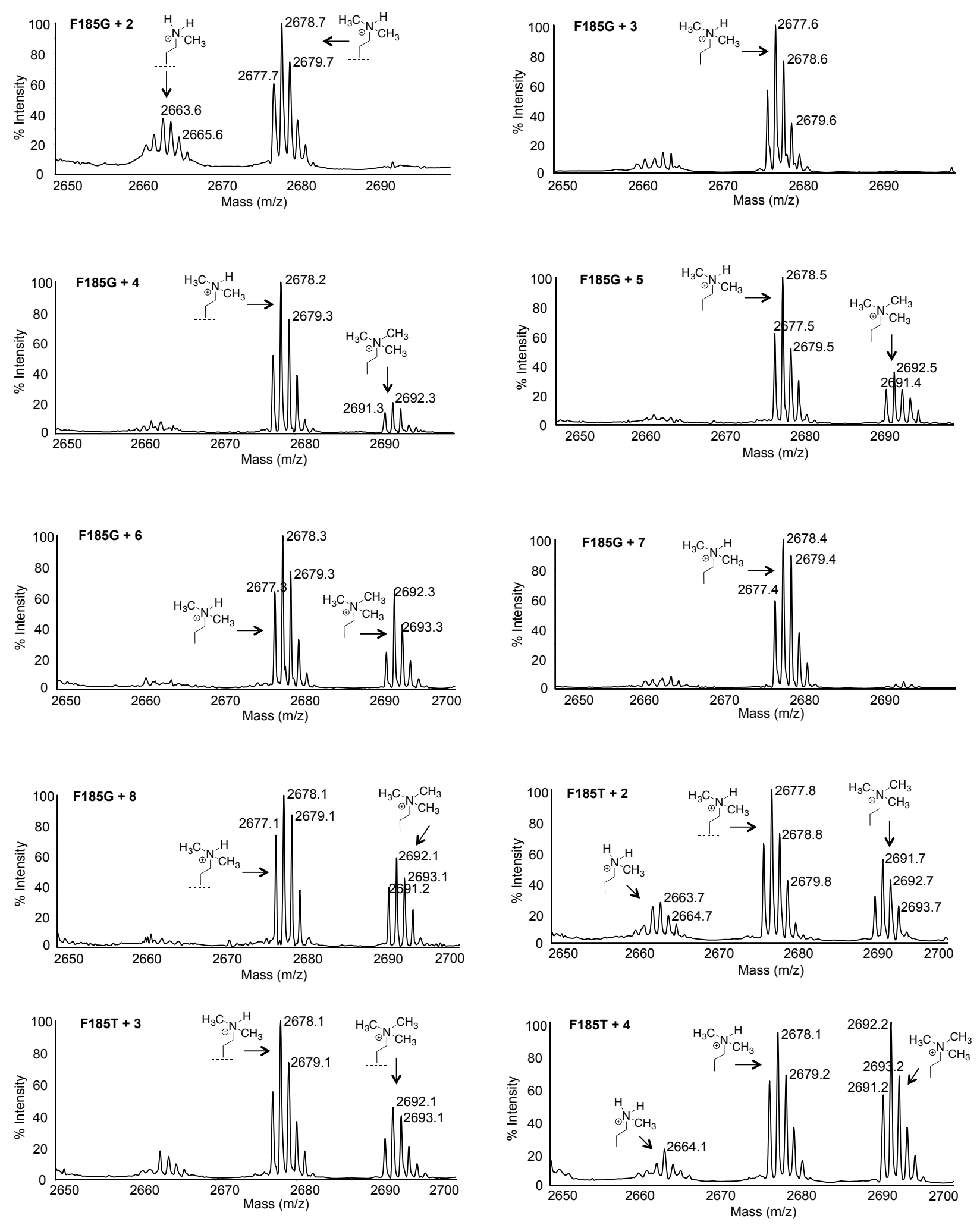

Supplementary Figure S3 continued. MALDI spectra showing enzymatic activity of wild type KDM4A and its mutants towards $\mathrm{H}_{3} \mathrm{~K}_{9} \mathrm{Me}_{3}$ peptide using $2 \mathrm{KG} \mathbf{1}$ and the analogues $\mathbf{2 - 8}$. 

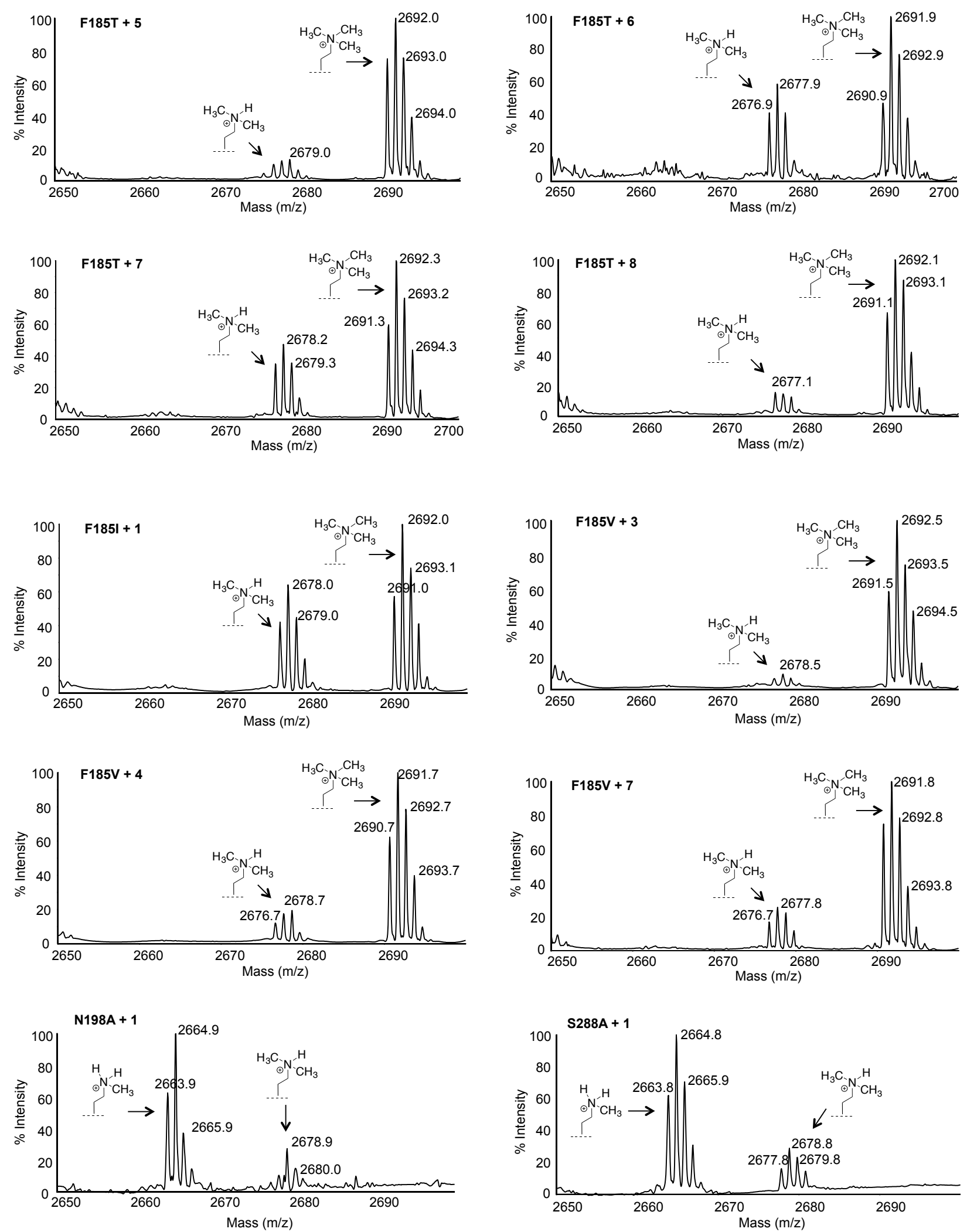

Supplementary Figure S3 continued. MALDI spectra showing enzymatic activity of wild type KDM4A and its mutants towards $\mathrm{H}_{3} \mathrm{~K}_{9} \mathrm{Me}_{3}$ peptide using $2 \mathrm{KG} \mathbf{1}$ and the analogues $\mathbf{2 - 8}$. 


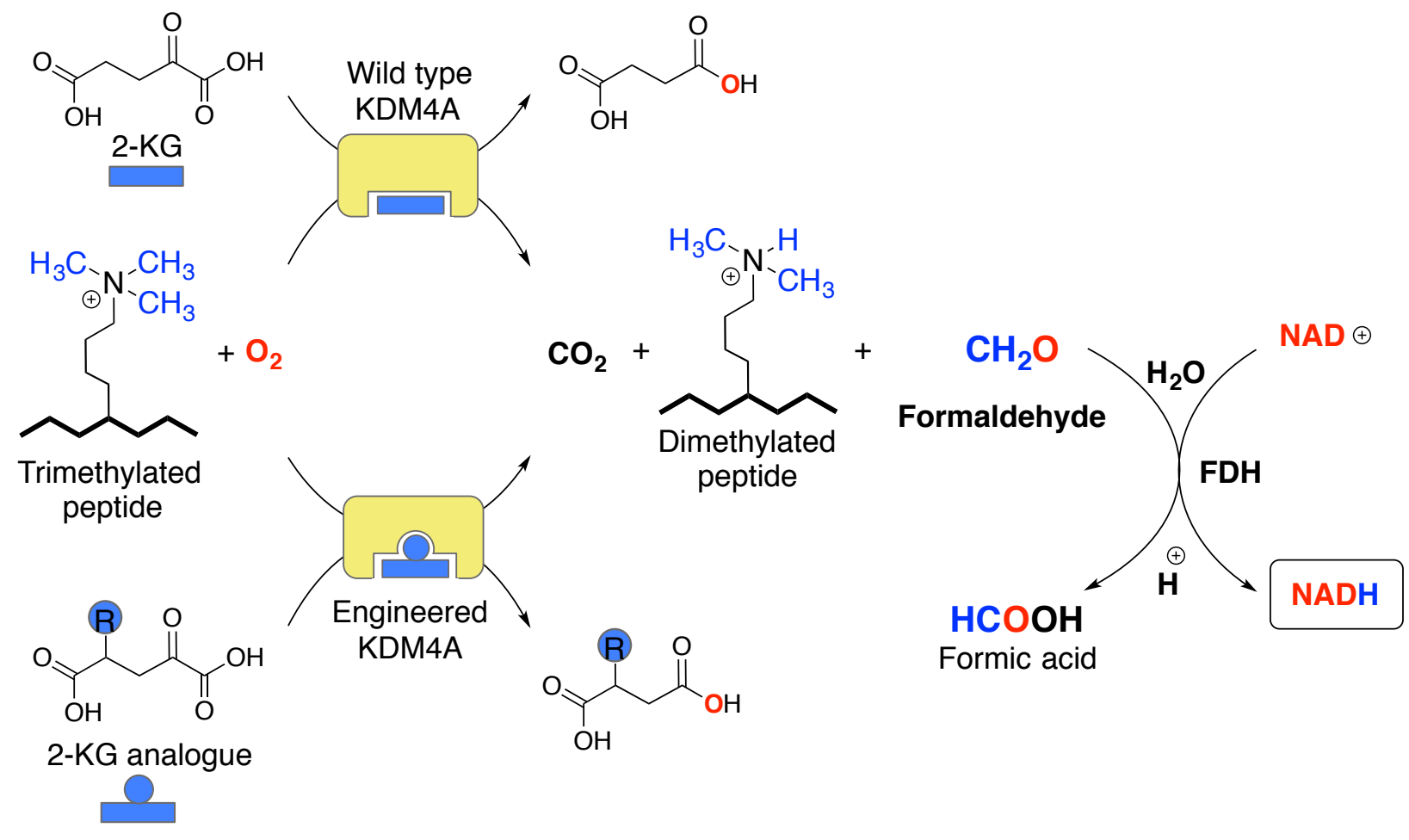

Supplementary Figure S4: Coupled fluorescence assay to measure kinetic parameters of KDM4A-1 and F185G-3/7 pairs. Formaldehyde produced in demethylation of methylated peptide by wild type and engineered systems can be oxidized by formaldehyde dehydrogenase (FDH) using $\mathrm{NAD}^{+}$as oxidant. The amount of NADH generated is measured using fluorescence intensity at $\lambda_{\max } 340 \mathrm{~nm}$. 

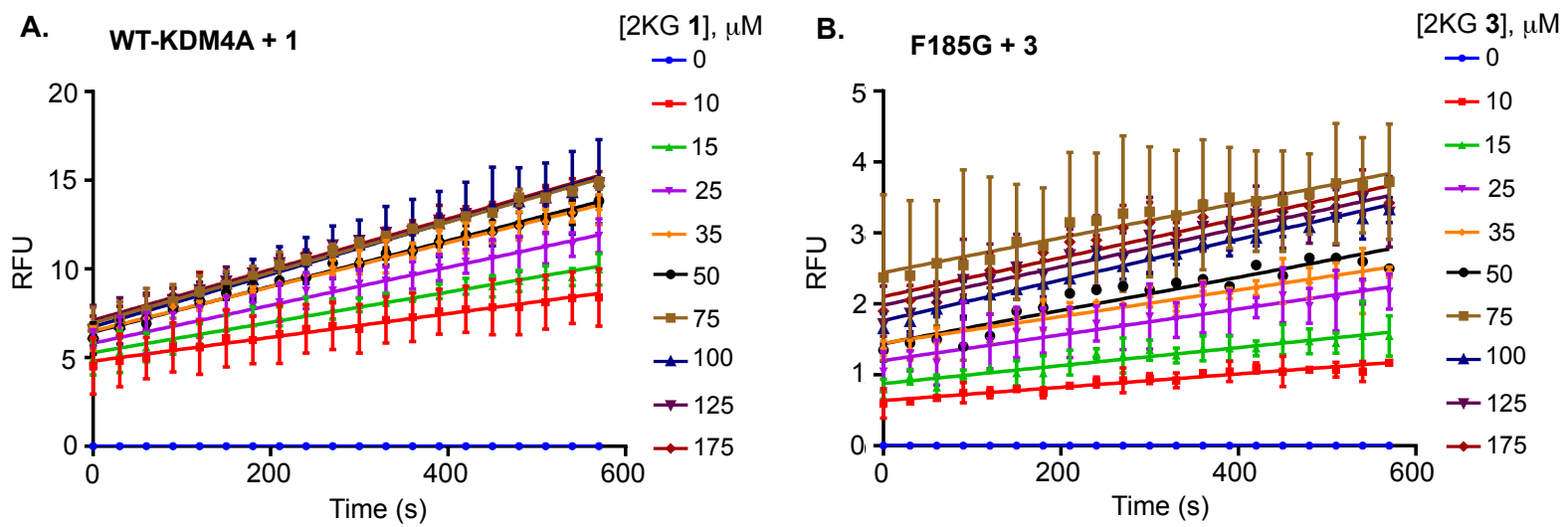

c.

D.
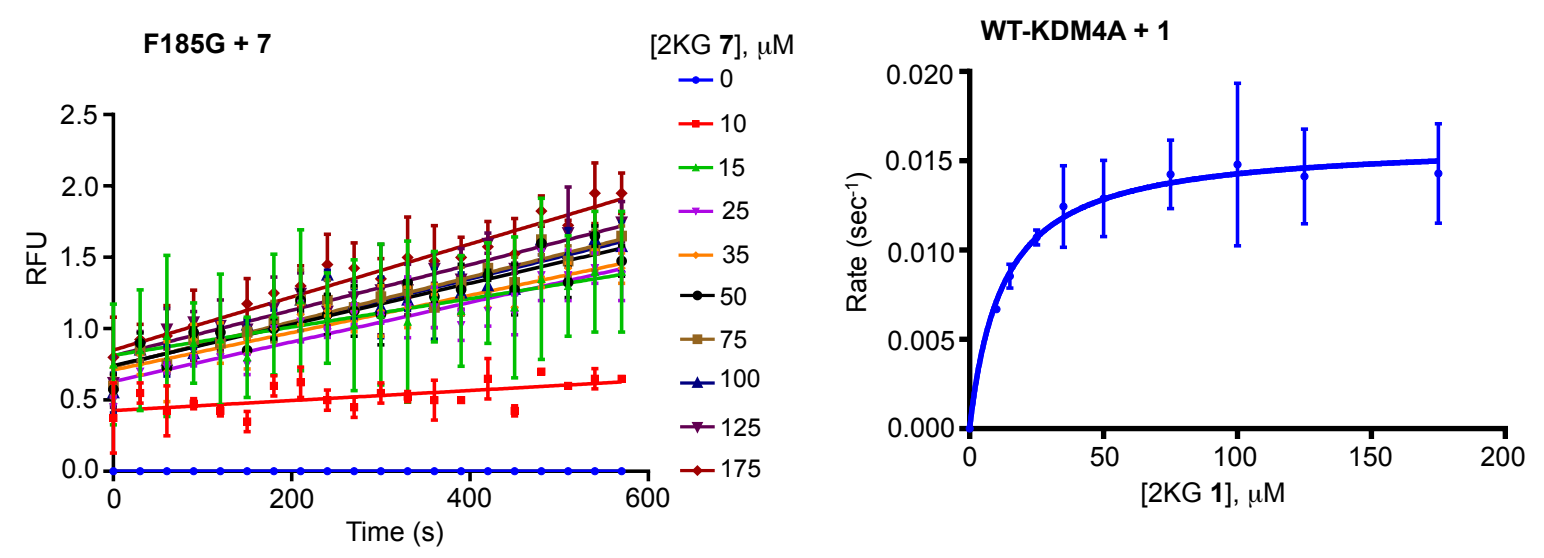

E.
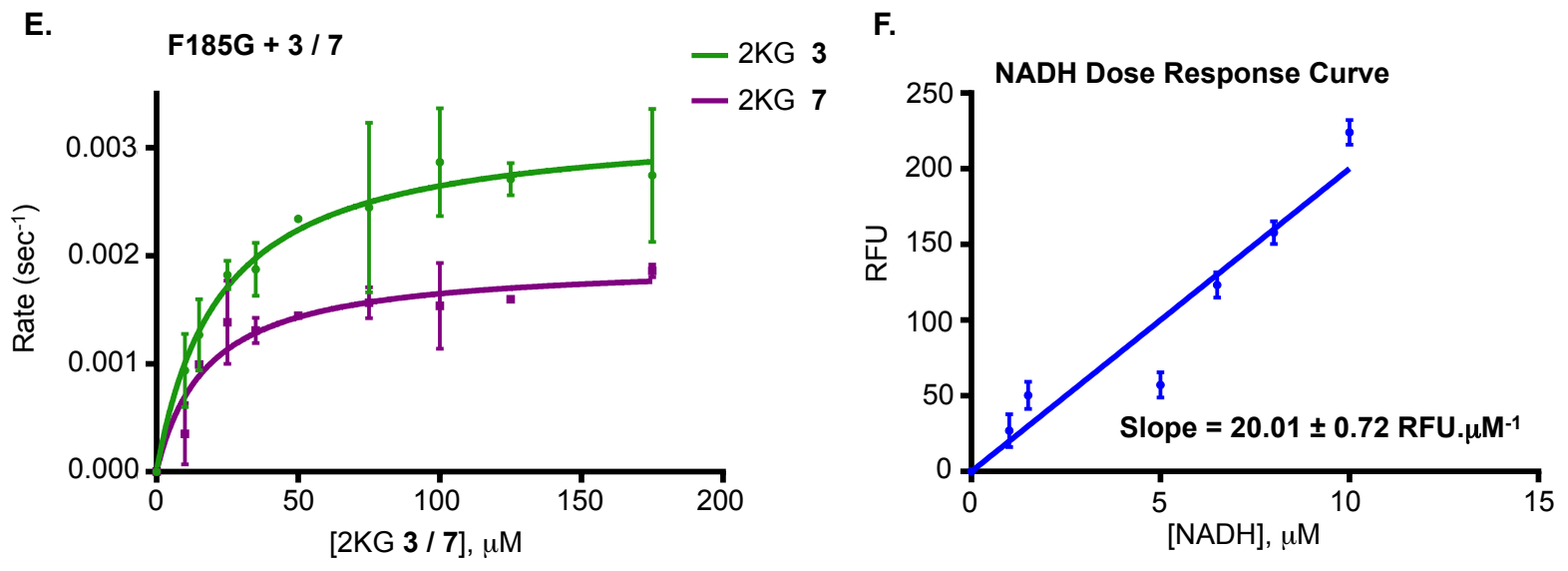

Supplementary Figure S5: Kinetic constants of the wild type and the engineered systems. A, B, C) Time- and $2 \mathrm{KG}$ concentration-dependent increase of $\mathrm{NADH}$ fluorescence intensity as measure of the catalytic activity of wild type KDM4A-1 (A), F185G-3 (B) and F185-7 (C) pairs. D, E) Michaelis-Menten curves for KDM4A-1 (D), F185G-3 and F185-7 (E) pairs to determine the kinetic parameters $\left(k_{\text {cat }}, K_{\mathrm{M}}\right.$ and $\left.k_{\text {cat }} / K_{\mathrm{M}}\right)$. F) NADH dose response curve for correlation between RFU and $\mu \mathrm{M}$ of NADH produced. 
A.

\begin{tabular}{|c|c|c|c|c|c|}
\hline & $\mathrm{K}_{4} \mathrm{Me}_{3}$ & $\mathrm{~K} \mathrm{Me}_{3}$ & $\mathrm{~K}_{2} 7 \mathrm{Me}_{3}$ & $\mathrm{~K} 36 \mathrm{Me}_{3}$ & $\mathrm{R}^{2} \mathrm{Me}_{2}$ \\
\hline KDM $4 \mathrm{~A}+1$ & & & & & \\
\hline$=185 G+3 / 7$ & & & & & \\
\hline
\end{tabular}

B.
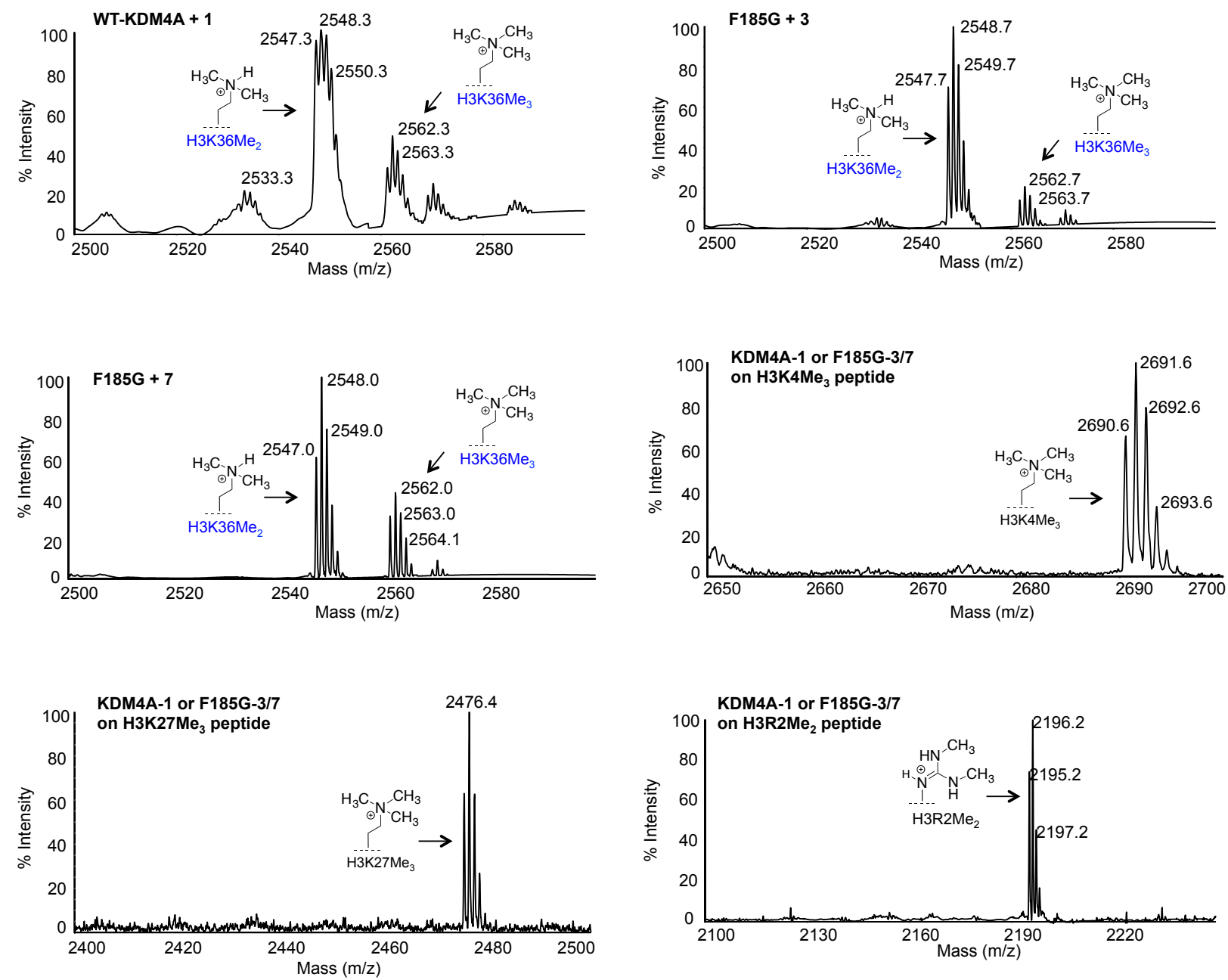

Supplementary Figure S6: Substrate specificity of the wild type and the engineered systems. A) Heat-map diagram showing \% activity of KDM4A-1 and F185G-3/7 pairs towards $\mathrm{H}_{3} \mathrm{KMe}_{3}$, $\mathrm{H} 3 \mathrm{~K}_{9} \mathrm{Me}_{3}, \mathrm{H} 3 \mathrm{~K} 27 \mathrm{Me}_{3}, \mathrm{H} 3 \mathrm{~K} 36 \mathrm{Me}_{3}$ and $\mathrm{H} 3 \mathrm{R} 2 \mathrm{Me}_{2}$ peptides. These results are based on the MALDI-based demethylation assay as shown in B. Activity of KDM4A-1 and F185G-3/7 pairs towards $\mathrm{H} 3 \mathrm{~K}_{9} \mathrm{Me}_{3}$ peptide are shown in Figure $\mathbf{S 3 .}$ 

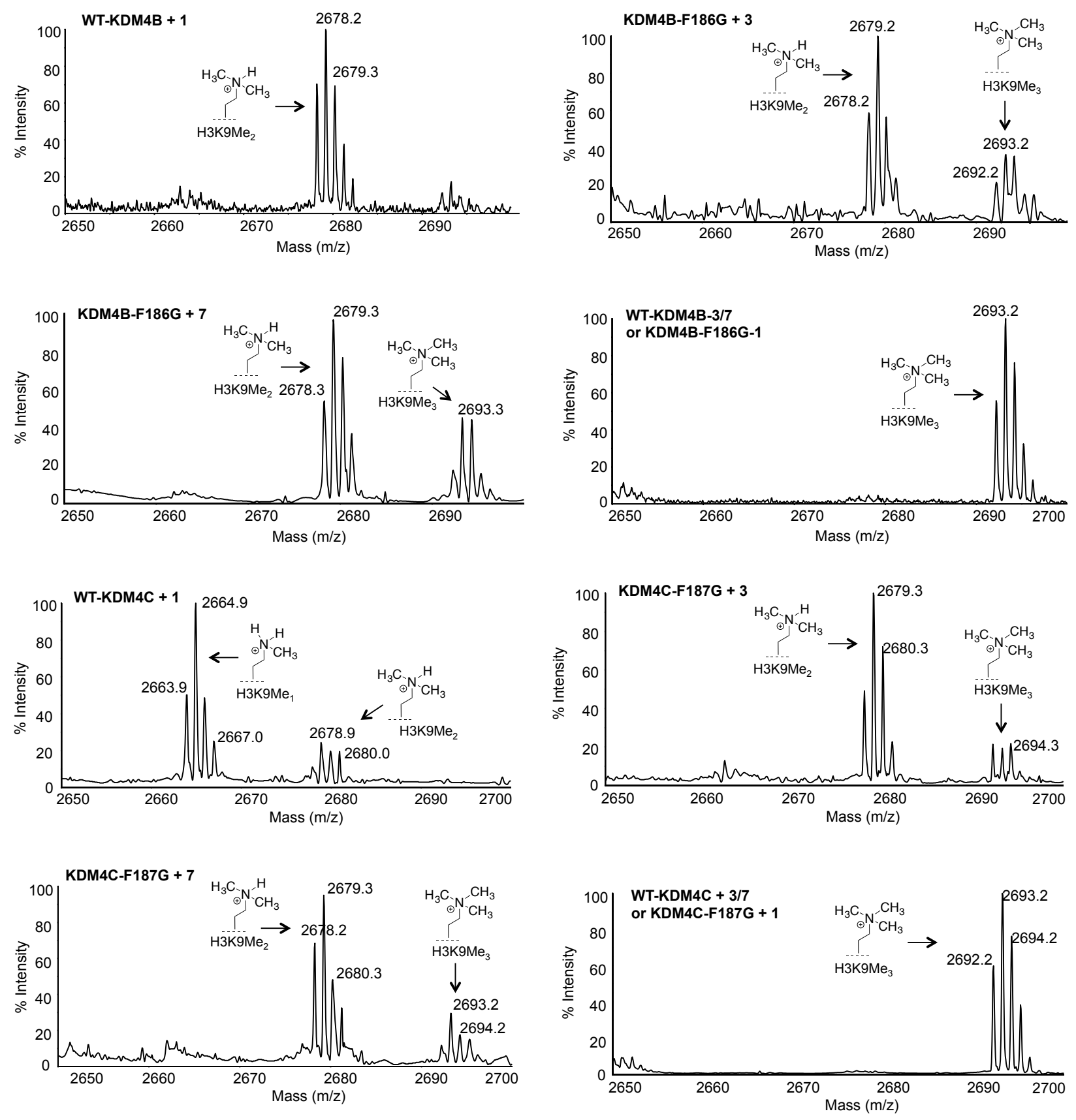

Supplementary Figure S7: Generality of the protein-ligand interface engineering approach. MALDI spectra showing demethylase activity of the wild type KDM4B, KDM4C and KDM4D, and their respective mutants F185G, F187G and F189G (equivalent to KDM4A-F185G) towards $\mathrm{H} 3 \mathrm{~K}_{9} \mathrm{Me}_{3}$ peptide. The figure is continued in the next page. 

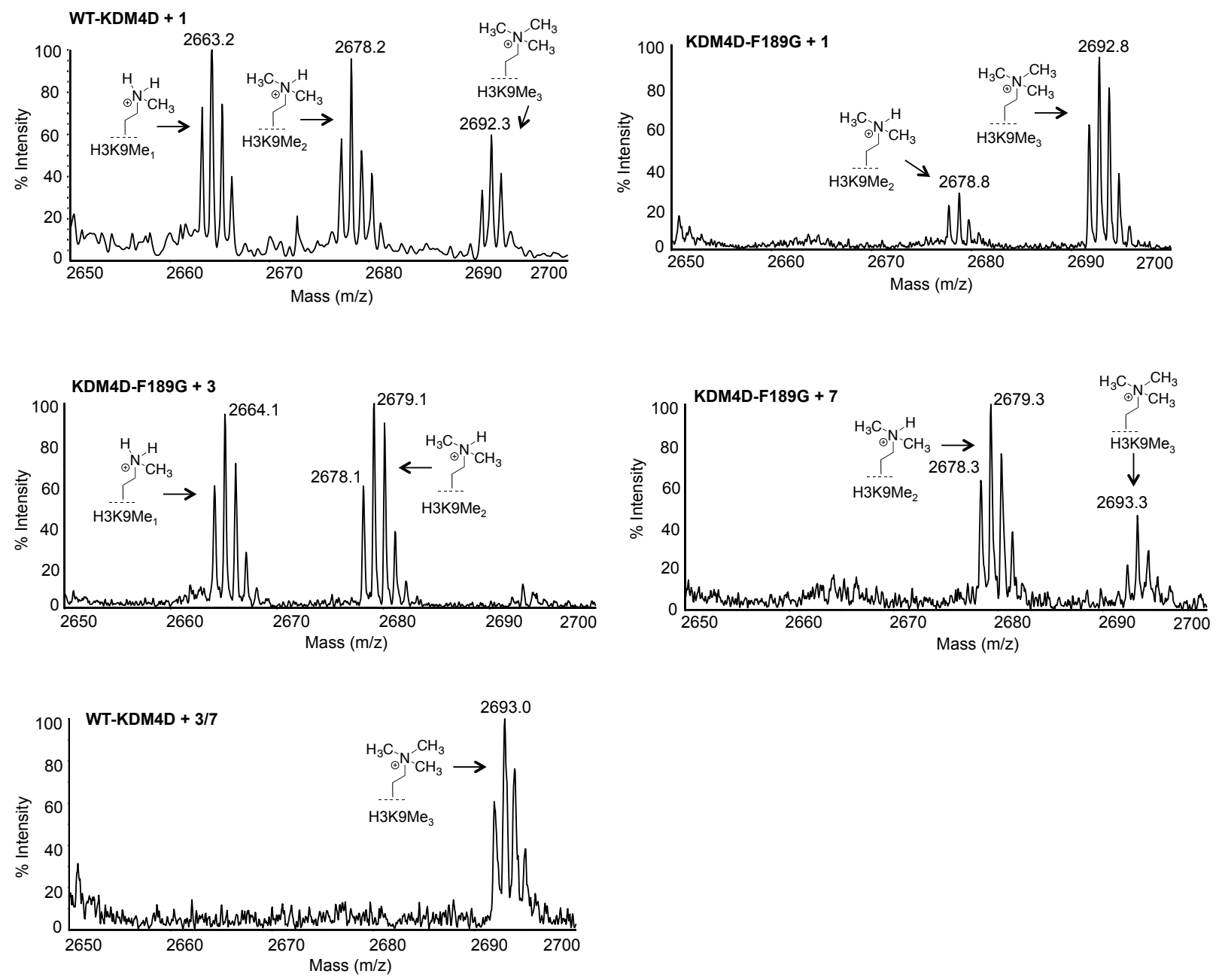

Supplementary Figure S7 continued: Generality of the protein-ligand interface engineering approach. MALDI spectra showing demethylase activity of the wild type KDM4B, KDM4C and KDM4D, and their respective mutants F185G, F187G and F189G (equivalent to KDM4AF185G) towards $\mathrm{H} 3 \mathrm{~K} 9 \mathrm{Me}_{3}$ peptide. 
A.

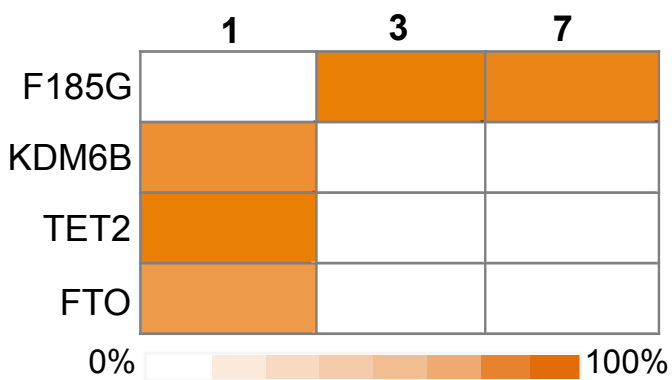

B.
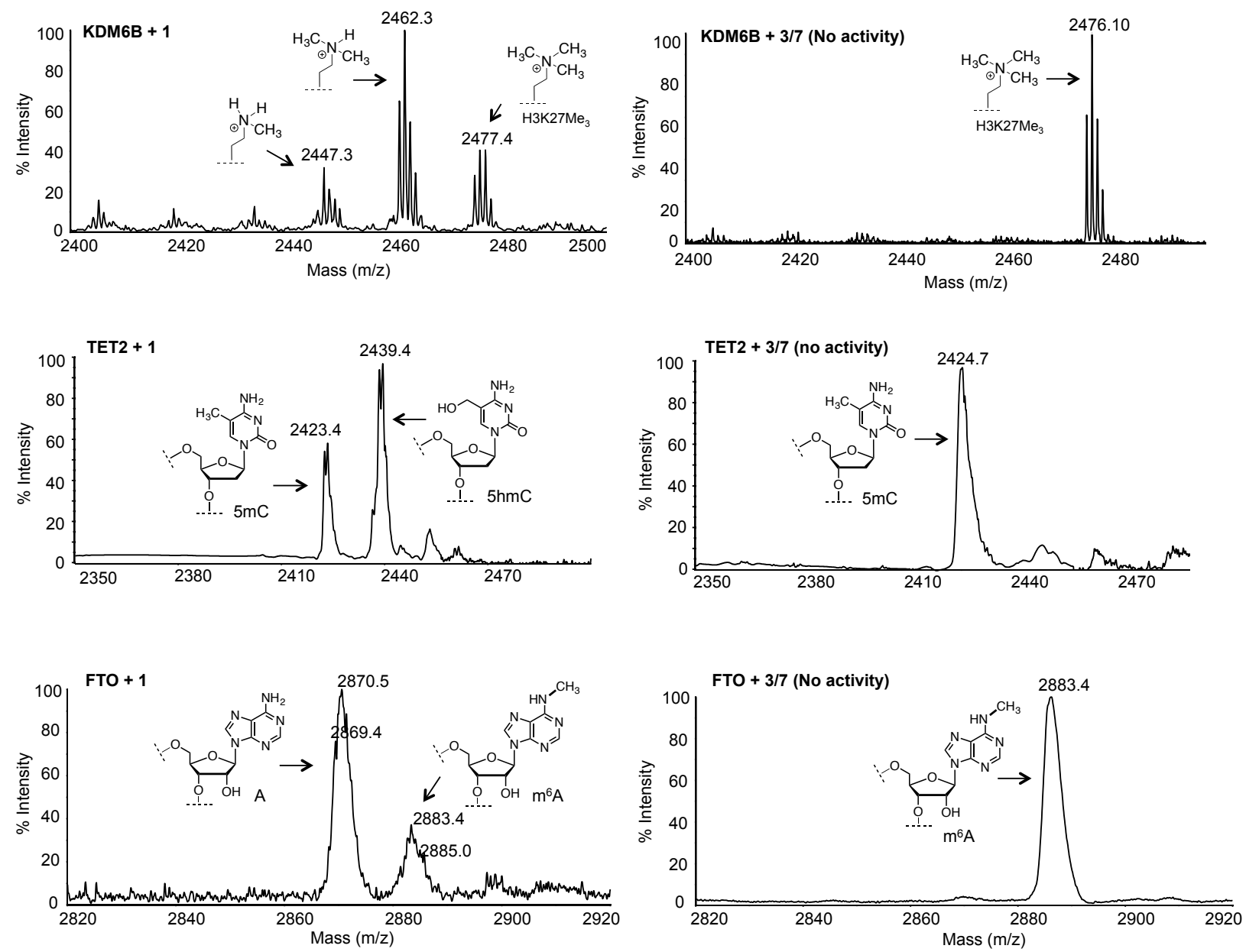

Supplementary Figure S8: Orthogonality of $2 \mathrm{KG}$ analogues 3 and 7. A) Heat-map diagram showing \% activity of wild type KDM6B, TET2 and FTO pairs towards their respective substrates (H3K27 $\mathrm{Me}_{3}, 5 \mathrm{mC}-\mathrm{DNA}$ and m6A-RNA, respectively) when paired up with cofactors 1, 3 and 7). Sequences of these substrates are given in Table S1. The heat-map diagram is based on the MALDI-based demethylation assay as shown in B. Activity of F185G-3/7 pairs towards $\mathrm{H} 3 \mathrm{~K}_{9} \mathrm{Me}_{3}$ peptide is shown in Figure S3. 

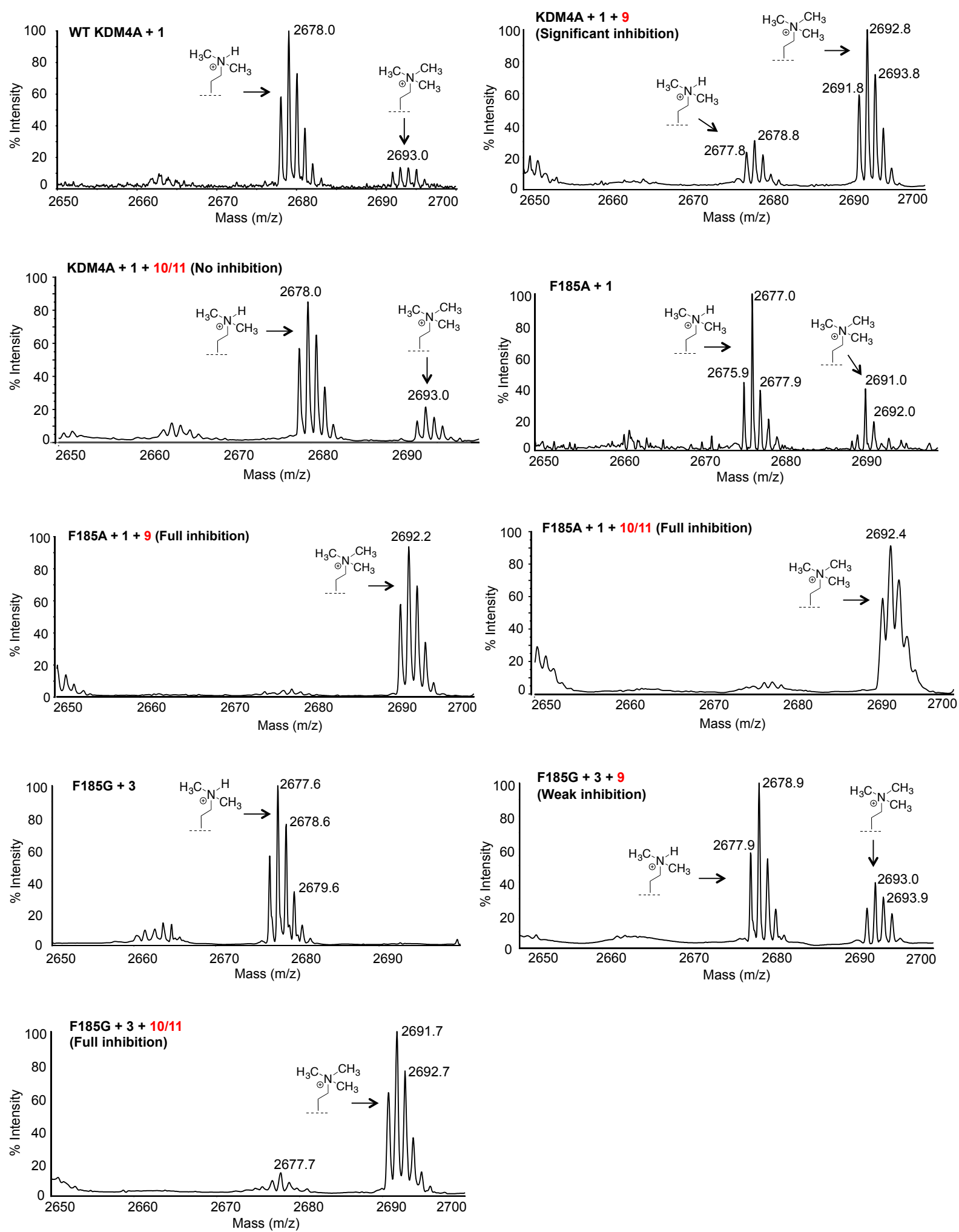

Supplementary Figure S9: Allele-specific inhibition of KDM4A. MALDI spectra showing inhibition of wild type KDM4A by 2HG 9 but not by the 'bumped' analogues $\mathbf{1 0}$ and $\mathbf{1 1}$ which inhibit only F185A and F185G mutants with expanded active sites. 
A.

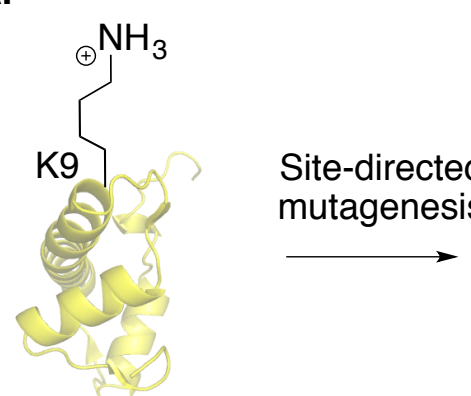

Wild type H3

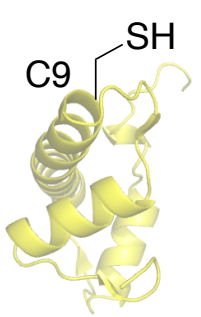

H3 K9C
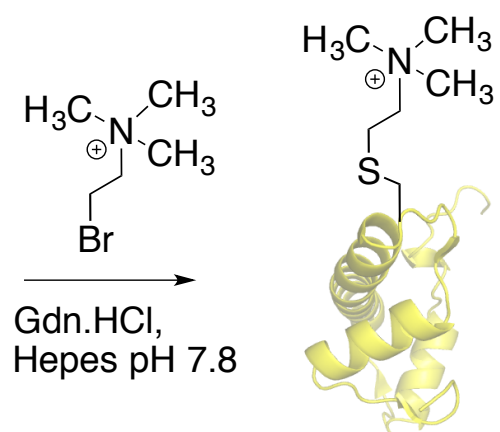

$\mathrm{H} 3 \mathrm{~K}_{\mathrm{C}} 9 \mathrm{Me}_{3}$

B.

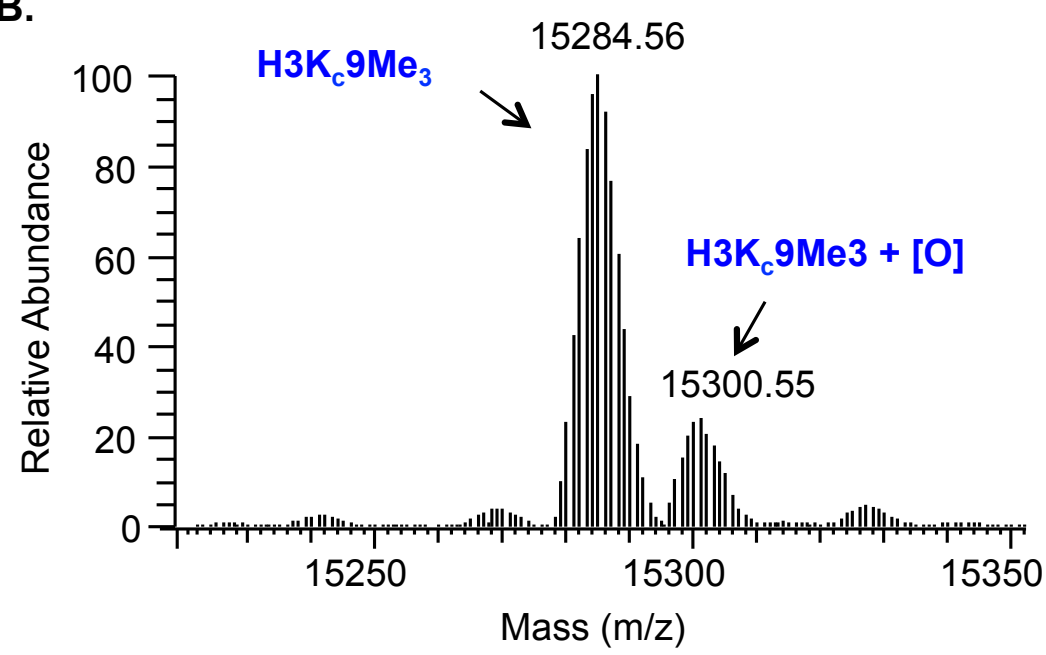

Supplementary Figure S10: Synthesis and demethylation of full-length $\mathrm{H}_{3} \mathrm{~K}_{\mathrm{C}} 9 \mathrm{Me}_{3}$. A) Method to site-specifically introduce trimethylthialysine in histone $\mathrm{H} 3 .{ }^{10,11}$ In this approach a cysteine was introduced at position 9 using site-directed mutagenesis. Sulfhydryl group in H3K9C was then reacted with (2-bromoethyl)trimethyl ammonium bromide to install the required modification. B) ESI LC-MS spectrum showing installation of the required modification on histone H3 along with a minor oxidized side product. 


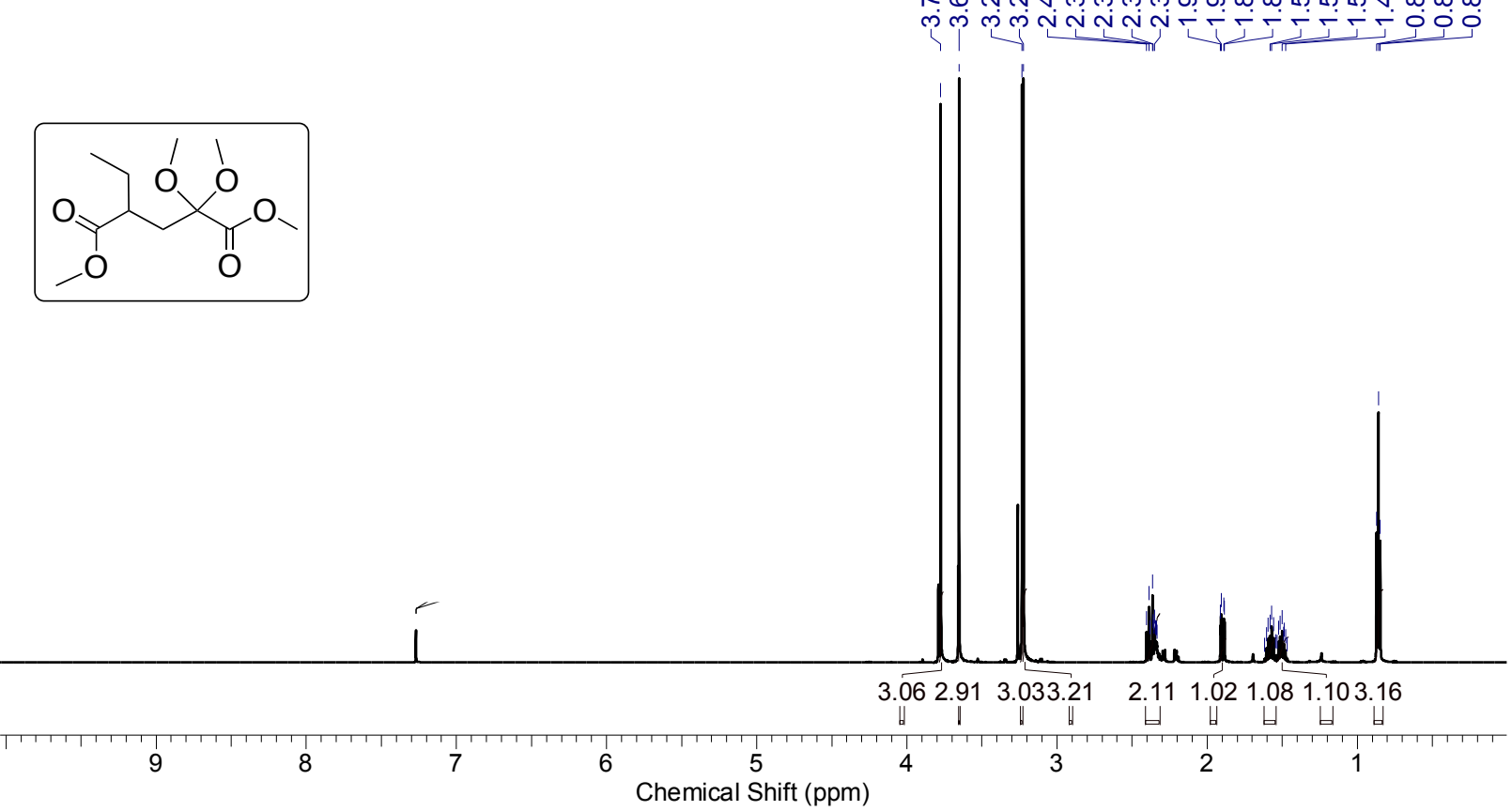

dd-2kg-2c.002.001.1r.esp
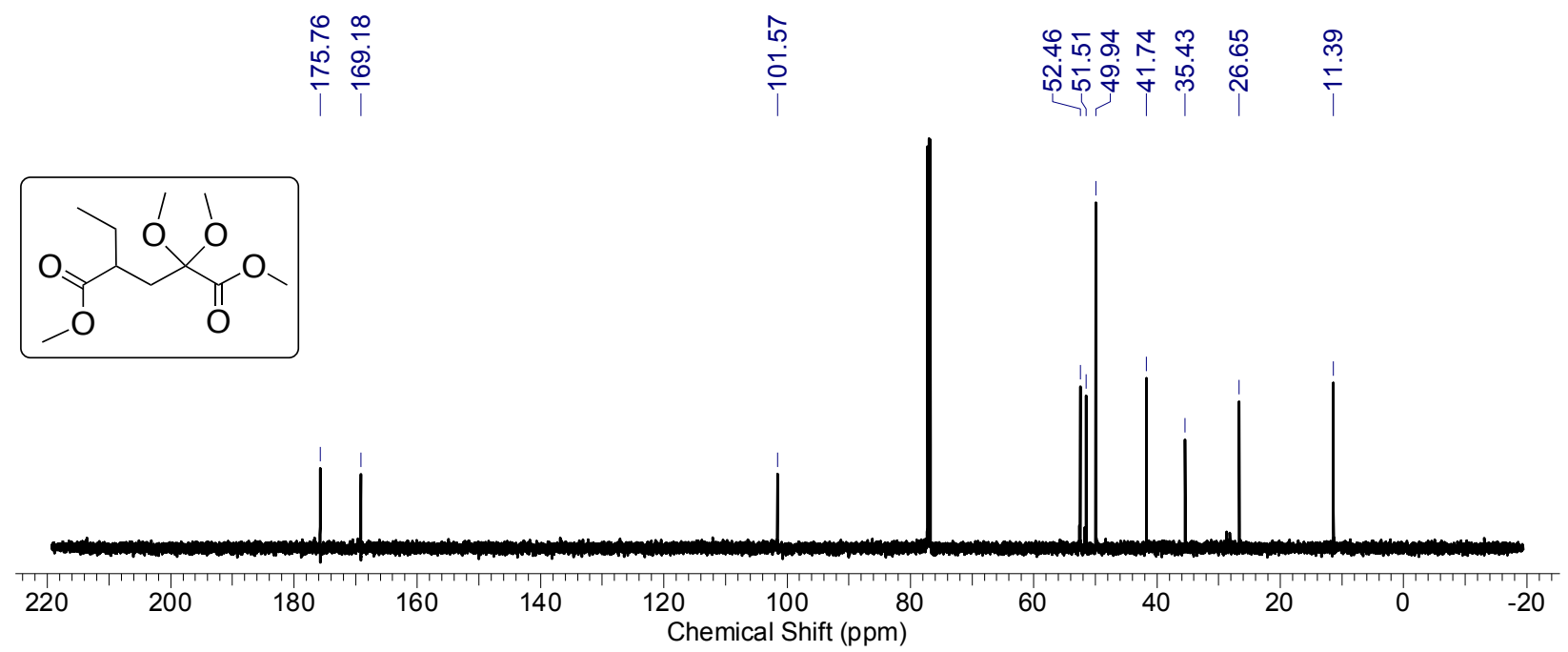

Supplementary Figure S11: ${ }^{1} \mathrm{H}$ and ${ }^{13} \mathrm{C}$ NMR spectrum of the boxed compound in $\mathrm{CDCl}_{3}$. 


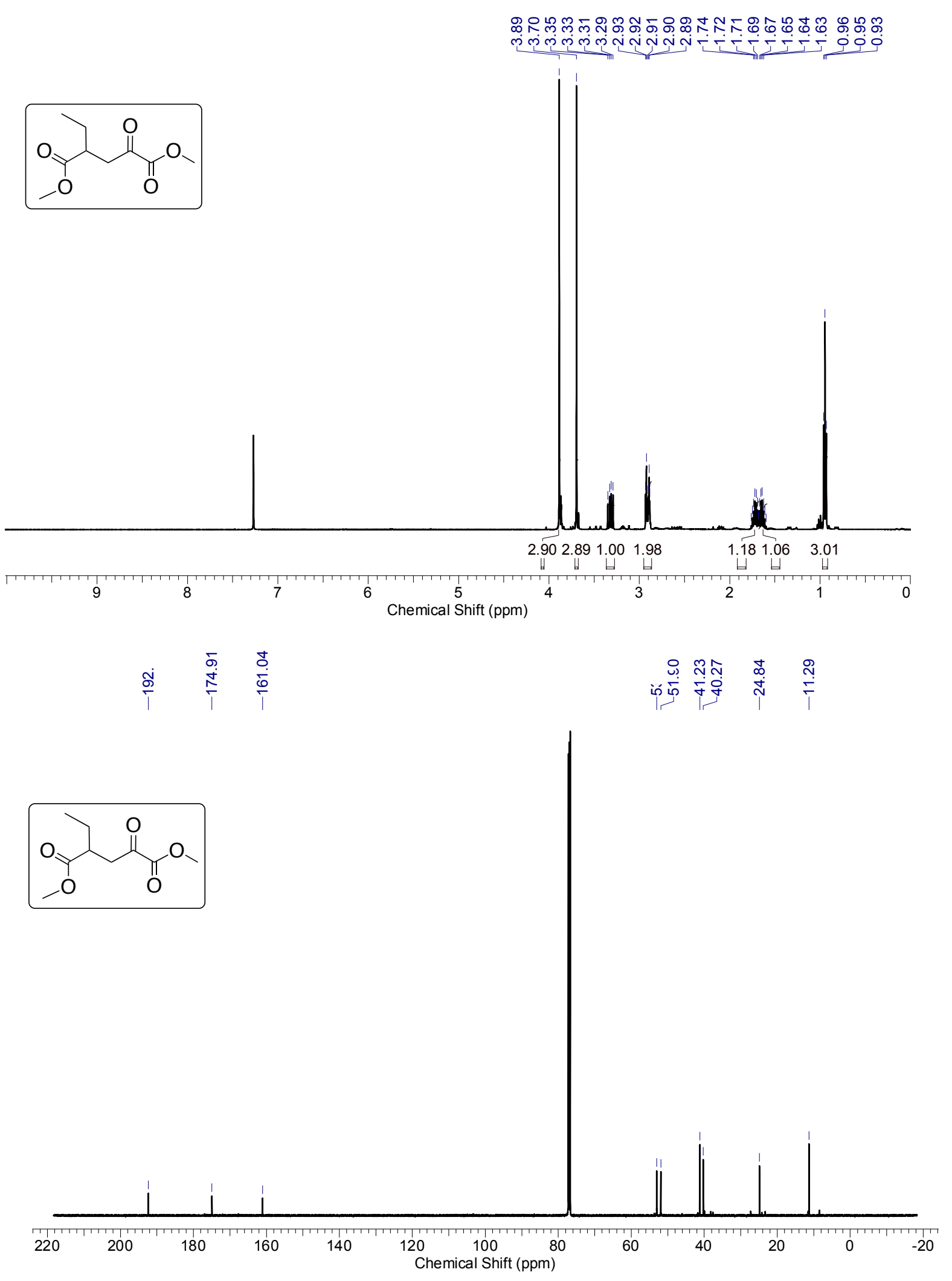

Supplementary Figure S12: ${ }^{1} \mathrm{H}$ and ${ }^{13} \mathrm{C}$ NMR spectrum of the boxed compound in $\mathrm{CDCl}_{3}$. 

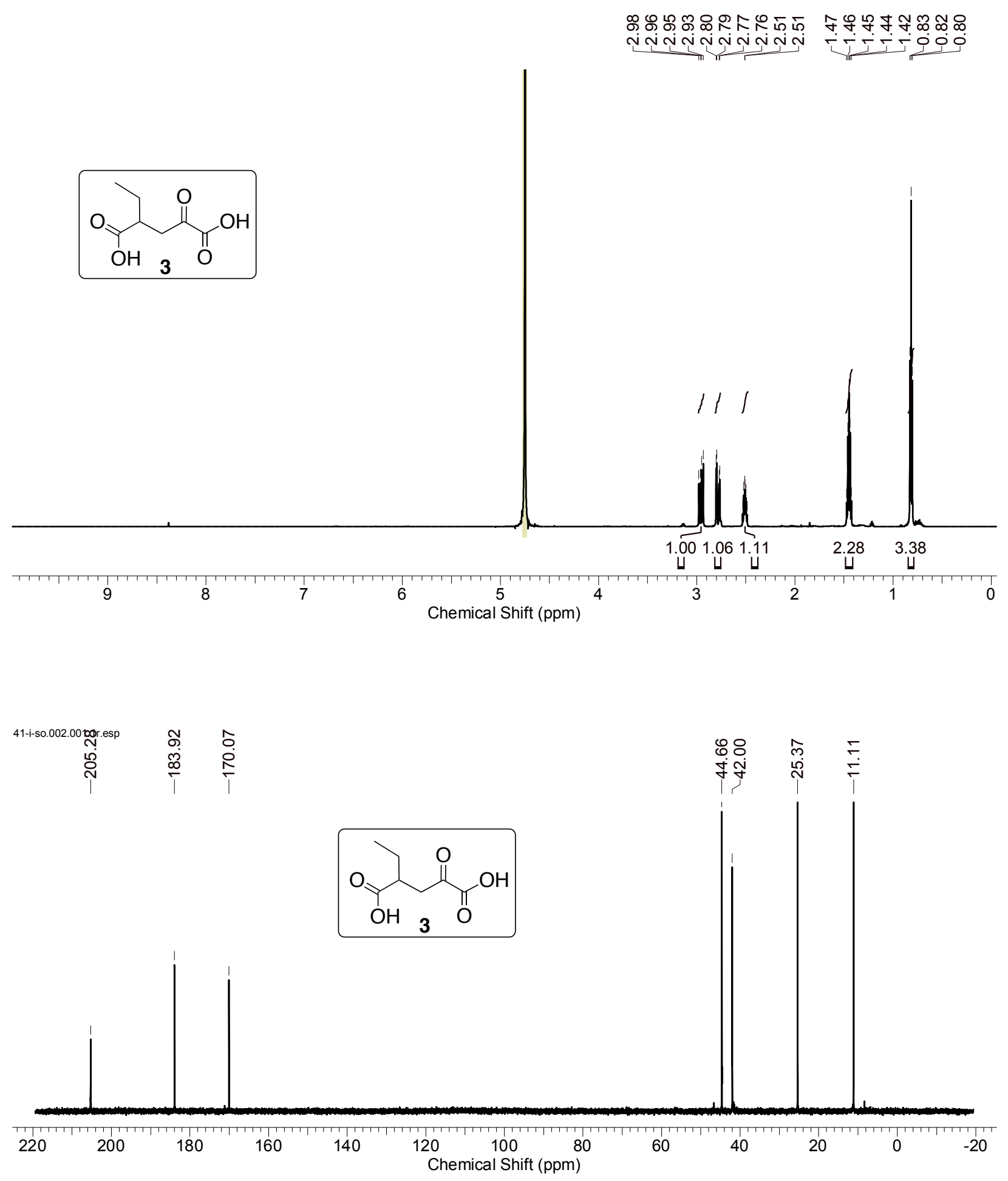

Supplementary Figure S13: ${ }^{1} \mathrm{H}$ and ${ }^{13} \mathrm{C}$ NMR spectrum of $2 \mathrm{KG}$ analogue 3 in $\mathrm{D}_{2} \mathrm{O}$. 

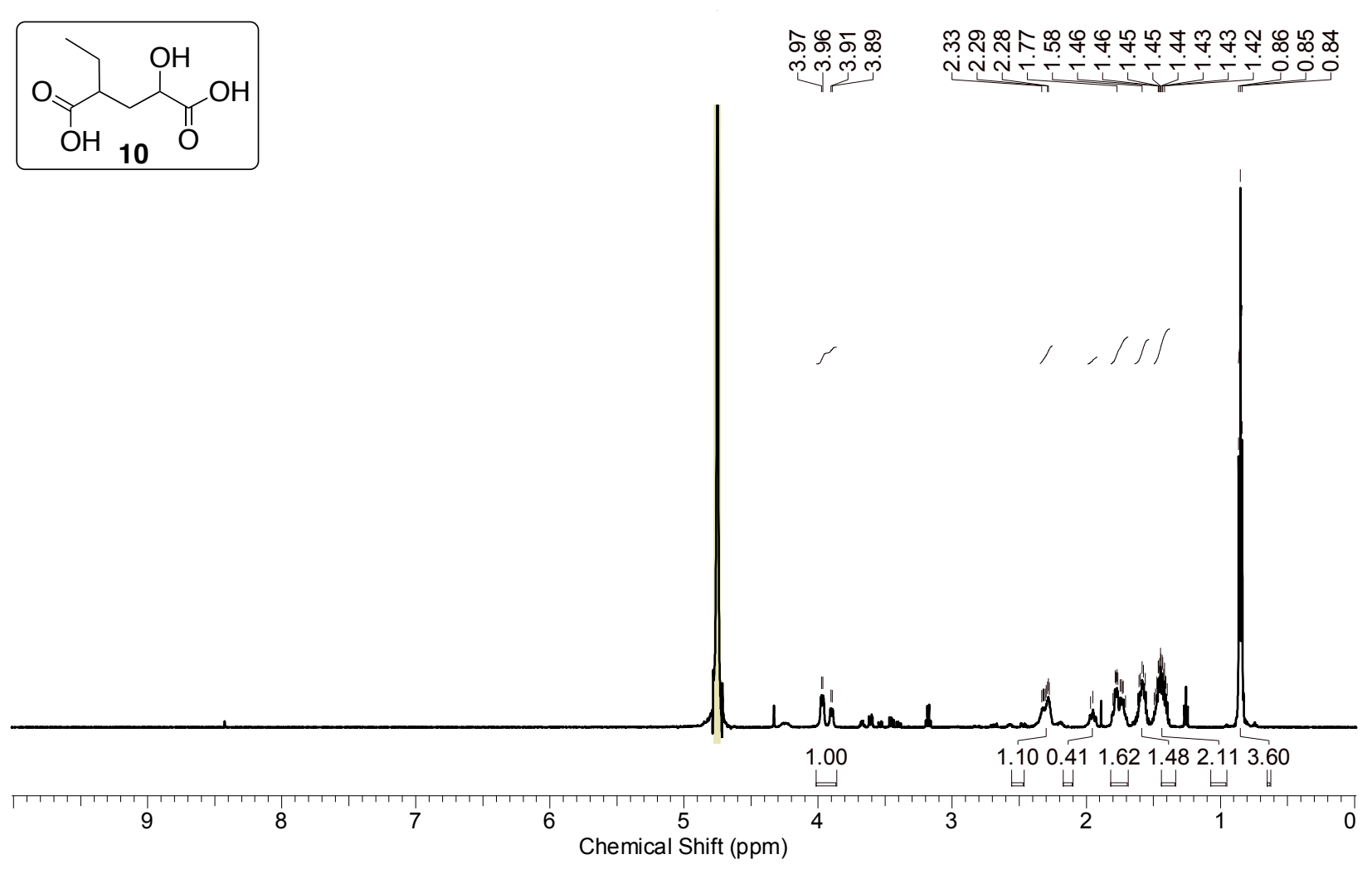

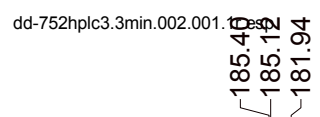
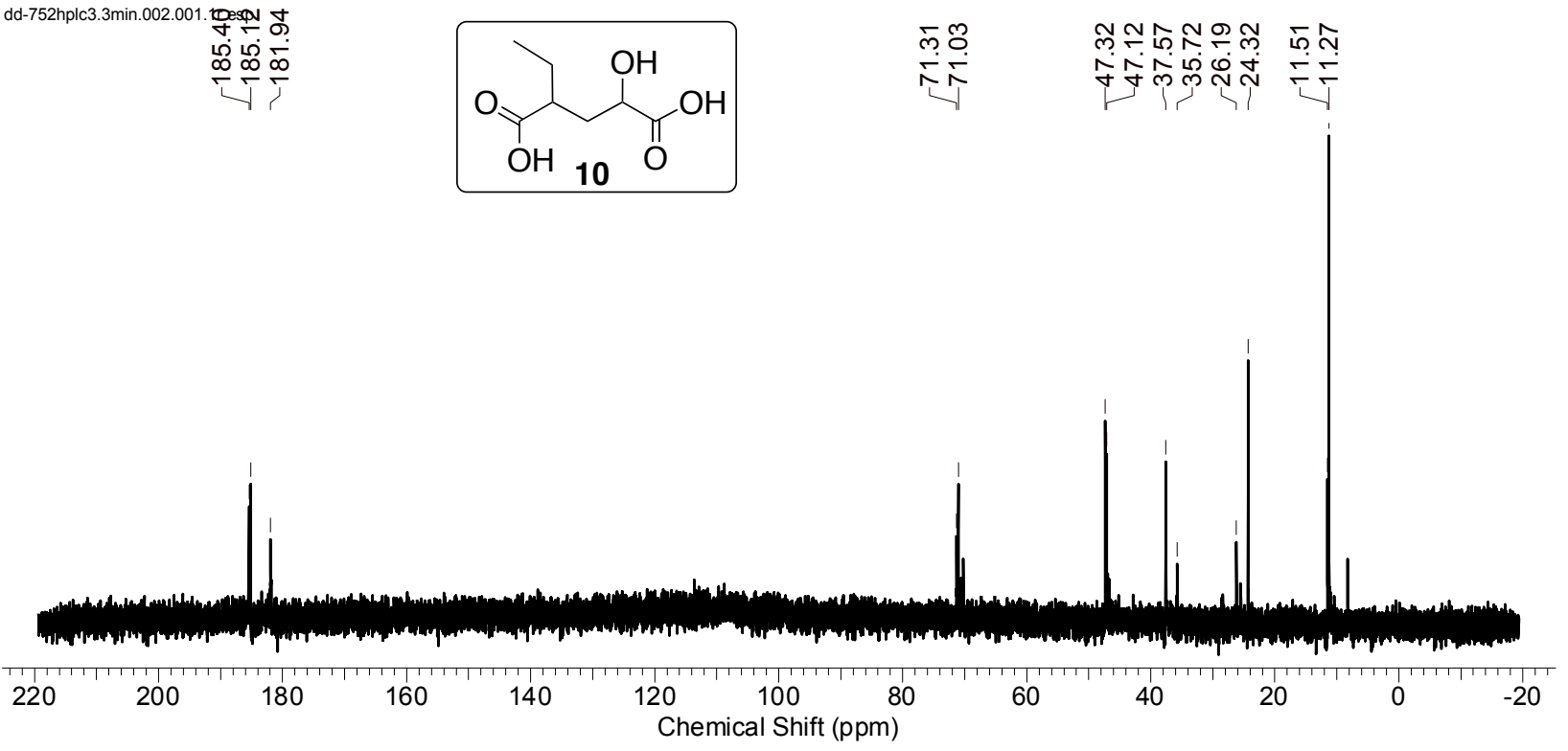

Supplementary Figure S14: ${ }^{1} \mathrm{H}$ and ${ }^{13} \mathrm{C}$ NMR spectrum of $2 \mathrm{HG}$ analogue 10 in $\mathrm{D}_{2} \mathrm{O}$. 


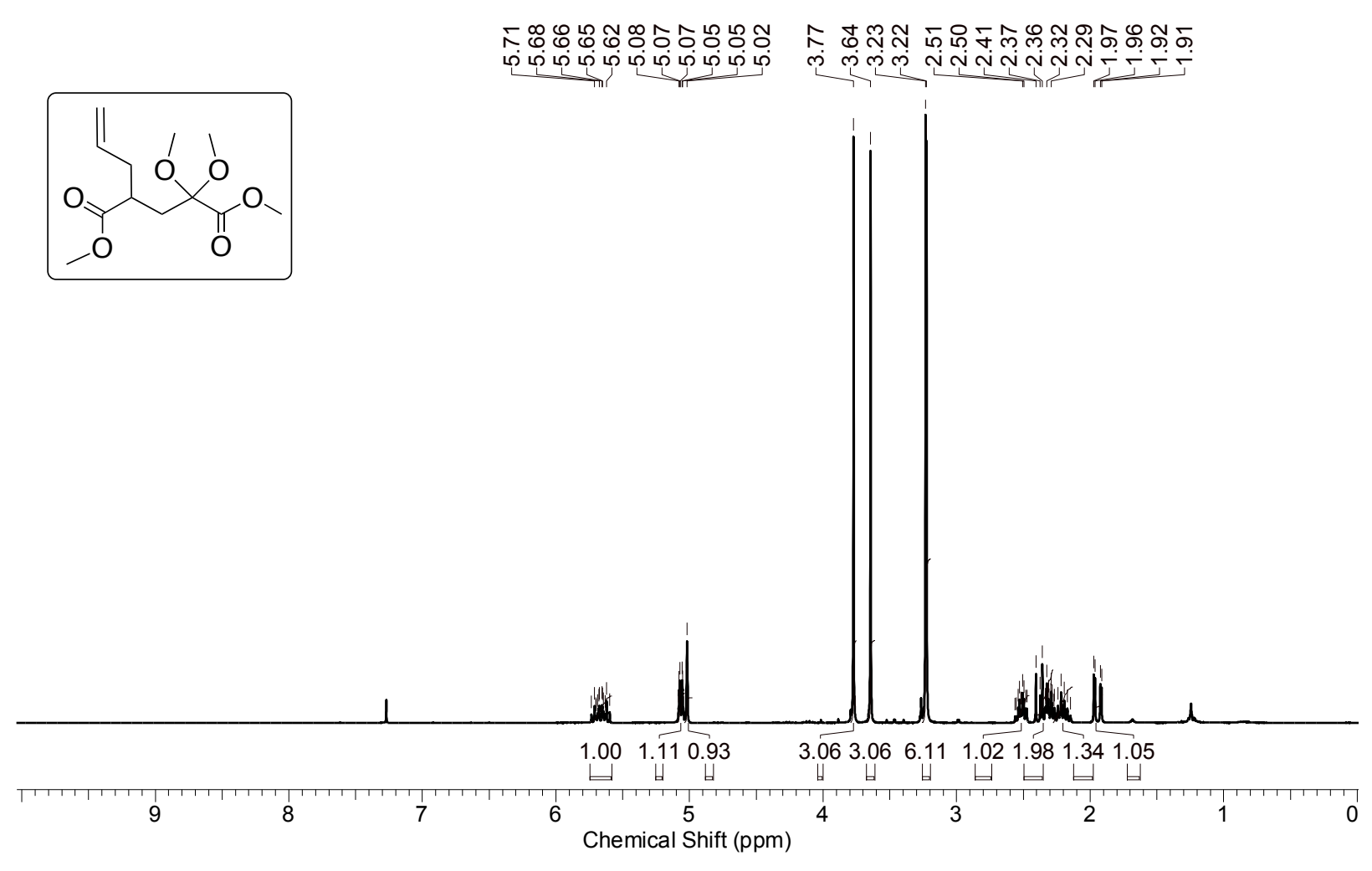

dd-03082014har.012.00

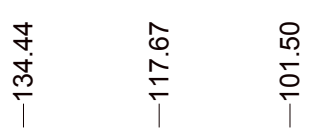

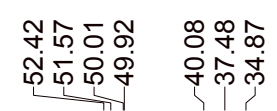
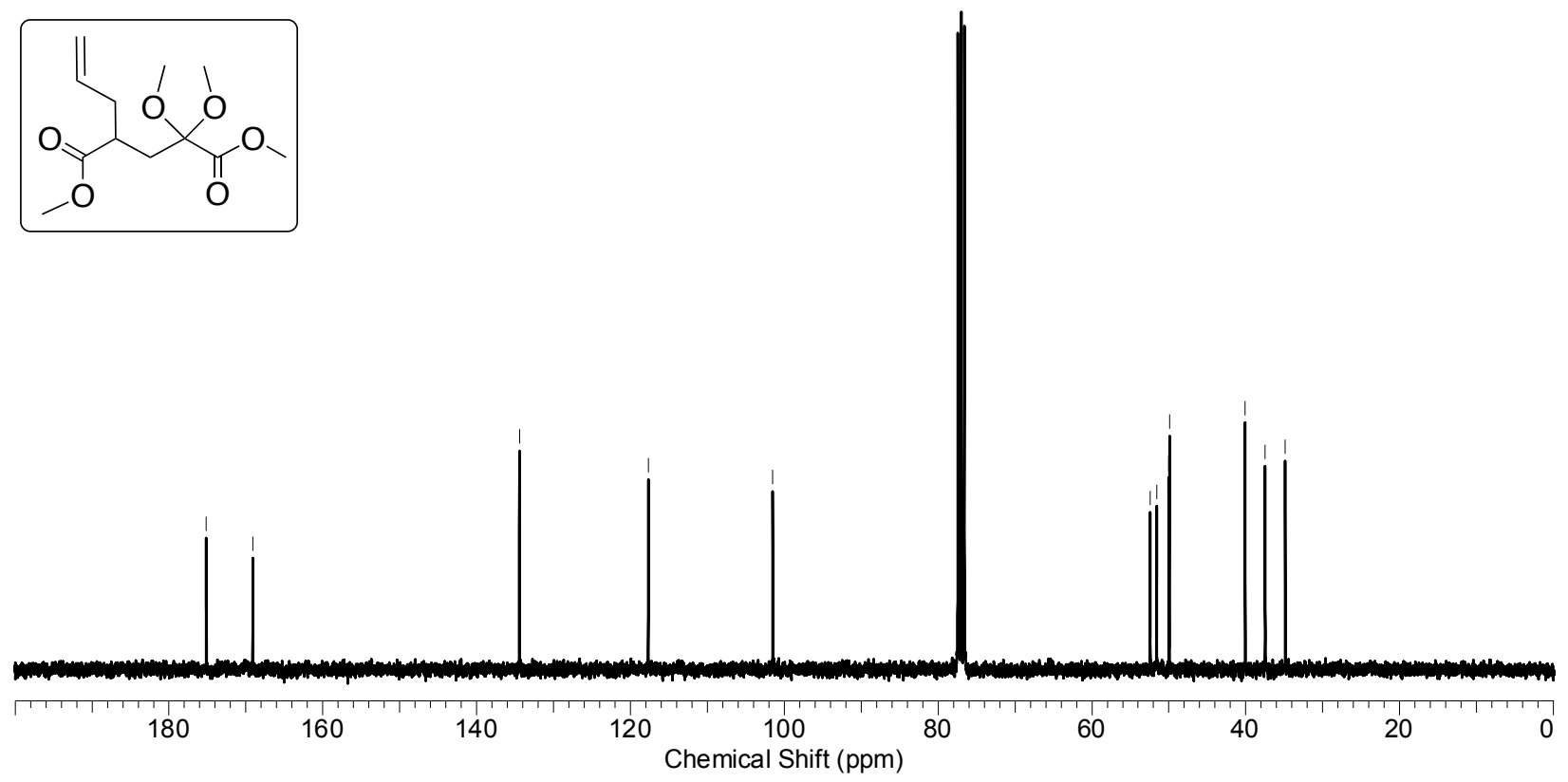

Supplementary Figure S15: ${ }^{1} \mathrm{H}$ and ${ }^{13} \mathrm{C}$ NMR spectrum of the boxed compound in $\mathrm{CDCl}_{3}$. 

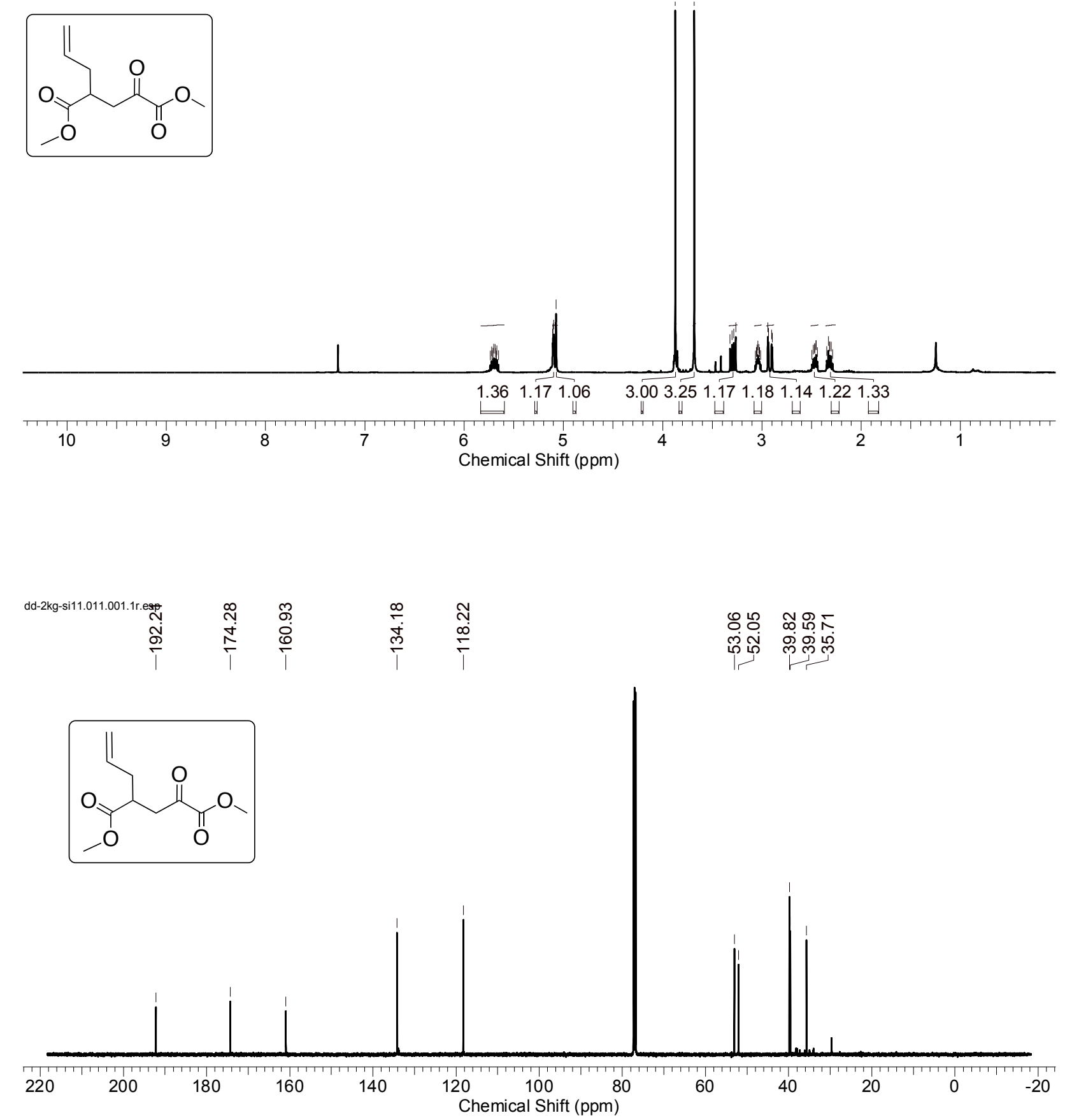

Supplementary Figure S16: ${ }^{1} \mathrm{H}$ and ${ }^{13} \mathrm{C}$ NMR spectrum of the boxed compound in $\mathrm{CDCl}_{3}$. 


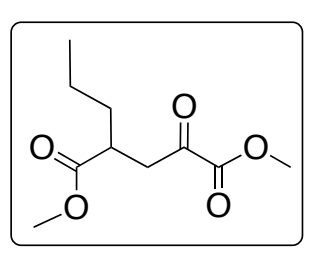

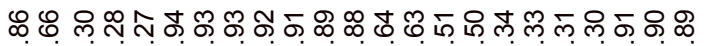

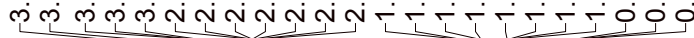

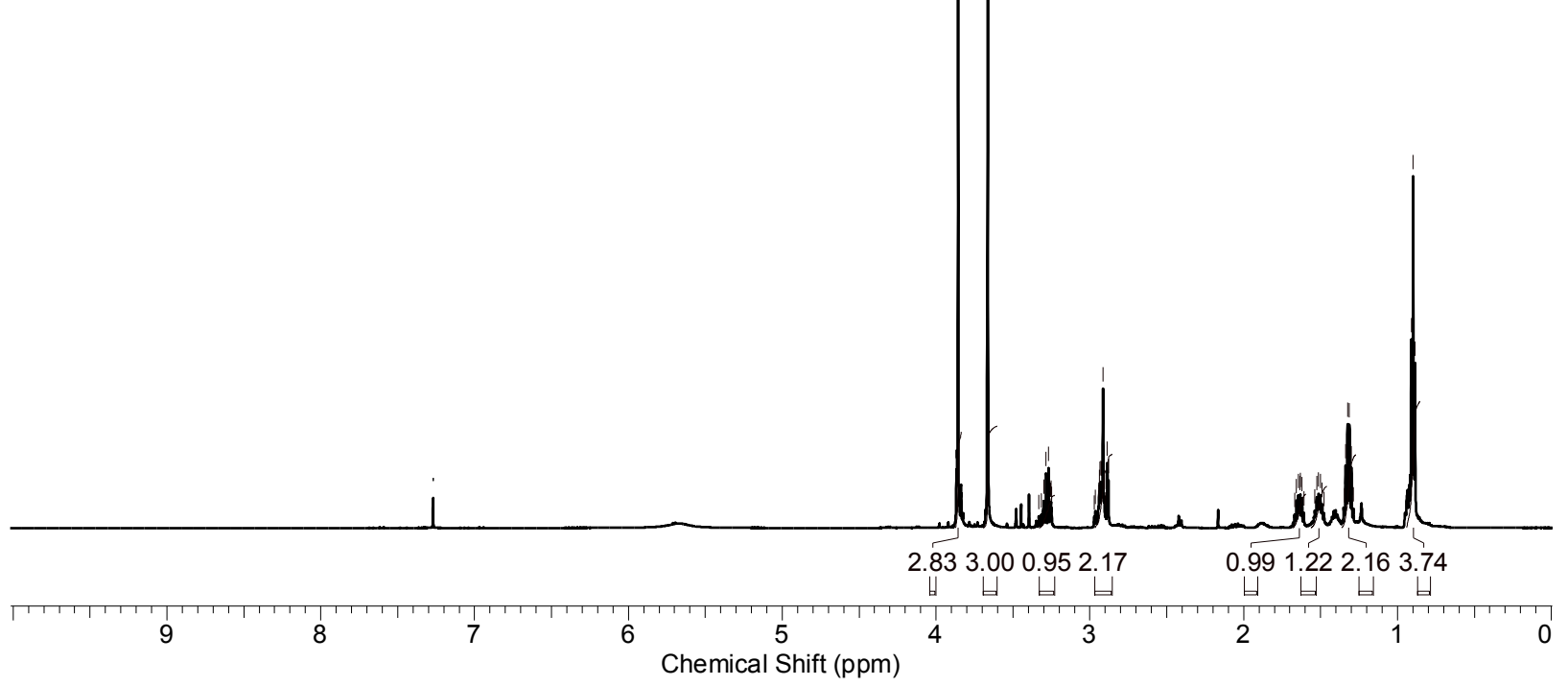

dd-2kg-3b.002.001.1r.esp
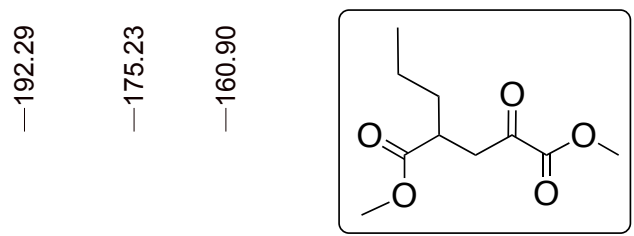

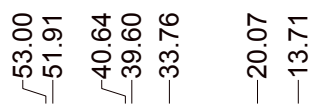

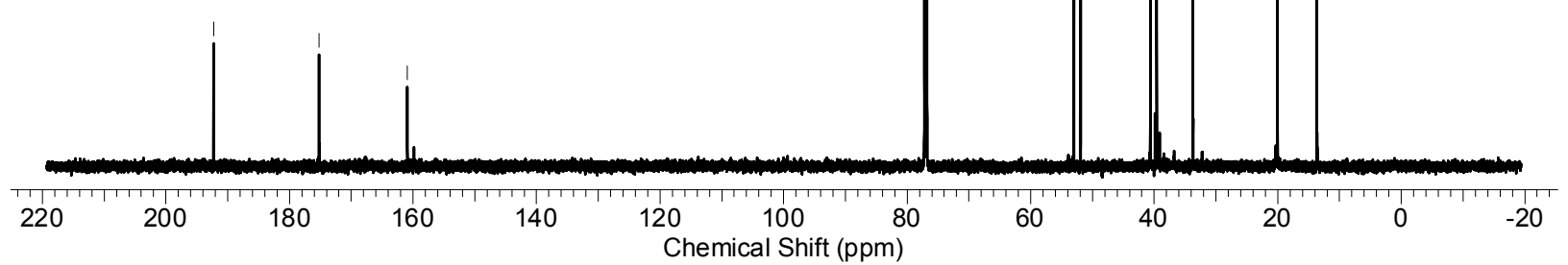

Supplementary Figure S17: ${ }^{1} \mathrm{H}$ and ${ }^{13} \mathrm{C}$ NMR spectrum of the boxed compound in $\mathrm{CDCl}_{3}$. 
<smiles>CCCCC(CC(=O)C(=O)O)C(=O)O</smiles>
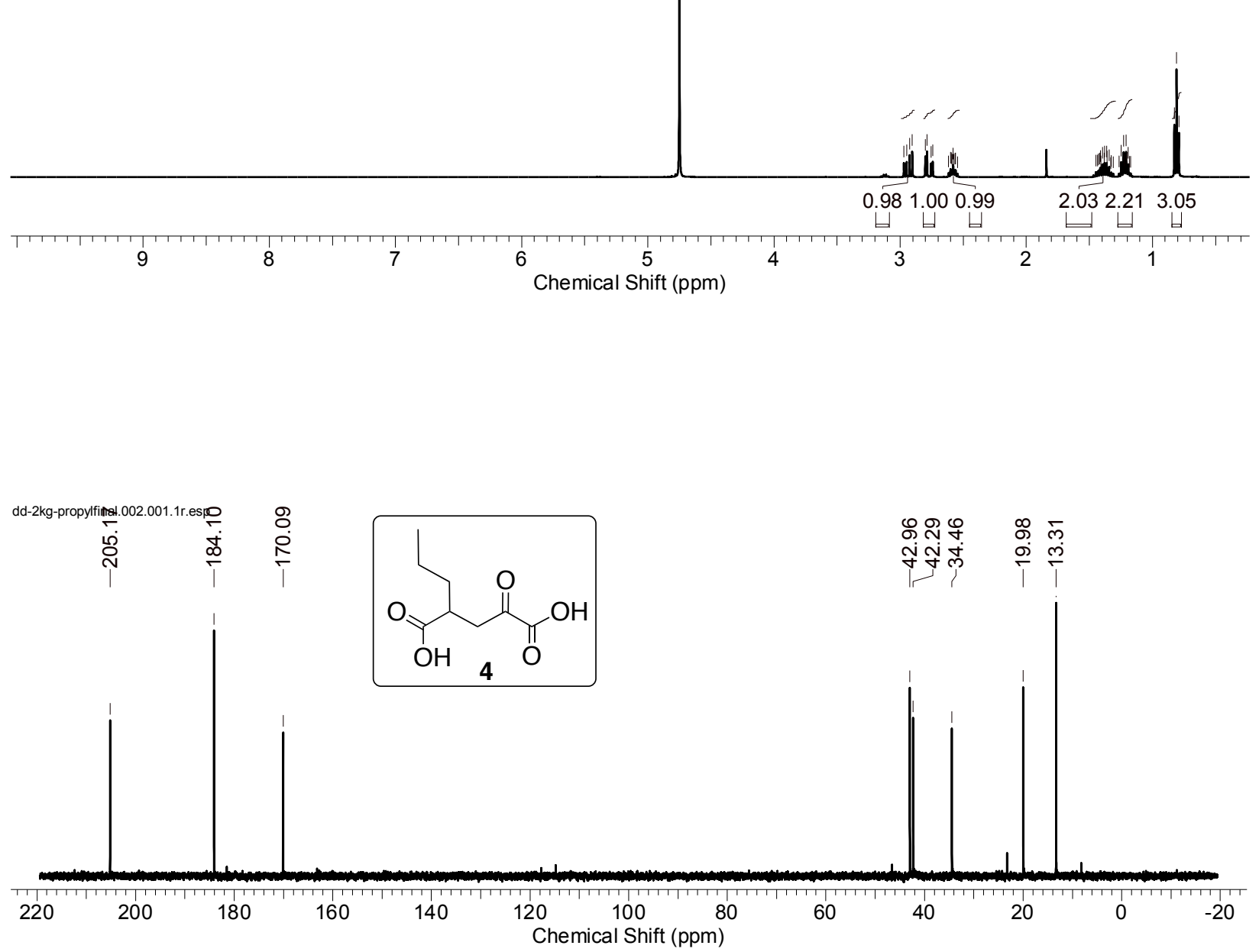

Supplementary Figure S18: ${ }^{1} \mathrm{H}$ and ${ }^{13} \mathrm{C}$ NMR spectrum of $2 \mathrm{KG}$ analogue 4 in $\mathrm{D}_{2} \mathrm{O}$. 


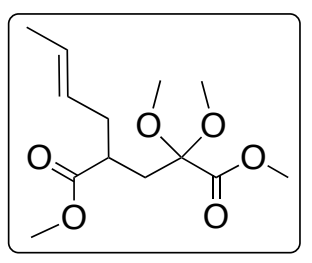

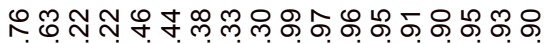

من

एंगु
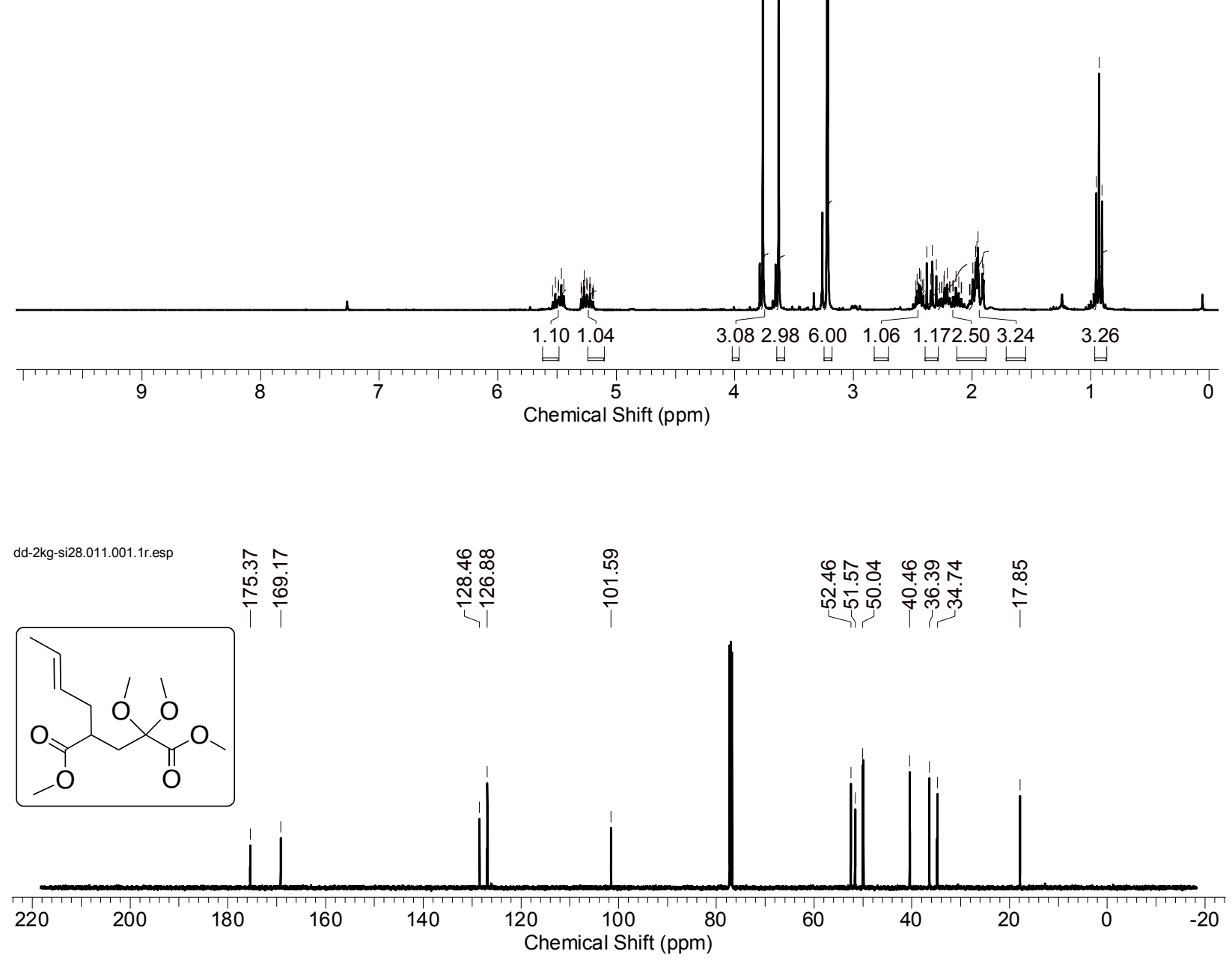

Supplementary Figure S19: ${ }^{1} \mathrm{H}$ and ${ }^{13} \mathrm{C}$ NMR spectrum of the boxed compound in $\mathrm{CDCl}_{3}$. 
<smiles>CCCCC(CC(OC)(OC)C(=O)OCC)C(=O)OC</smiles>
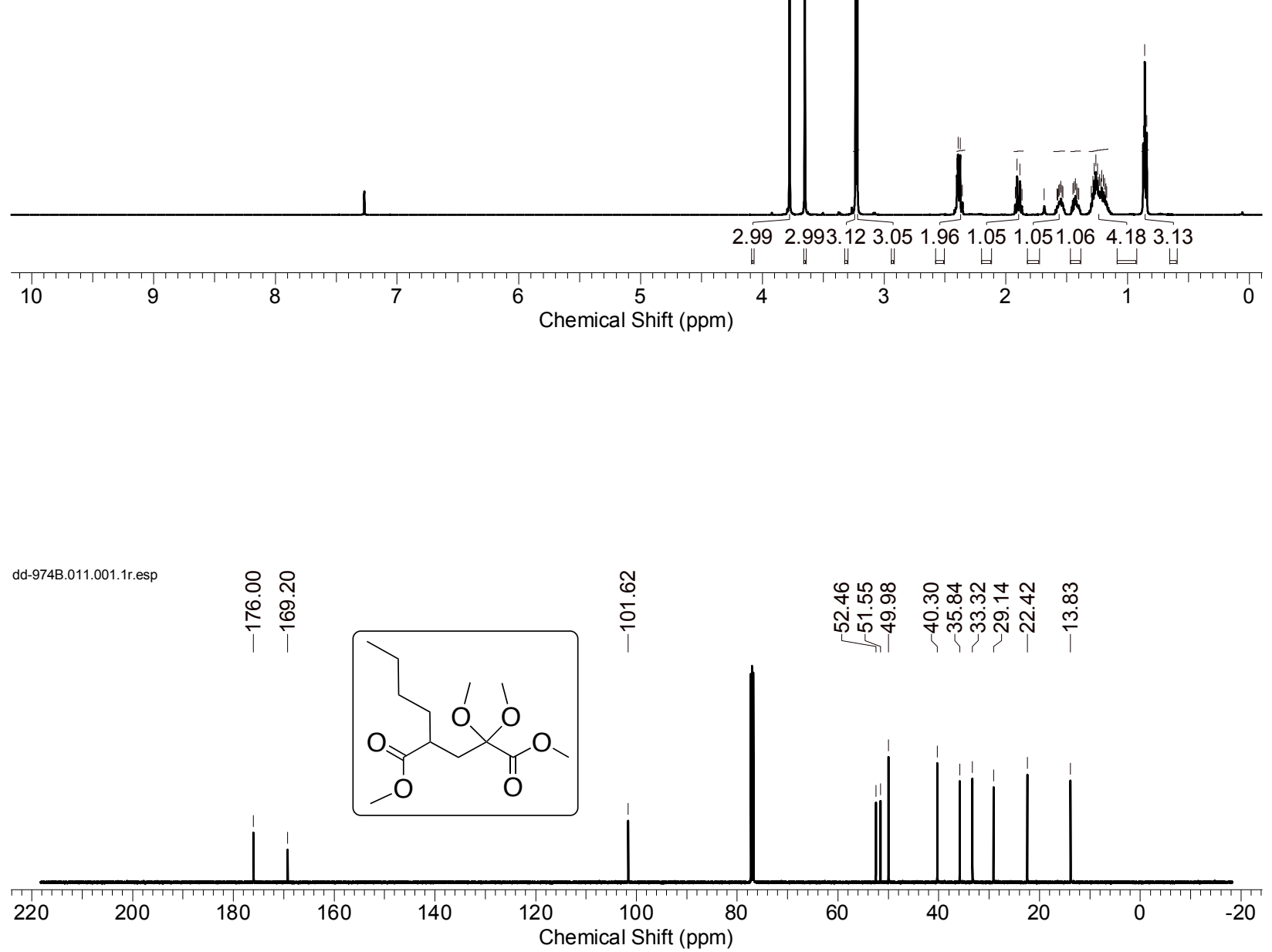

Supplementary Figure S20: ${ }^{1} \mathrm{H}$ and ${ }^{13} \mathrm{C}$ NMR spectrum of the boxed compound in $\mathrm{CDCl}_{3}$. 

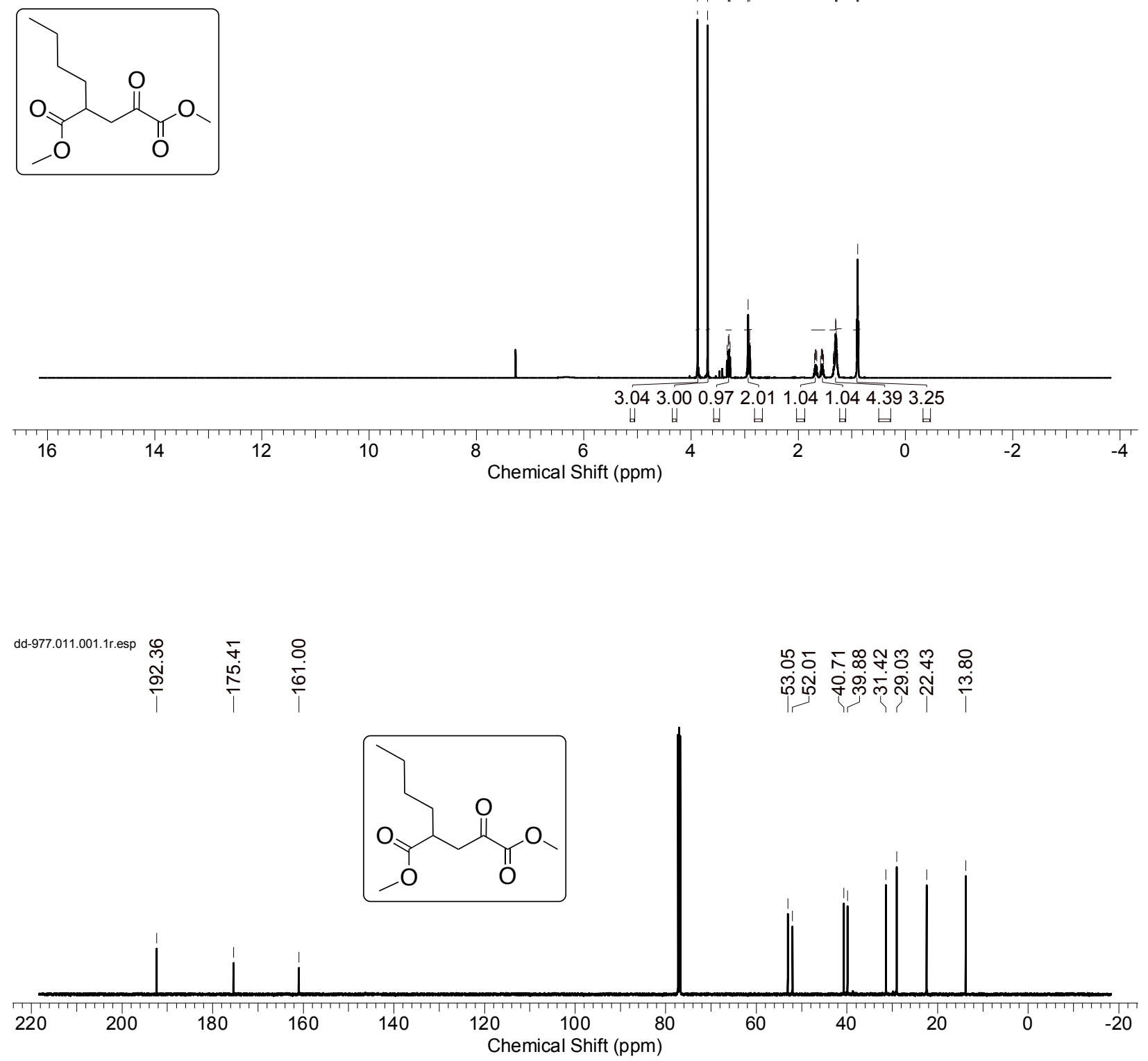

Supplementary Figure S21: ${ }^{1} \mathrm{H}$ and ${ }^{13} \mathrm{C}$ NMR spectrum of the boxed compound in $\mathrm{CDCl}_{3}$. 

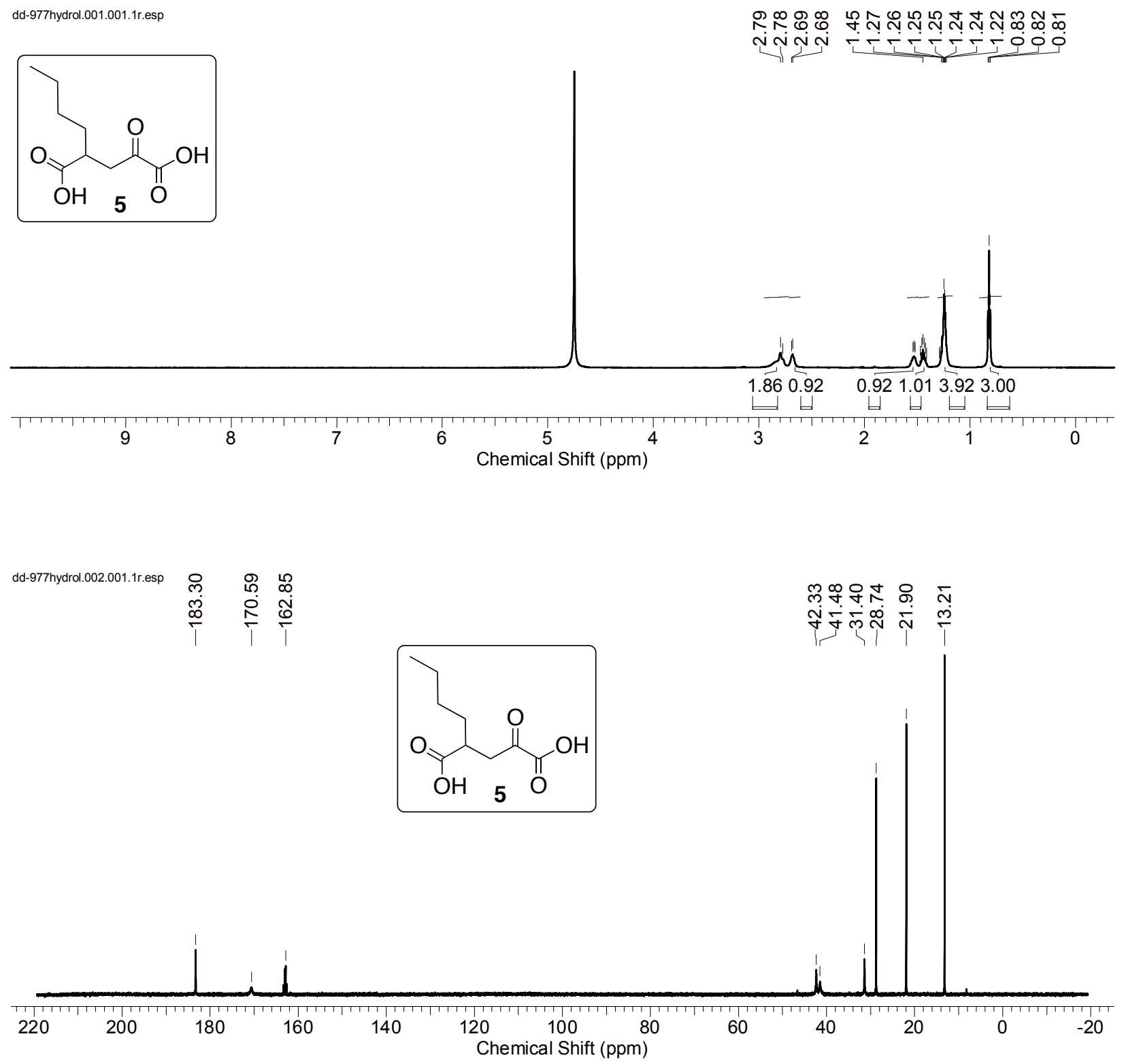

Supplementary Figure S22: ${ }^{1} \mathrm{H}$ and ${ }^{13} \mathrm{C}$ NMR spectrum of $2 \mathrm{KG}$ analogue 5 in $\mathrm{D}_{2} \mathrm{O}$. 


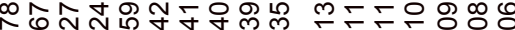
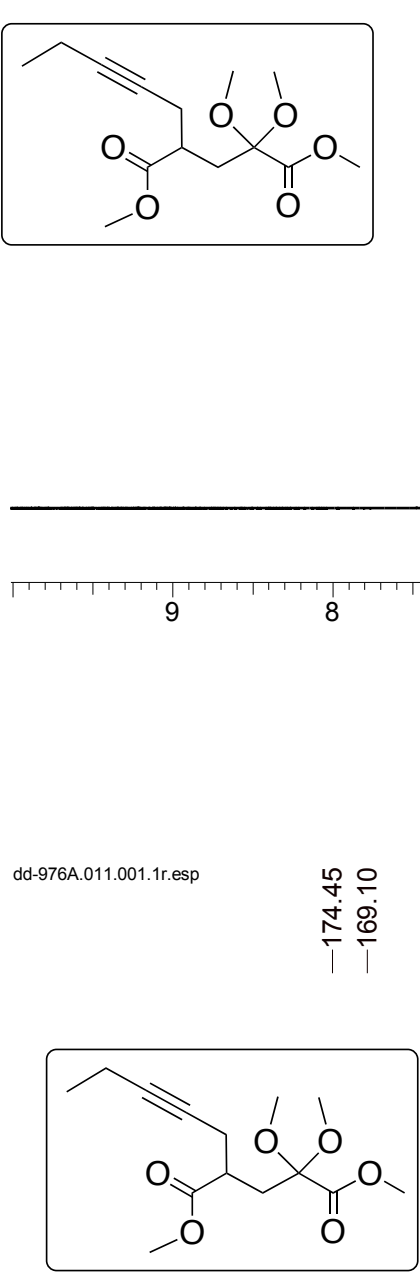

6 Chemical Shift (ppm)
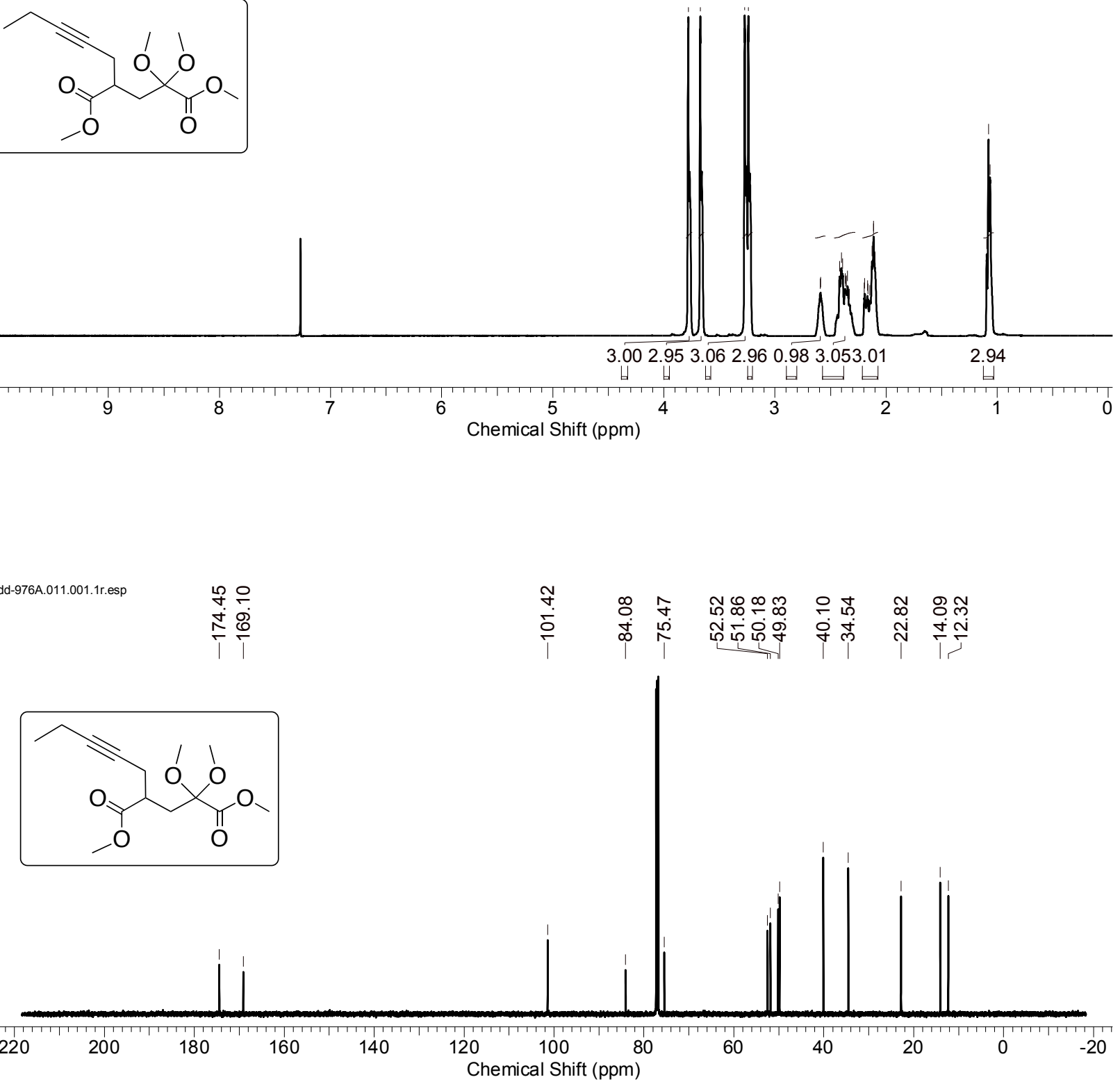

Supplementary Figure S23: ${ }^{1} \mathrm{H}$ and ${ }^{13} \mathrm{C}$ NMR spectrum of the boxed compound in $\mathrm{CDCl}_{3}$. 

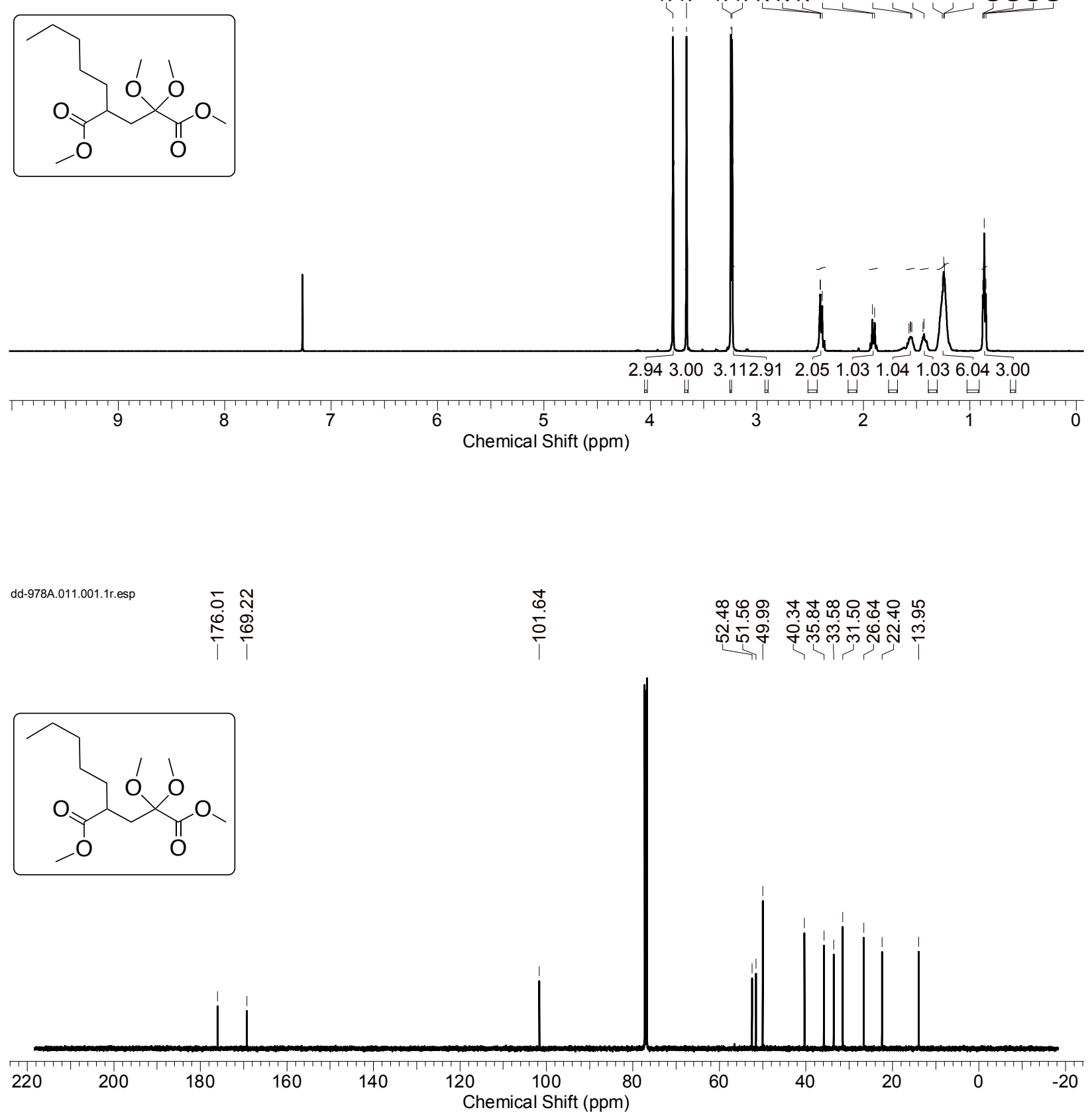

Supplementary Figure S24: ${ }^{1} \mathrm{H}$ and ${ }^{13} \mathrm{C}$ NMR spectrum of the boxed compound in $\mathrm{CDCl}_{3}$. 
dd-979A.010.001.1r.esp

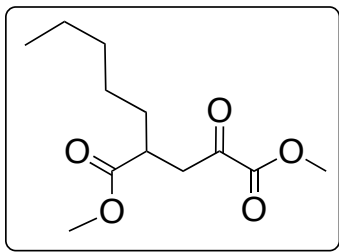

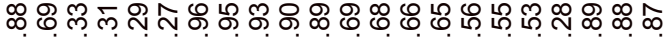

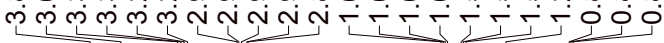

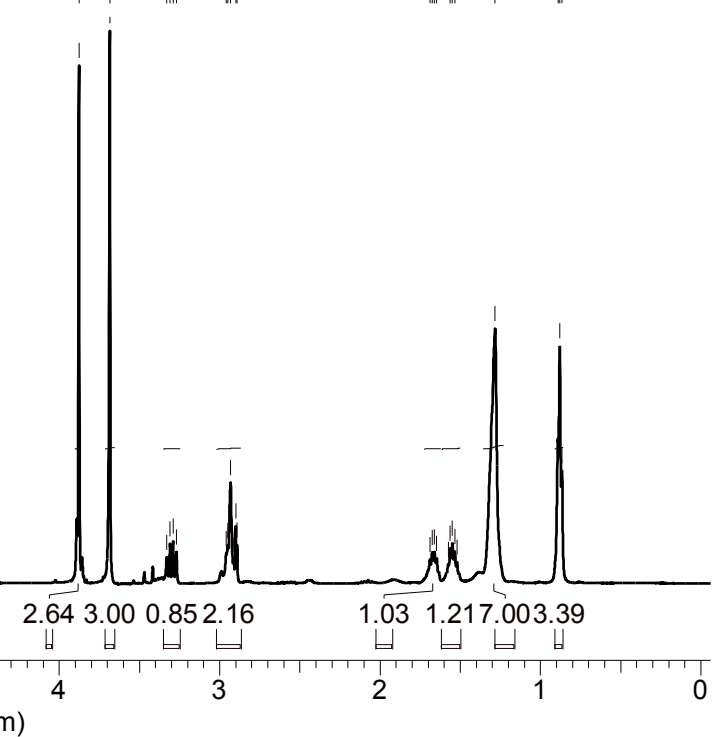

dd-979A.011.001.1r.esp co

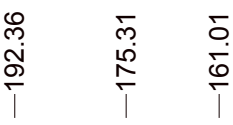

6 Chemical Shift (ppm)

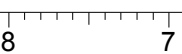

7
Chemical Shift (ppm)

$$
\text { (1) }
$$$$
\text { dd-979A.011.001.1r.esp e ల }
$$
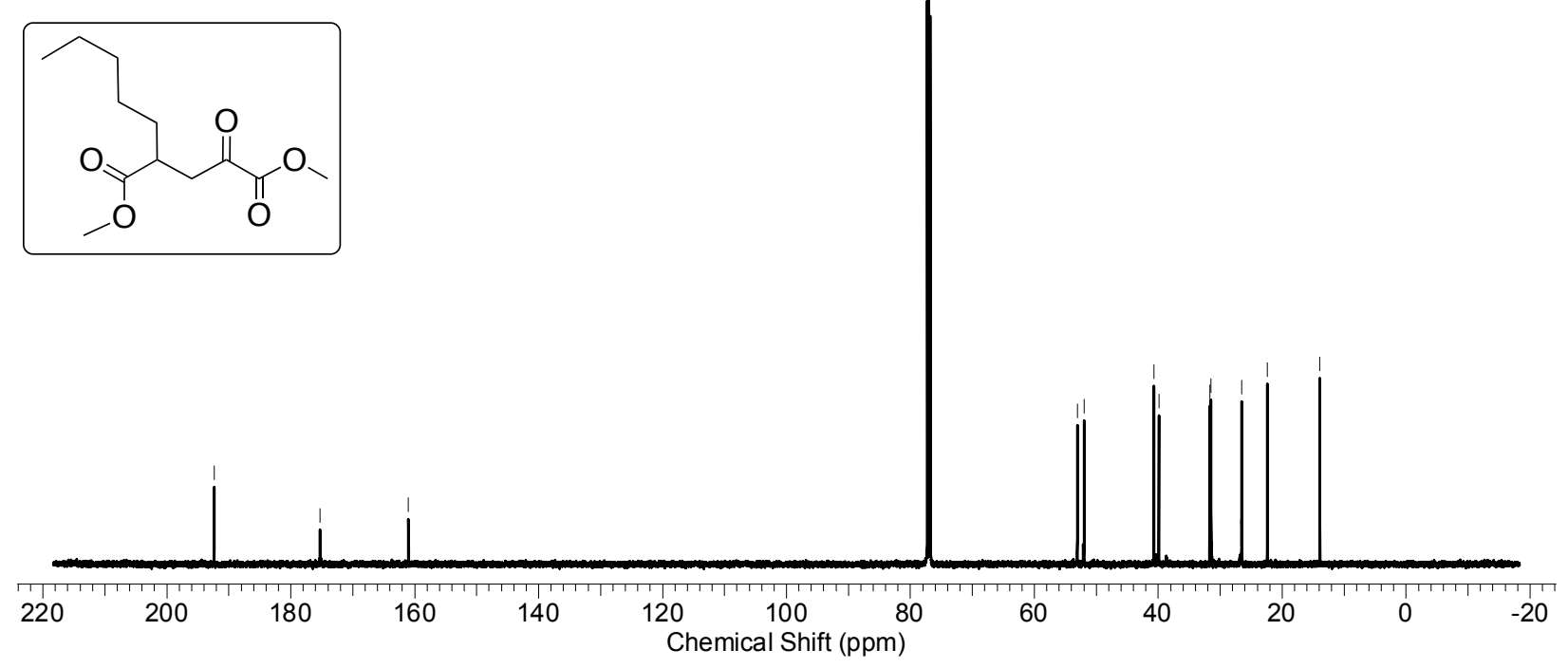

Supplementary Figure S25: ${ }^{1} \mathrm{H}$ and ${ }^{13} \mathrm{C}$ NMR spectrum of the boxed compound in $\mathrm{CDCl}_{3}$. 

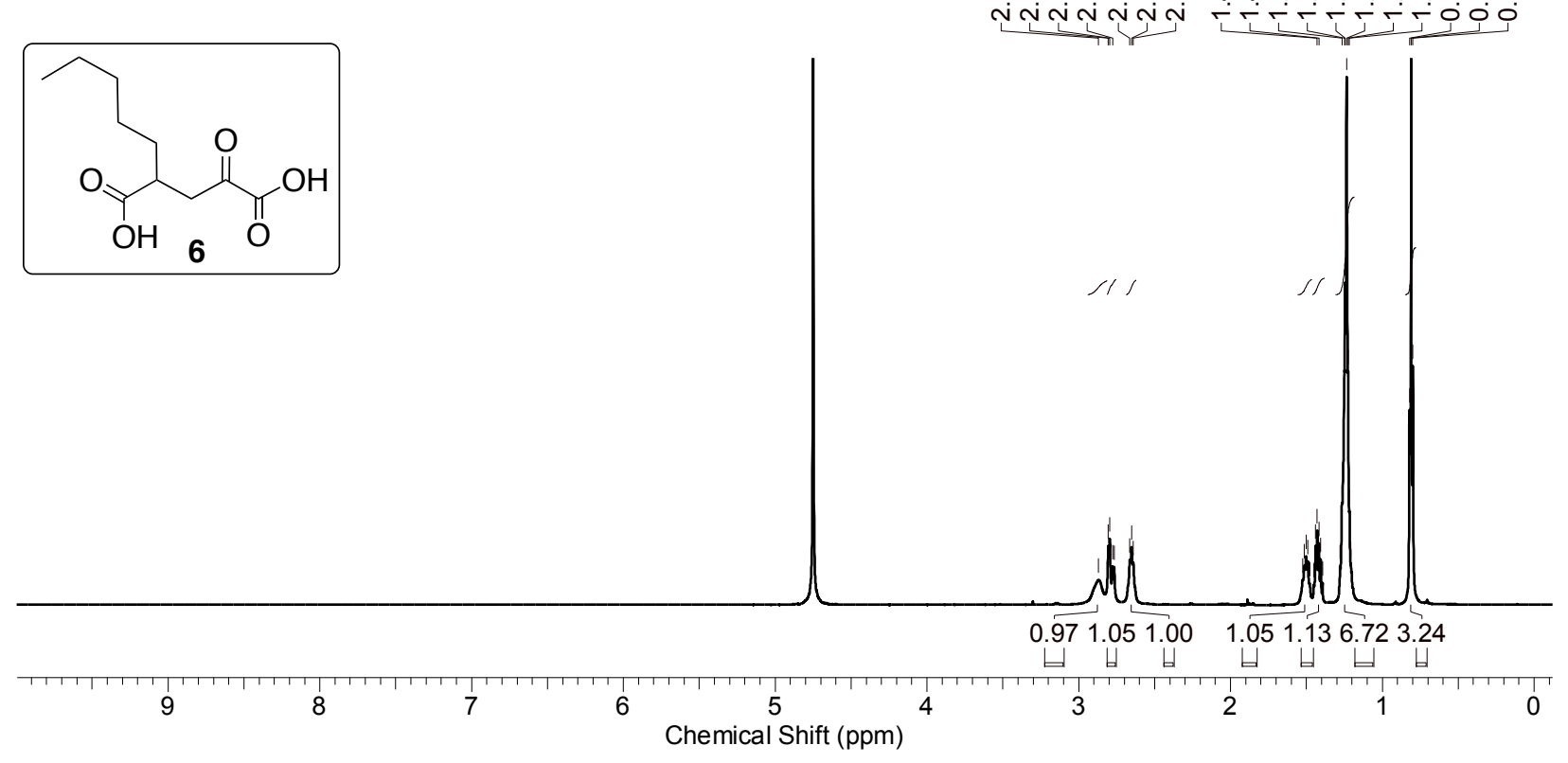

dd-979Ahydrol.002.001.1r.esp
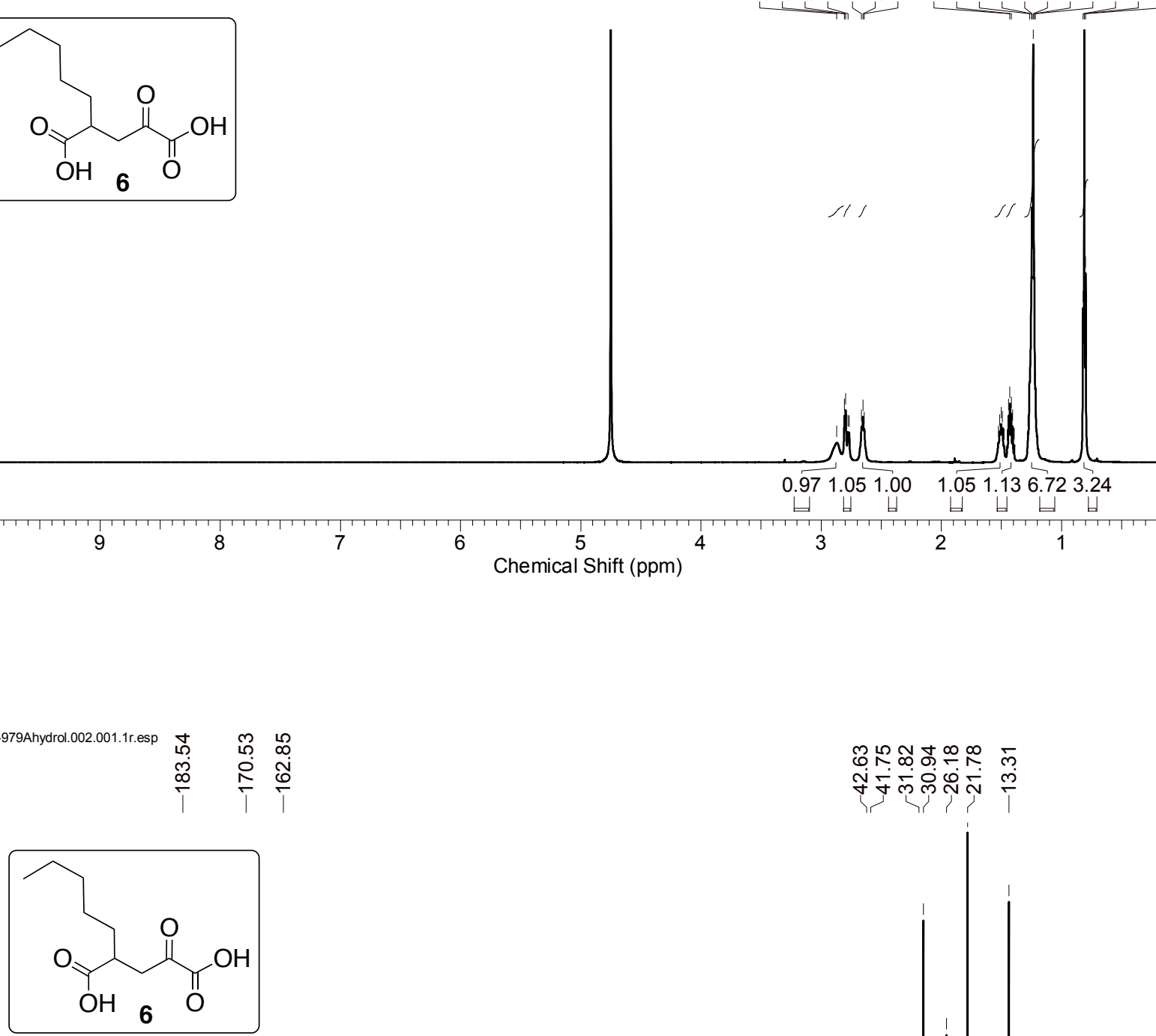


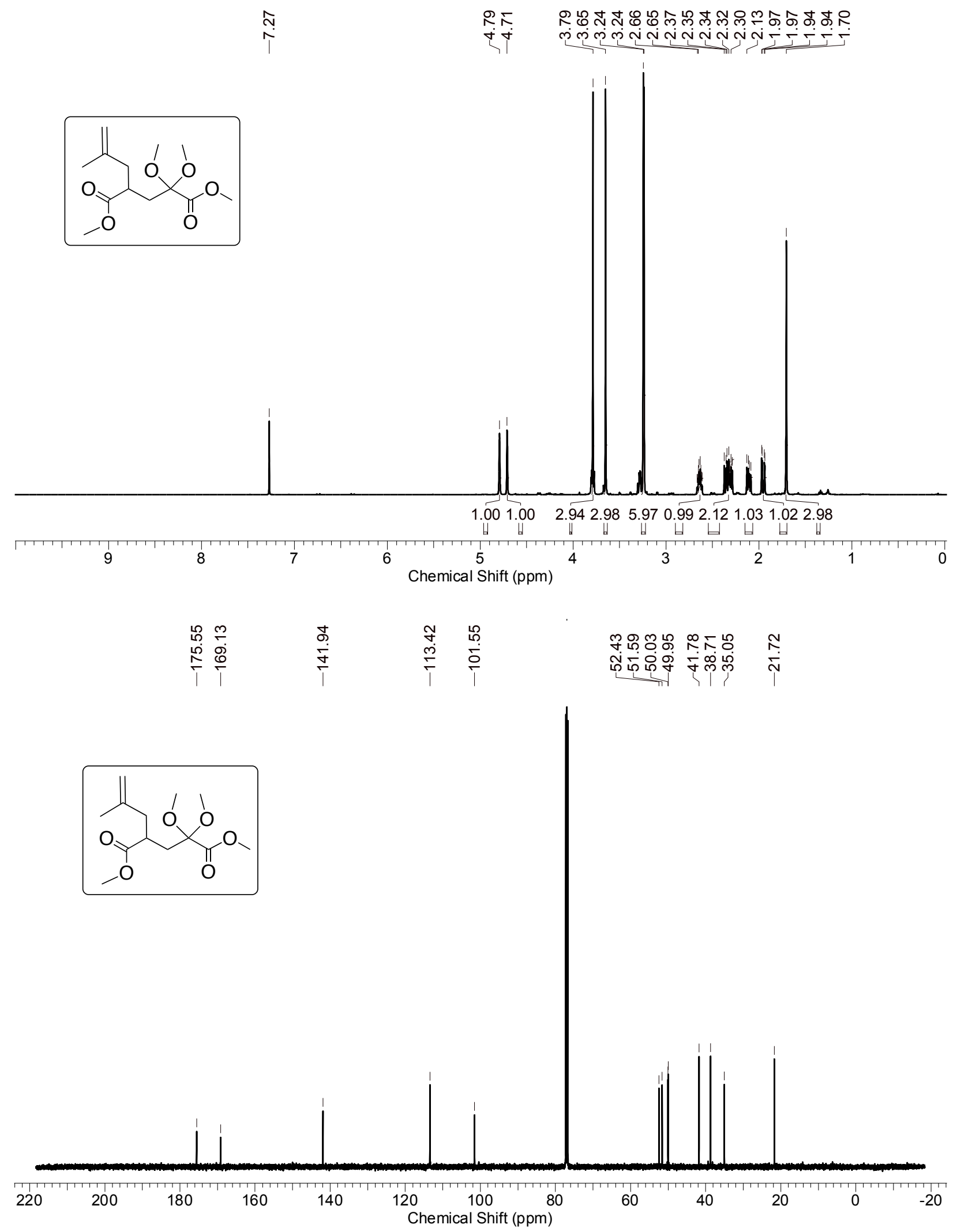

Supplementary Figure S27: ${ }^{1} \mathrm{H}$ and ${ }^{13} \mathrm{C}$ NMR spectrum of the boxed compound in $\mathrm{CDCl}_{3}$. 

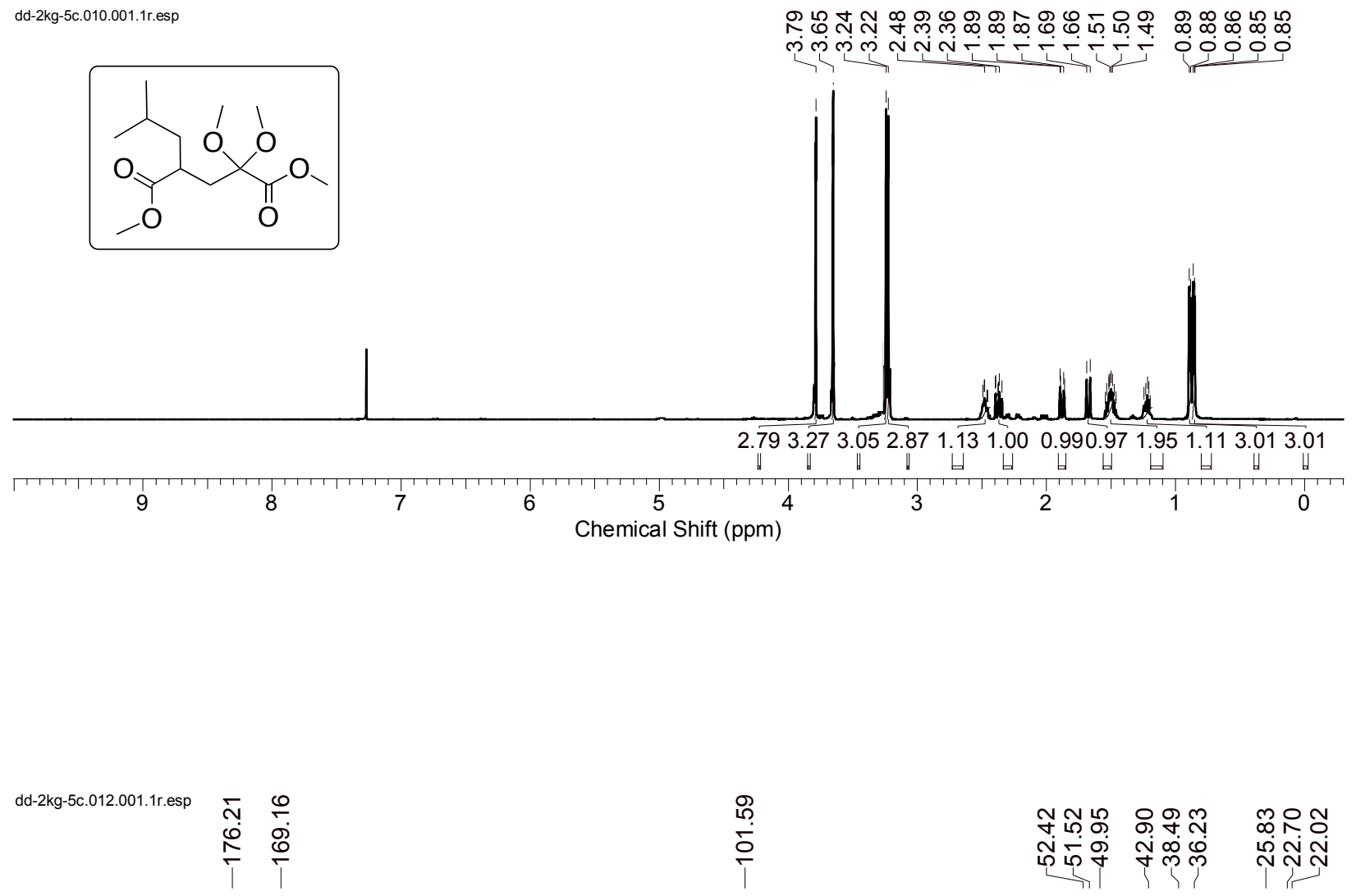<smiles>COC(=O)C(CC(C)C)CC(OC)(OC)C(=O)OC</smiles>

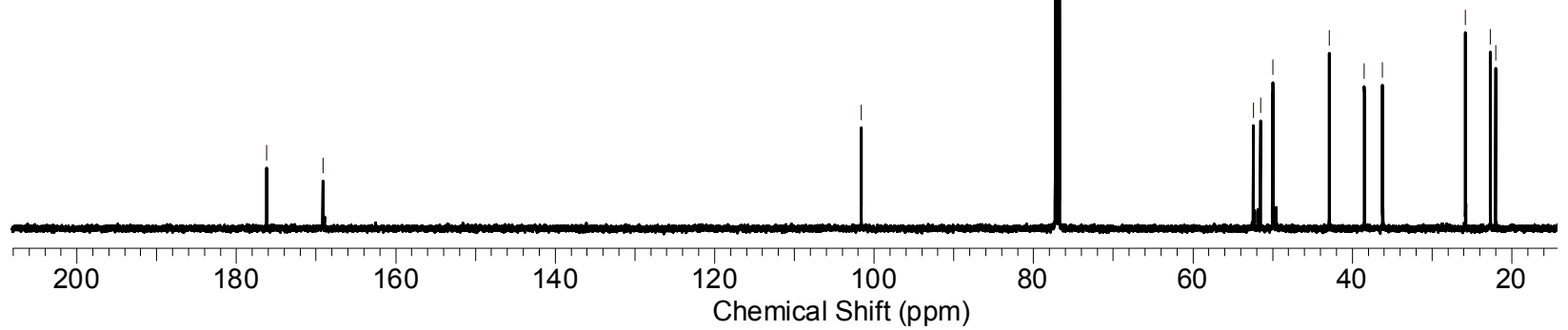

Supplementary Figure S28: ${ }^{1} \mathrm{H}$ and ${ }^{13} \mathrm{C}$ NMR spectrum of the boxed compound in $\mathrm{CDCl}_{3}$. 

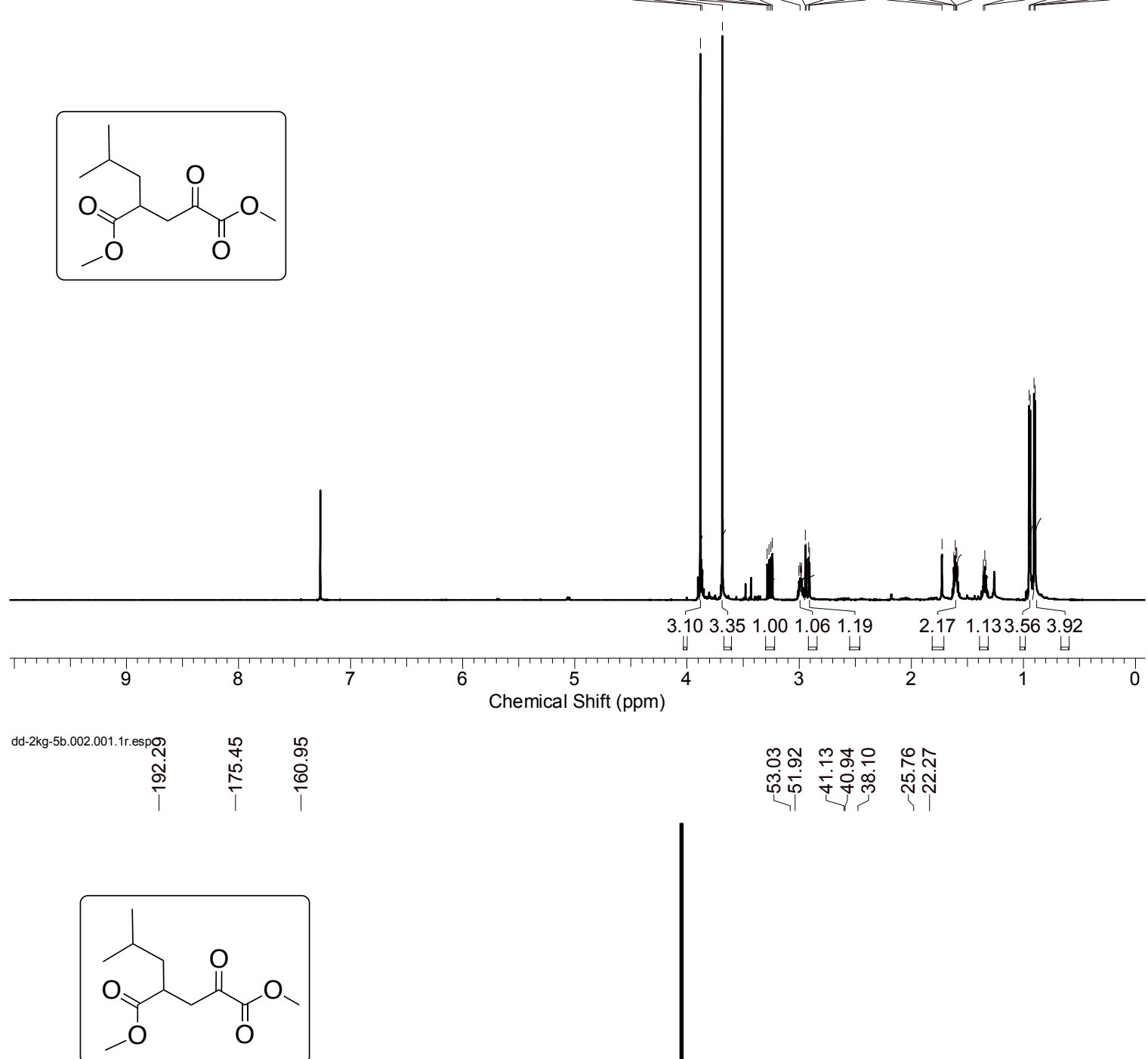

5
Chemical Shift (ppm)
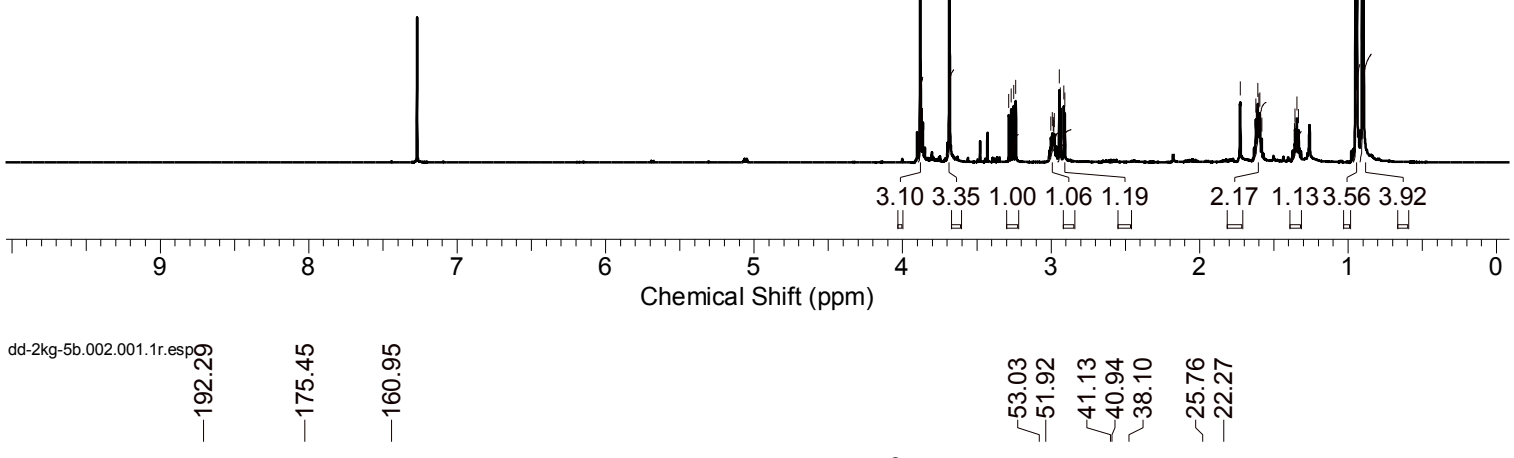

ก๊
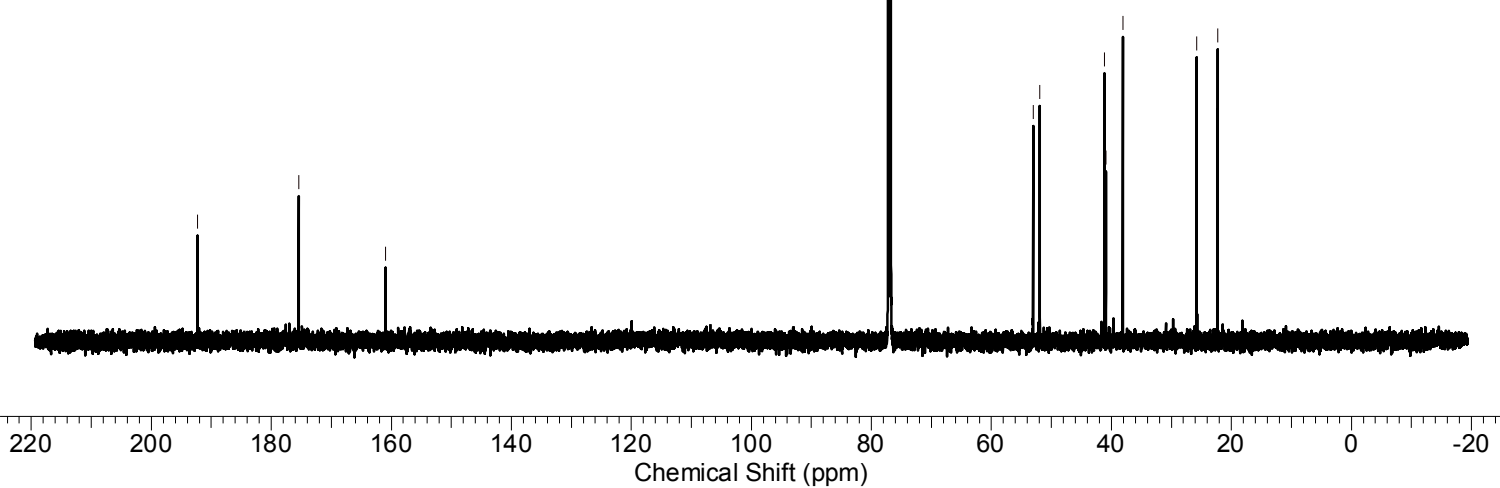

Supplementary Figure S29: ${ }^{1} \mathrm{H}$ and ${ }^{13} \mathrm{C}$ NMR spectrum of the boxed compound in $\mathrm{CDCl}_{3}$. 


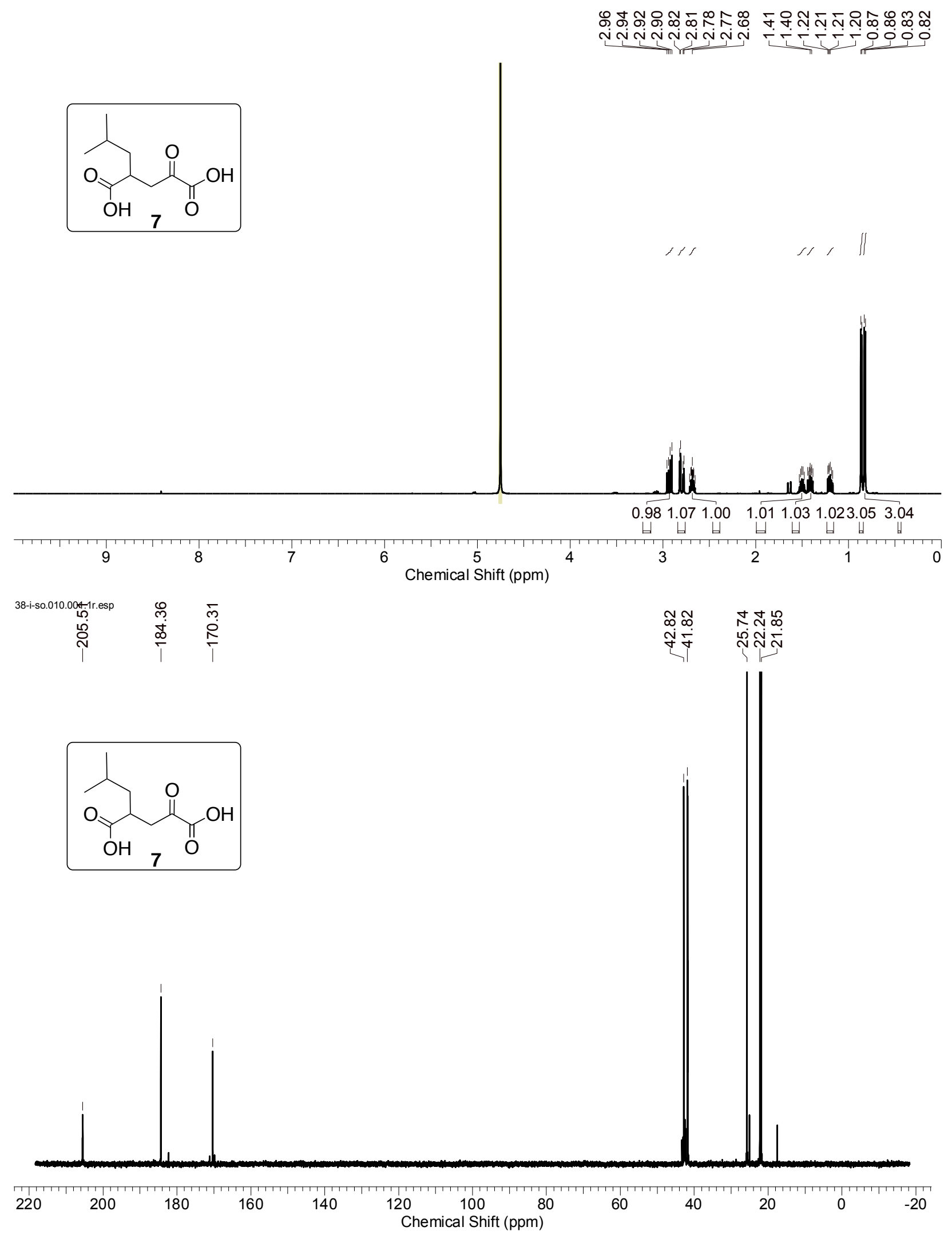

Supplementary Figure S30: ${ }^{1} \mathrm{H}$ and ${ }^{13} \mathrm{C}$ NMR spectrum of $2 \mathrm{KG}$ analogue 7 in $\mathrm{D}_{2} \mathrm{O}$. 

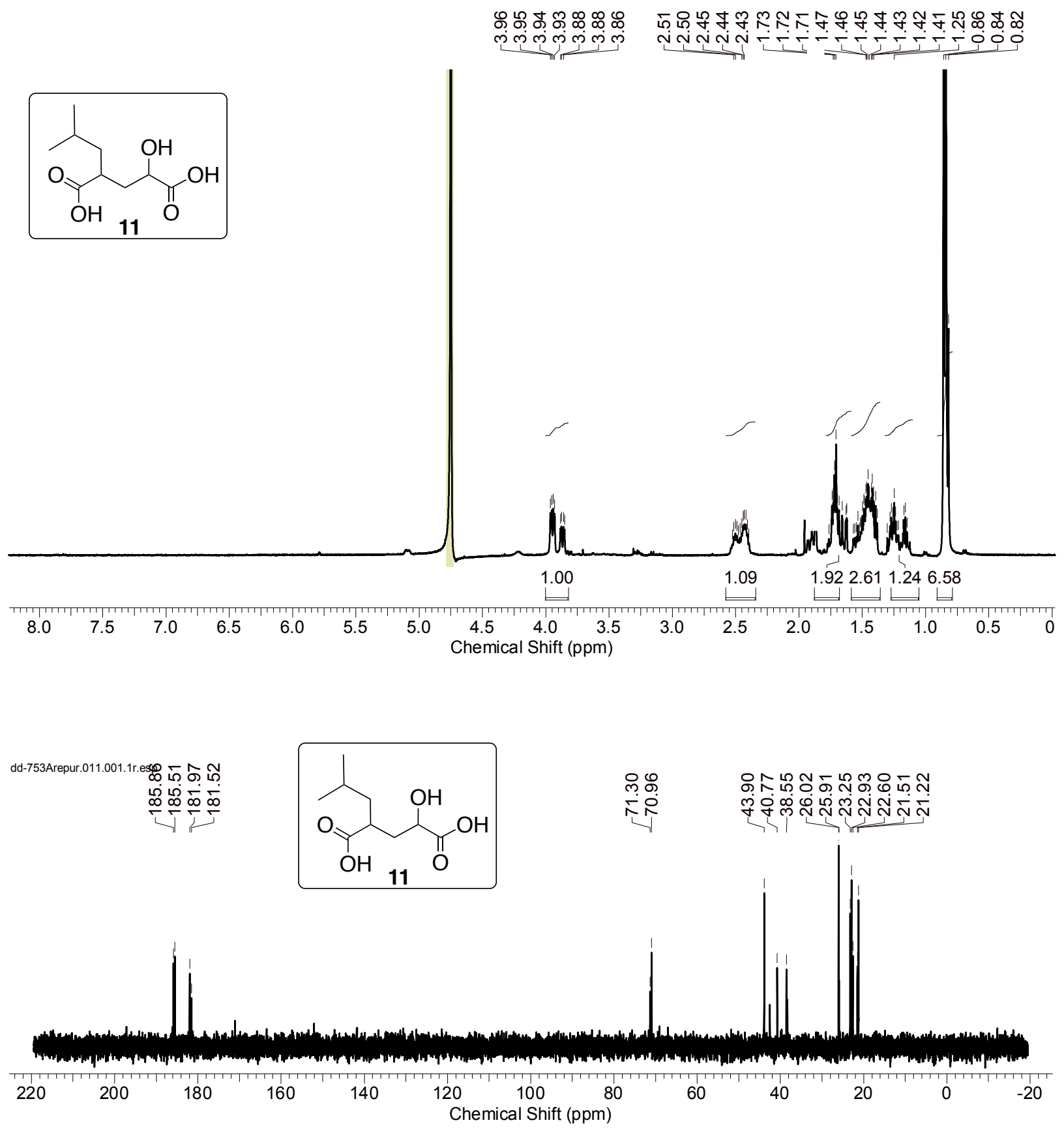

Supplementary Figure S31: ${ }^{1} \mathrm{H}$ and ${ }^{13} \mathrm{C}$ NMR spectrum of $2 \mathrm{HG}$ analogue 11 in $\mathrm{D}_{2} \mathrm{O}$. 


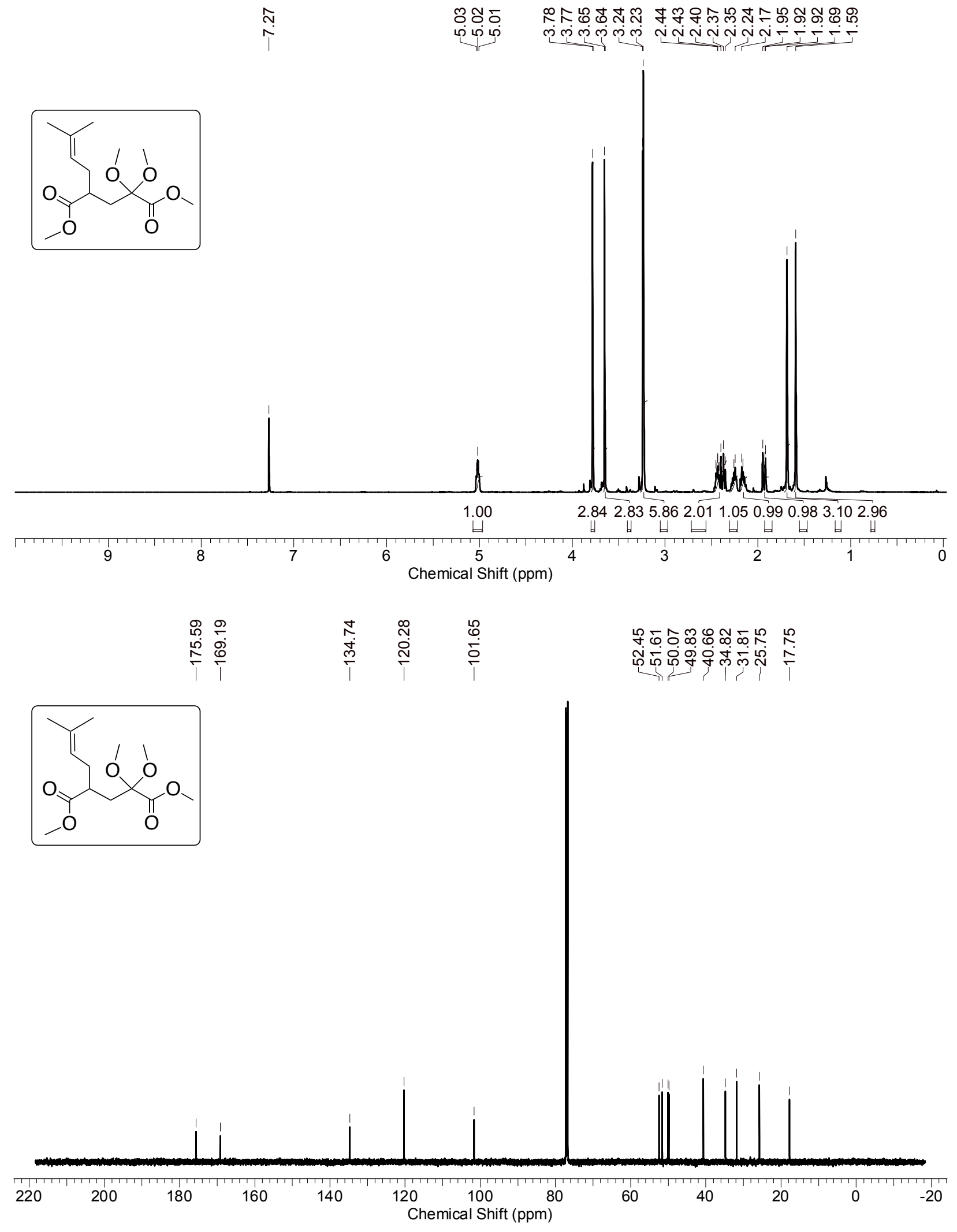

Supplementary Figure S32: ${ }^{1} \mathrm{H}$ and ${ }^{13} \mathrm{C}$ NMR spectrum of the boxed compound in $\mathrm{CDCl}_{3}$. 
dd-2kg-6c.010.001.1r.esp

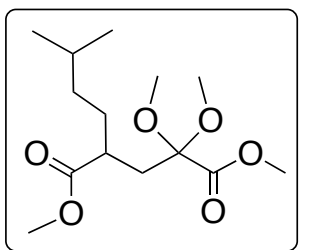

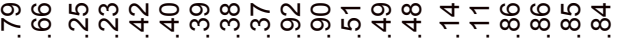

m

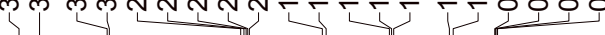
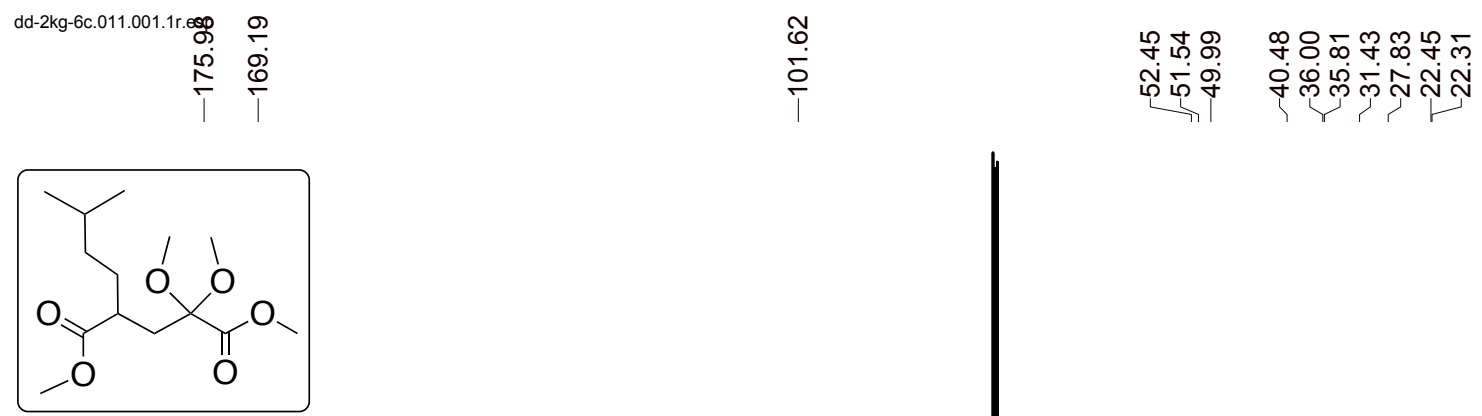

6

Shift (ppm)

$123.193 .133 .00 \quad 2.10 \quad 1.103 .362 .313 .293 .21$ $\|$ U
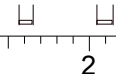

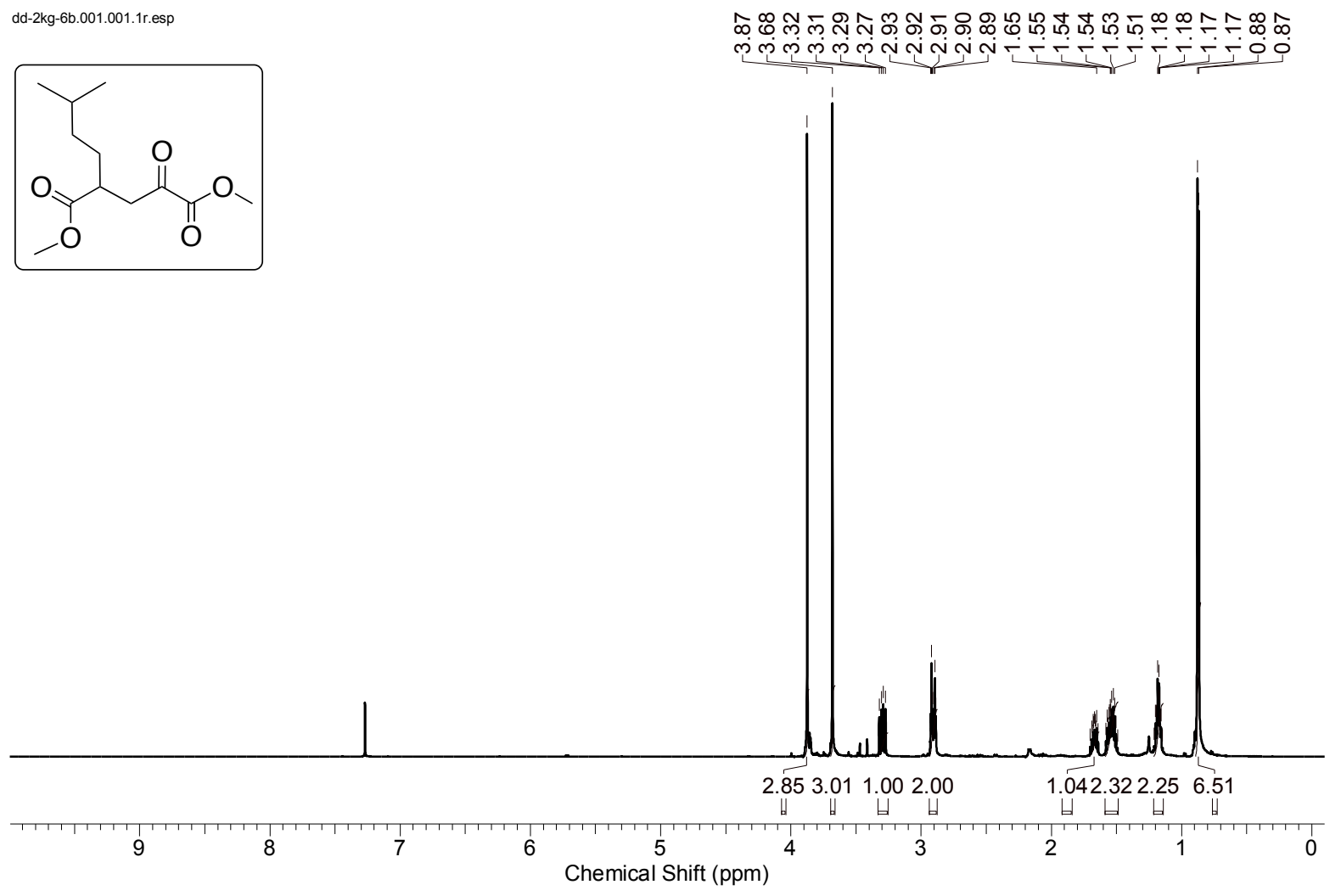

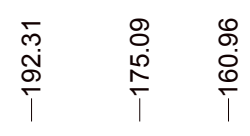

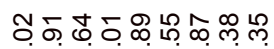

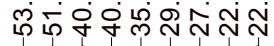
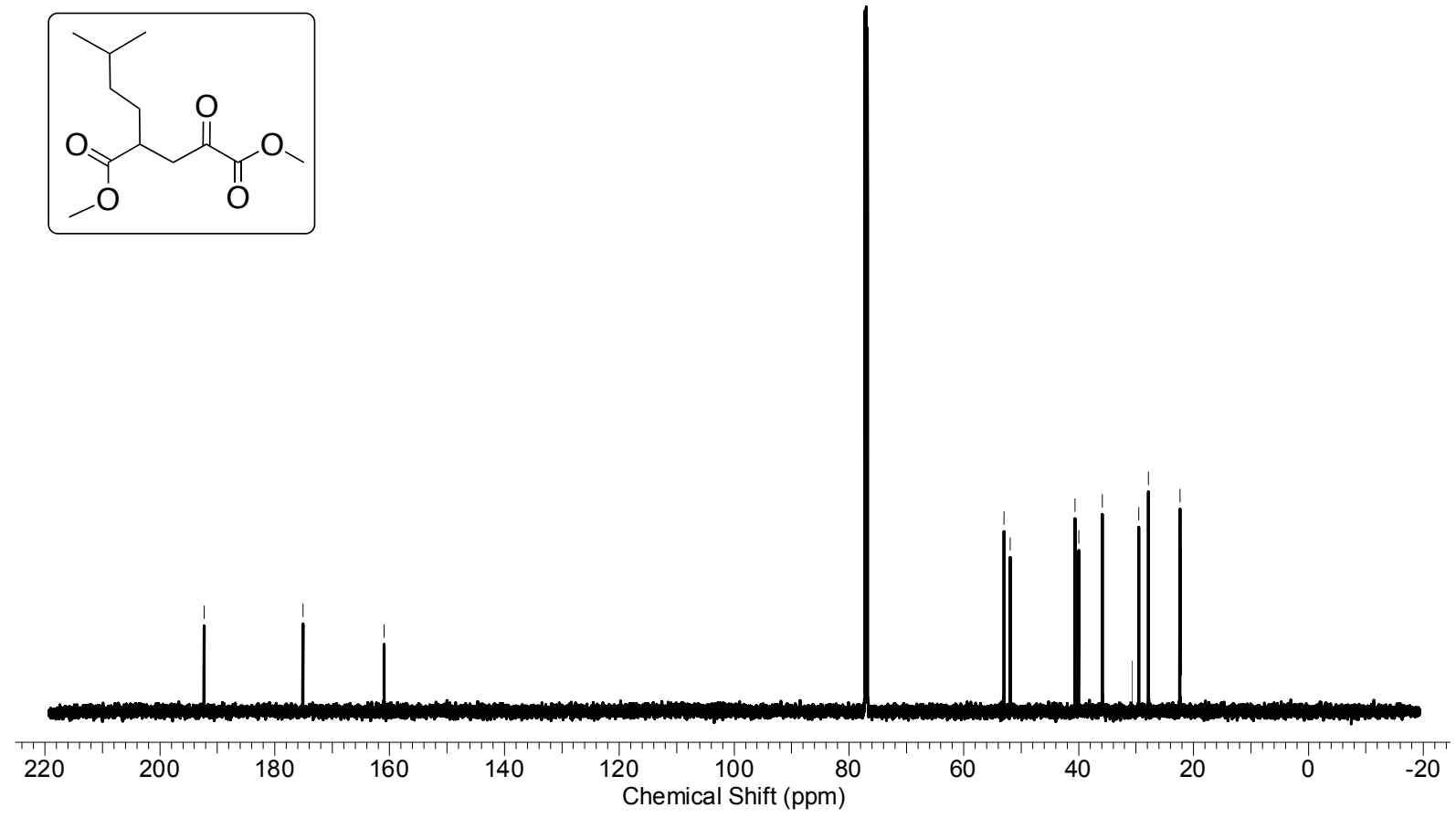

Supplementary Figure S34: ${ }^{1} \mathrm{H}$ and ${ }^{13} \mathrm{C}$ NMR spectrum of the boxed compound in $\mathrm{CDCl}_{3}$. 


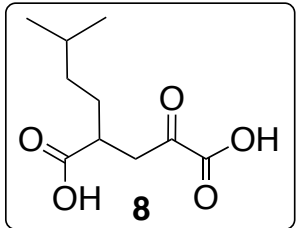
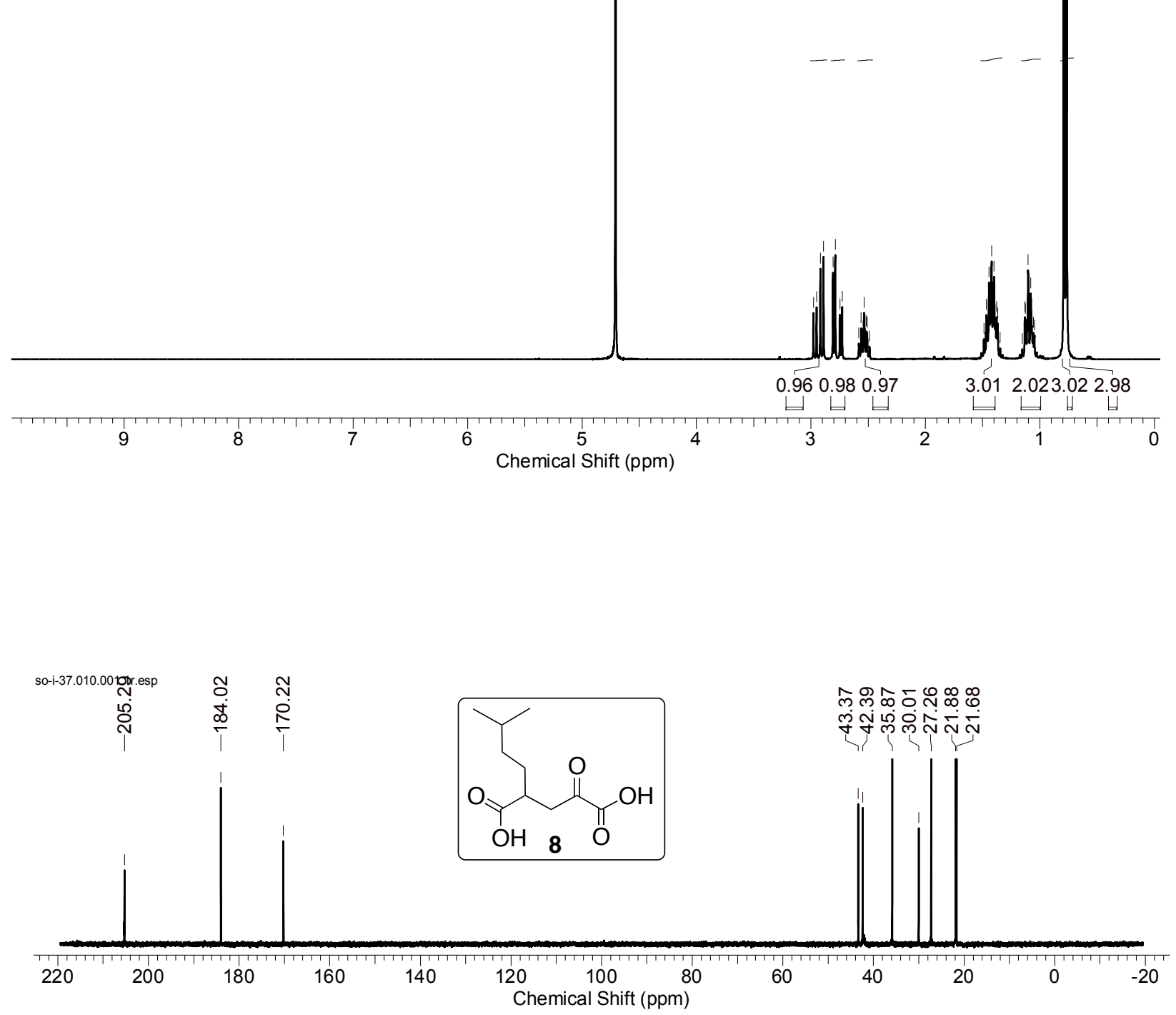

Supplementary Figure S35: ${ }^{1} \mathrm{H}$ and ${ }^{13} \mathrm{C}$ NMR spectrum of $2 \mathrm{KG}$ analogue 8 in $\mathrm{D}_{2} \mathrm{O}$. 


\begin{tabular}{|l|l|l|l|}
\hline GENE & VECTOR & AFFINITY TAG & RESISTANCE \\
\hline KDM4A & pNIC28-Bsa4 & N-6xHis & Kanamycin \\
\hline KDM4B & pST4 & N-strep(II) & Ampicillin \\
\hline KDM4C & pBh4 & N-6xHis & Ampicillin \\
\hline KDM4D & pST4 & N-strep(II) & Ampicillin \\
\hline HISTONE H3 & pET28 & None & Ampicillin \\
\hline KDM6B & pNH & N-6xHis & Kanamycin \\
\hline TET2 & pPEI-TET2 & C-6xHis & Kanamycin \\
\hline FTO & pET28a & N-6xHis & Kanamycin \\
\hline
\end{tabular}

Supplementary Table S1. List of the genes used in the current study. The expression vector, antibiotic resistance and the affinity tag present for protein purification are provided.

\begin{tabular}{|c|c|}
\hline MUTATION & FORWARD PRIMERS \\
\hline KDM4A-Y132A & 5'-CATTCAATCCTCCAATCGCCGGTGCAGATGTGAATGG-3' \\
\hline KDM4A-Y175A & 5'-GAGGGTGTGAACACCCCAGCCCTGTACTTTGGCATG-3' \\
\hline KDM4A-Y177A & 5'-GTGAACACCCATACCTGGCCTTTGGCATGTGGAAGAC-3' \\
\hline KDM4A-F185A & 5'-GGCATGTGGAAGACATCCGCCGCTTGGCACACTGAAGA-3' \\
\hline KDM4A-F185G & 5'-GGCATGTGGAAGACATCCGGCGCTTGGCACACTGAAG-3' \\
\hline KDM4A-F185I & 5'-GGCATGTGGAAGACATCCATCGCTTGGCACACTGAAG-3' \\
\hline KDM4A-F185T & 5'-GGCATGTGGAAGACATCCACCGCTTGGCACACTGAAG-3' \\
\hline KDM4A F185V & 5'-GGCATGTGGAAGACATCCGTGGCTTGGCACACTGAAG-3' \\
\hline KDM4A-N198A & 5'-GACCTCTACAGCATCGCCTACCTGCACTTTGG-3' \\
\hline KDM4A-K206A & 5'-CTGCACTTTGGAGAACCAGCCTCCTGGTACTCTGTTCC-3' \\
\hline KDM4A-W208A & 5'-CTTTGGAGAACCAAAGTCCGCCTACTCTGTTCCACCTGAG-3' \\
\hline KDM4A-S288A & 5'-GGTTTTAACTGTGCGGAGGCCACCAATTTTGGCTACCC-3' \\
\hline KDM4B-F186G & 5'-CATGTGGAAGACCACCGGCGCCTGGCACAC-3' \\
\hline KDM4C-F187G & 5'- GCATGTGGAAGACCACGGGCGCATGGCACACCGAAG-3' \\
\hline KDM4D-F189G & 5'- GCATGTGGAAAACCACGGGCGCTTGGCATACAGAG-3' \\
\hline $\mathrm{H} 3-\mathrm{K} 9 \mathrm{C}$ & 5'-GCAGACGGCTCGGTGCTCCACCGGCGG-3' \\
\hline
\end{tabular}

Supplementary Table S2. List of primers designed for site-directed mutagenesis. Reverse primers used are the reverse-complement to the given forward primers. 


\begin{tabular}{|l|l|}
\hline \multicolumn{1}{|c|}{ PROTEINS } & \multicolumn{1}{c|}{ BACTERIAL CELLS FOR EXPRESSION } \\
\hline KDM4A-WT & BL21 [DE3] pLysS \\
\hline KDM4A-Y132A & BL21 [DE3] pLysS \\
\hline KDM4A-Y175A & BL21 [DE3] pLysS \\
\hline KDM4A-Y177A & BL21 [DE3] pLysS \\
\hline KDM4A-F185A & BL21 [DE3] pLysS \\
\hline KDM4A-F185G & BL21 [DE3] Codon plus \\
\hline KDM4A-F185I & BL21 [DE3] Arctic Express \\
\hline KDM4A-F185T & BL21 [DE3] Arctic Express \\
\hline KDM4A-F185V & BL21 [DE3] Arctic Express \\
\hline KDM4A-N198A & BL21 [DE3] Codon plus \\
\hline KDM4A-K206A & BL21 [DE3] pLysS \\
\hline KDM4A-W208A & BL21 [DE3] pLysS \\
\hline KDM4A-S288A & BL21 [DE3] Codon plus \\
\hline KDM4B-WT & BL21 [DE3] Codon plus \\
\hline KDM4B-F186G & BL21 [DE3] Star \\
\hline KDM4C-WT & BL21 [DE3] Star \\
\hline KDM4C-F187G & BL21 [DE3] Star \\
\hline KDM4D-WT & Rosetta [DE3] pLysS \\
\hline KDM4D-F189G & BL21 [DE3] Codon plus \\
\hline FTO-WT & BL21 [DE3] Codon plus \\
\hline TET2-WT & BL21 [DE3] Codon plus \\
\hline KDM6B-WT & Rosetta [DE3] pLysS \\
\hline Histone H3-WT & BL21 codon plus (DE3) RIPL \\
\hline H3-K9C & BL21 codon plus (DE3) RIPL \\
\hline & \\
\hline
\end{tabular}

Supplementary Table S3. List of competent bacterial cells used in the current study for the expression of indicated proteins. 


\begin{tabular}{|c|c|c|}
\hline PEPTIDES & SEQUENCE & MW (Da) \\
\hline $\mathrm{H}_{3} 3 \mathrm{KMe}_{3}$ & $\mathrm{H}_{2} \mathrm{~N}-\mathrm{ARTK}\left(\mathrm{Me}_{3}\right) \mathrm{QTARKSTGGKAPRKQLK}$ (biotin)- $\mathrm{CO}_{2} \mathrm{H}$ & 2692 \\
\hline $\mathrm{H}_{3} \mathrm{~K} \mathrm{Me}_{3}$ & $\mathrm{H}_{2} \mathrm{~N}-\mathrm{ARTKQTARK}\left(\mathrm{Me}_{3}\right)$ STGGKAPRKQLK(biotin)-CONH ${ }_{2}$ & 2693 \\
\hline $\mathrm{H} 3 \mathrm{~K} 27 \mathrm{Me}_{3}$ & $\mathrm{H}_{2} \mathrm{~N}-\mathrm{APRKQLATKAARK}\left(\mathrm{Me}_{3}\right)$ SAPATGGVK(biotin)-CONH ${ }_{2}$ & 2475 \\
\hline $\mathrm{H} 3 \mathrm{~K}_{3} 6 \mathrm{Me}_{3}$ & $\mathrm{H}_{2} \mathrm{~N}-\mathrm{KSAPSTGGVK}\left(\mathrm{Me}_{3}\right)$ KPHRYKPGTGK(biotin)-CONH${ }_{2}$ & 2562 \\
\hline $\mathrm{H} 3 \mathrm{R}_{2} \mathrm{Me}_{2}$ & $\mathrm{H}_{2} \mathrm{~N}-\mathrm{AR}\left(\mathrm{Me}_{2}\right)$ TKQTARKSTGGKAPRKK(biotin)-CONH${ }_{2}$ & 2195 \\
\hline OLIGONUCLEOTIDES & SEQUENCE & MW (Da) \\
\hline 5mC-DNA & $\begin{array}{l}\text { 5'-CAC5mCGGTG-3' and 5'-CAC5mCGGTG-3' (Identical } \\
\text { palindromic sequences) }\end{array}$ & 2424 \\
\hline m6A-RNA & 5'-CUGGm6ACUGG-3' & $\begin{array}{l}2963 \text { (Observed } 2883 \\
\text { due to the loss of } \\
\text { phosphoric acid }\end{array}$ \\
\hline
\end{tabular}

Supplementary Table S4. List of methylated peptides, DNA and RNA used in the current study as substrates of histone, DNA and RNA demethylases. For DNA demethylase TET2, palindromic sequences were annealed prior to the demethylation assay.

\section{References}

(1) Helaine, V.; Bolte, J. Eur. J. Org. Chem. 1999, 1999, 3403.

(2) Dai, Q.; Fong, R.; Saikia, M.; Stephenson, D.; Yu, Y. T.; Pan, T.; Piccirilli, J. A. Nucleic Acids Res. 2007, 35, 6322.

(3) Krishnan, S.; Trievel, R. C. Structure 2013, 21, 98.

(4) Krishnan, S.; Collazo, E.; Ortiz-Tello, P. A.; Trievel, R. C. Anal. Biochem. 2012, 420, 48.

(5) Pack, L. R.; Yamamoto, K. R.; Fujimori, D. G. J. Biol. Chem. 2016, 291, 6060.

(6) Williams, S. T.; Walport, L. J.; Hopkinson, R. J.; Madden, S. K.; Chowdhury, R.; Schofield, C. J.; Kawamura, A. Epigenetics 2014, 9, 1596.

(7) Fu, Y.; Jia, G.; Pang, X.; Wang, R. N.; Wang, X.; Li, C. J.; Smemo, S.; Dai, Q.; Bailey, K. A.; Nobrega, M. A.; Han, K. L.; Cui, Q.; He, C. Nat. Commun. 2013, 4, 1798.

(8) Hu, L.; Li, Z.; Cheng, J.; Rao, Q.; Gong, W.; Liu, M.; Shi, Y. G.; Zhu, J.; Wang, P.; Xu, Y. Cell 2013, 155, 1545 .

(9) Roy, T. W.; Bhagwat, A. S. Nucleic Acids Res. 2007, 35, e147.

(10) Xu, W.; Yang, H.; Liu, Y.; Yang, Y.; Wang, P.; Kim, S. H.; Ito, S.; Yang, C.; Wang, P.; Xiao, M. T.; Liu, L. X.; Jiang, W. Q.; Liu, J.; Zhang, J. Y.; Wang, B.; Frye, S.; Zhang, Y.; Xu, Y. H.; Lei, Q. Y.; Guan, K. L.; Zhao, S. M.; Xiong, Y. Cancer Cell 2011, 19, 17. 
(11) Simon, M. D.; Chu, F.; Racki, L. R.; de la Cruz, C. C.; Burlingame, A. L.; Panning, B.; Narlikar, G. J.; Shokat, K. M. Cell 2007, 128, 1003.

(12) Simon, M. D. Curr. Protoc. Mol. Biol. 2010, Chapter 21, Unit 21.18.1.

(13) Hopkinson, R. J.; Tumber, A.; Yapp, C.; Chowdhury, R.; Aik, W.; Che, K. H.; Li, X. S.; Kristensen, J. B.; King, O. N.; Chan, M. C.; Yeoh, K. K.; Choi, H.; Walport, L. J.; Thinnes, C. C.; Bush, J. T.; Lejeune, C.; Rydzik, A. M.; Rose, N. R.; Bagg, E. A.; McDonough, M. A.; Krojer, T.; Yue, W. W.; Ng, S. S.; Olsen, L.; Brennan, P. E.; Oppermann, U.; Muller-Knapp, S.; Klose, R. J.; Ratcliffe, P. J.; Schofield, C. J.; Kawamura, A. Chem. Sci. 2013, 4, 3110.

(14) King, O. N.; Li, X. S.; Sakurai, M.; Kawamura, A.; Rose, N. R.; Ng, S. S.; Quinn, A. M.; Rai, G.; Mott, B. T.; Beswick, P.; Klose, R. J.; Oppermann, U.; Jadhav, A.; Heightman, T. D.; Maloney, D. J.; Schofield, C. J.; Simeonov, A. PloS One 2010, 5, e15535.

(15) Johansson, C.; Tumber, A.; Che, K.; Cain, P.; Nowak, R.; Gileadi, C.; Oppermann, U. Epigenomics 2014, 6, 89.

(16) Guerra-Calderas, L.; Gonzalez-Barrios, R.; Herrera, L. A.; Cantu de Leon, D.; Soto-Reyes, E. Cancer Genet. 2015, 208, 215.

\section{Expanded references in the manuscript:}

(8) Das, P. P.; Shao, Z.; Beyaz, S.; Apostolou, E.; Pinello, L.; De Los Angeles, A.; O'Brien, K.; Atsma, J.

M.; Fujiwara, Y.; Nguyen, M.; Ljuboja, D.; Guo, G.; Woo, A.; Yuan, G. C.; Onder, T.; Daley, G.;

Hochedlinger, K.; Kim, J.; Orkin, S. H. Mol. Cell 2014, 53, 32.

(22) Xu, W.; Yang, H.; Liu, Y.; Yang, Y.; Wang, P.; Kim, S. H.; Ito, S.; Yang, C.; Wang, P.; Xiao, M. T.; Liu, L. X.; Jiang, W. Q.; Liu, J.; Zhang, J. Y.; Wang, B.; Frye, S.; Zhang, Y.; Xu, Y. H.; Lei, Q. Y.; Guan, K. L.; Zhao, S. M.; Xiong, Y. Cancer Cell 2011, 19, 17.

(23) Chowdhury, R.; Yeoh, K. K.; Tian, Y. M.; Hillringhaus, L.; Bagg, E. A.; Rose, N. R.; Leung, I. K.; Li, X. S.; Woon, E. C.; Yang, M.; McDonough, M. A.; King, O. N.; Clifton, I. J.; Klose, R. J.; Claridge, T. D.; Ratcliffe, P. J.; Schofield, C. J.; Kawamura, A. EMBO Report. 2011, 12, 463.

(25) Hopkinson, R. J.; Tumber, A.; Yapp, C.; Chowdhury, R.; Aik, W.; Che, K. H.; Li, X. S.; Kristensen, J. B.; King, O. N.; Chan, M. C.; Yeoh, K. K.; Choi, H.; Walport, L. J.; Thinnes, C. C.; Bush, J. T.; Lejeune, C.; Rydzik, A. M.; Rose, N. R.; Bagg, E. A.; McDonough, M. A.; Krojer, T.; Yue, W. W.; Ng, 
S. S.; Olsen, L.; Brennan, P. E.; Oppermann, U.; Muller-Knapp, S.; Klose, R. J.; Ratcliffe, P. J.; Schofield, C. J.; Kawamura, A. Chem. Sci. 2013, 4, 3110. 